
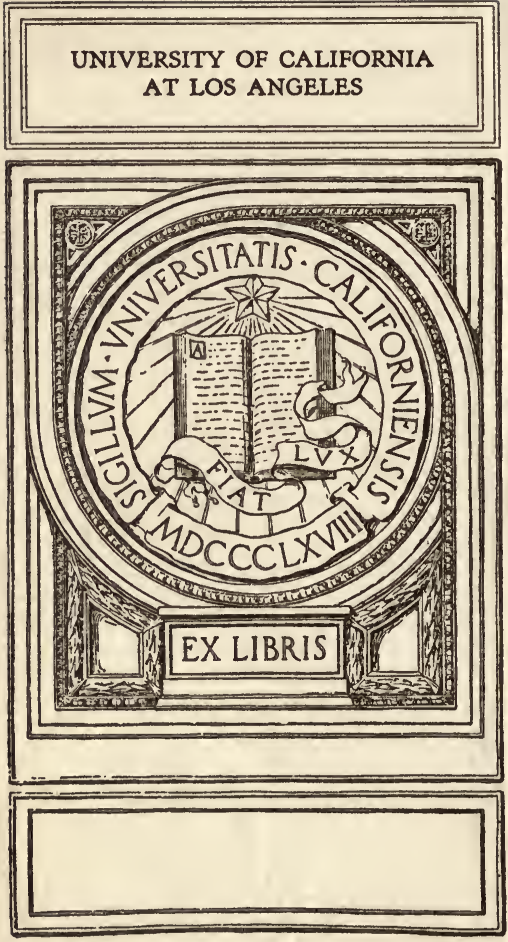





\section{THE MASON-WASPS}

\section{$4 \overline{963}$}




\section{BOOKS BY J. HENRI FABRE}

THE LIFE OF THE SPIDER THE LIFE OF THE FLY THE MASON-BEES BRAMBLE-BEES AND OTHERS THE HUNTING WASPS THE LIFE OF THE CATERPILLAR THE LIFE OF THE GRASSHOPPER

THE SACRED BEETLE AND OTHERS THE MASON-WASPS 


\section{THE MASON-WASPS}

BY

J. HENRI FABRE

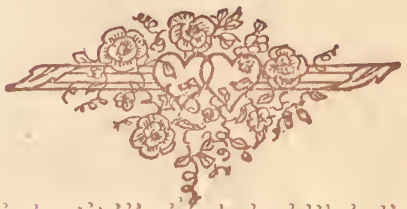

TRANSLATED BY

Alexander TEIXEIRA DE MATtOS

FELLOW OF THB ZOOLOGICAL SOCIETY OF LONDON

NEW YORK

DODD, MEAD AND COMPANY

1919

39737 
COPYRight, 1919

BY DODD, MEAD AND COMPANY, INO.

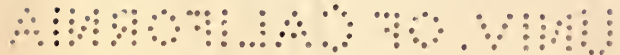

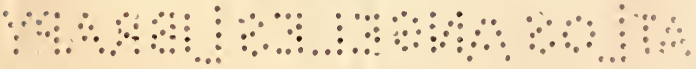




\section{$Q L$
568 \\ V5FIIm}

\section{CON'TENTS}

PAGE

TRANSLATOR'S NOTE . . . . V V CHAPTER

I THE EUMENES • . . . . I

II THE ODYNERI . . . . . . 28

III THE PELOPIEUS . . . . . 60

IV THE AGENIA; THE PELOP EUS'

VICTUALS . . . . . . 84

V ABERRATIONS OF INSTINCT • . IO6

VI THE SWALLOW AND THE SPARROW I33

VII INSTINCT AND DISCERNMENT . I 55

VIII THE NEST-BUILDING ODYNERUS . I76

IX INSECT GEOMETRY • . • . • 2 I9

X THE COMMON WASP . . . . 240

XI THE COMMON WASP (continued) 270

XII THE VOLUCELLA . . . . . 288 INDEX.$\quad \cdot \quad \cdot \quad \cdot \quad \cdot 3 I 3$ 



\section{TRANSLATOR'S NOTE}

This is the second volume on Wasps in the Collected Edition of Fabre's Souvenirs entomologiques. The first of these was The Hunting Wasps; and the present volume is somewhat wilfully entitled, for all Wasps hunt in varying degrees, if not on their own behalf, at least on that of their young. My object, however, was to bring together all the essays treating of those Wasps who actually build homes or nests, as distinct from burrows. The last book on Wasps will be called More Hunting Wasps and will be issued towards the end of the series.

For reasons which will be easily apparent to the reader, I have reprinted the chapter called Instinct and Discernment, which was included in Bramble-bees and Others, and that on the Volucella, which, under the title of The Bumble-bee Fly, formed part of The Life of the Fly. Apart from the two chapters named and the essay on the Eumenes, which figures in The Wonders of Instinct, published in America by the Century Co., 


\section{Translator's Note}

none of the contents of this volume has until now appeared in the English language. The $V$ olucella is included by arrangement with Mr. Fisher Unwin, the publisher of The Wonders of Instinct in England.

My thanks are due to the late Miss Frances Rodwell and to my friend Bernard Miall, both of whom have been of great assistance to me in preparing my translation.

Alexander Teixeira de Mattos. CHELSEA, I 8 April, I9I9. 
THE MASON-WASPS 



\section{CHAPTER I}

\section{THE EUMENES}

A WASP-LIKE garb of black and yelA low; a slender, graceful figure; wings that are not spread flat when resting, but are folded lengthwise in two; the abdomen a sort of chemist's retort, swelling into a gourd and fastened to the thorax by a long neck which first distends into a pear and then shrinks to a thread; a leisurely and silent flight; lonely habits. There we have a summary sketch of the Eumenes. My part of the country possesses two species: the larger $E$. Amadei, LEP., measures nearly an inch in length; the other, E. pomiformis, FABR., ${ }^{1}$ is a reduction of the first to half the scale.

Similar in form and colouring, both possess a like talent for architecture; and this

1 I include three species promiscuously under this one name, that is to say, $E$. pomiformis, FABR., E. bipunctis, SAUss., and $E$. dubius, SaUss. As I did not distinguish between them in my first investigations, which date a very long time back, it is not possible for me to-day to attribute to each of them its respective nest. But their habits are the same, for which reason this confusion does not injure the order of ideas in the present chapter.-Author's Note. 


\section{The Mason-Wasps}

talent is expressed in a work of the highest perfection, which charms the most untutored eye. Their dwelling is a masterpiece. And yet the Eumenes follow the profession of arms, which is unfavourable to artistic effort: they stab and sting a victim; they pillage and plunder. They are predatory Wasps, victualling their larvæ with caterpillars. It must be interesting to compare their habits with those of the operator on the Grey Worm. ${ }^{1}$ Though the quarry - caterpillars in either case - remain the same, instinct, which is liable to vary with the species, may have fresh glimpses in store for us. Besides, the edifice built by the Eumenes in itself deserves inspection.

The Hunting Wasps whose story we have told hitherto ${ }^{2}$ are wonderfully well-versed in the art of wielding the lancet; they astound us with their surgical methods, which they

1 The Grey Worm is the caterpillar of Noctua segetum, the Dart or Turnip Moth. It is hunted by the Hairy Ammophila, for whom cf. The Hunting $W$ asps, by J: Henri Fabre, translated by Alexander Teixeira de Mattos: chap. xviii.-Translator's Note.

2 Cf. The Hunting Wasps: passim; Insect Life, by J. H. Fabre, translated by the author of Mademoiselle Mori: chaps. iii. to xii., xiv. to xvii. and xix.; The Life and Love of the Insect, by J. Henri Fabre, translated by Alexander Teixeira de Mattos: chaps. xi. to xii.; and Social Life of the Insect World, by J. H. Fabre, translated by Bernard Miall: chap. xiii.-Translator's Note. 


\section{The Eumenes}

seem to have learnt from some physiologist who allows nothing to escape him; but these skilful slayers have no merit as builders of dwelling-houses. What is their home, in point of fact? An underground passage, with a cell at the end of it; a gallery, an excavation, a shapeless cave. It is miner's work, navvy's work: vigorous sometimes, artistic never. They use the pick for loosening, the crowbar for shifting, the rake for extracting the materials, but never the trowel for laying. Now in the Eumenes we see real masons, who build their houses bit by bit with stone and mortar and run them up in the open, either on firm rock or on the shaky support of a bough. Hunting alternates with architecture; the insect is a Nimrod or a Vitruvius ${ }^{1}$ by turns.

And, first of all, what sites do these builders select for their homes? Should you pass some little garden-wall, facing south, in a sun-scorched corner, look at the stones which are not covered with plaster, look at them one by one, especially the largest; examine the masses of boulders, at no great height from the ground, where the fierce rays have heated them to the temperature of a Turkish

1 Marcus Vitruvius Pollio, the Roman architect and engineer.-Translator's Note. 


\section{The Mason-Wasps}

bath; and perhaps, if you search long enough, you will light upon the structure of Eumenes Amadei. The insect is scarce and lives apart; a meeting is an event upon which we must not count with too great confidence. It is an African species and loves the heat that ripens the carob and the date. It haunts the sunniest spots and selects rocks or firm stones as a foundation for its nest. Sometimes also, but seldom, it copies the Chalicodoma of the Walls ${ }^{1}$ and builds upon an ordinary pebble.

$E$. pomiformis is much more common and is comparatively indifferent to the nature of the foundation on which she constructs her cell. She builds on walls, on isolated stones, on the inner wooden surface of half-closed shutters; or else she adopts an aerial base, the slender twig of a shrub, the withered sprig of a plant of some sort. Any form of support serves her purpose. Nor does she trouble about shelter. Less chilly than her African cousin, she does not shun the unprotected spaces exposed to every wind that blows.

When erected on a horizontal surface, where nothing interferes with it, the struc-

${ }_{1}$ Cf. The Mason-bees, by J. Henri Fabre, translated by Alexander Teixeira de Mattos: chaps. i. to iii. et passim.Translator's Note. 


\section{The Eumenes}

ture of $E$. Amadei is a symmetrical cupola, a spherical skull-cap, having at the top a narrow passage just wide enough for the insect and surmounted by a neatly-funnelled neck. It suggests the round hut of the Eskimo or of the ancient Gael, with its central chimney. An inch, more or less, represents the diameter; three-quarters of an inch the height. When the support is a perpendicular plane, the building still retains the domed shape, but the entrance- and exit-funnel opens at the side, upwards. The floor of this apartment calls for no labour: it is supplied direct by the bare stone.

Having chosen the site, the builder erects a circular fence about an eighth of an inch thick. The materials consist of mortar and small stones. The insect selects its stonequarry in some well-trodden path or on some neighbouring highroad, at the driest, hardest spots. With its mandibles, it scrapes together a small quantity of dust and soaks it with saliva until the whole becomes a regular hydraulic mortar which soon sets and is no longer susceptible to damp. The Mason-bees have shown us a similar exploitation of the beaten paths and of the roadmender's macadam. All these open-air builders, all these erectors of monuments ex- 


\section{The Mason-Wasps}

posed to wind and weather require an exceedingly dry stone-dust; otherwise the material, already moistened with water, would not properly absorb the liquid that is to give it cohesion; and the edifice would soon be wrecked by the rains. They possess the sense of discrimination shown by the plasterer, who rejects plaster injured by the wet. We shall see presently how the insects that build under cover avoid this laborious macadam-scraping and give the preference to fresh earth already reduced to a paste by its own dampness. When common lime answers our purpose, we do not trouble about Roman cement. Now Eumenes Amadei requires a first-class cement, even superior to that of the Chalicodoma of the Walls, for the work, when finished, does not receive the thick outer casing wherewith the Mason-bee protects her cluster of cells. And therefore the cupola-builder, as often as she can, uses the highway as her stone-pit.

With the mortar, bricks are needed. These are bits of gravel of an almost unvarying size - that of a pepper-corn - but of a shape and kind that differ greatly, according to the places worked. Some are sharp-cornered, with facets determined by chance fractures; some are round, polished 


\section{The Eumenes}

by friction under water. Some are of limestone, others of flinty material. The favourite stones, when the neighbourhood of the nest permits, are smooth, semitransparent little lumps of quartz. These are selected with minute care. The insect weighs them, so to say, measures them with the compass of its mandibles and does not accept them until after making sure that they possess the requisite qualities of size and hardness.

A circular fence, we were saying, is begun on the bare rock. Before the mortar sets, which does not take long, the mason, as the work advances, sticks a few stones into the soft mass. She dabs them halfway into the cement, so as to leave them jutting out to a large extent, without penetrating to the inside, where the wall must remain smooth for the sake of the larva's comfort. If necessary, she adds a little plaster, to tone down any inner excrescences. The solidly-embedded stonework alternates with the pure mortarwork, of which each fresh course receives its facing of tiny encrusted pebbles. As the edifice is raised, the builder slopes the construction a little towards the centre and fashions the curve which will give the spherical shape. We 


\section{The Mason-Wasps}

employ arched centerings to support the masonry of a dome while building; the Eumenes, more daring than we, erects her cupola without any scaffolding.

A round opening is contrived at the top; and above this opening rises a funnelled mouth built of pure cement. It might be the graceful neck of some Etruscan vase. When the cell is victualled and the egg laid, the mouth is closed with a cement plug; and in this plug is set a little pebble, one alone, no more: the ritual never varies. This work of rustic architecture has naught to fear from the inclemencies of the weather; it does not yield to the pressure of the fingers; it resists the knife that attempts to remove it without breaking it. Its nippleshape and the bits of gravel wherewith it bristles all over the outside remind one of certain cromlechs of olden time, of certain tumuli whose domes are strewn with $\mathrm{Cy}$ clopean blocks of stone.

Such is the appearance of the edifice when the cell stands alone; but the Wasp nearly always fixes other domes against her first, to the number of five or six or more. This shortens the labour by allowing her to use the same partition for two adjoining rooms. The original elegant symmetry is lost and 


\section{The Eumenes}

the whole now forms a cluster which, at first sight, might be merely a clod of dry mud, sprinkled with little pebbles. But examine the shapeless mass more closely; and we perceive the number of chambers composing the habitation with the funnelled mouths, each quite distinct and each furnished with its gravel stopper set in the cement.

The Chalicodoma of the Walls employs the same building-methods as Eumenes Ama$d e i$ : in the courses of cement, she fixes, on the outside, small stones of minor bulk. Her work begins by being a turret of rustic art, not without a certain prettiness; then, when the cells are placed side by side, the whole construction degenerates into a lump governed apparently by no architectural rule. Moreover, the Mason-bee covers her mass of cells with a thick layer of cement, which conceals the original rockwork edifice. The Eumenes does not resort to this general coating: her building is too strong to need it; she leaves the pebbly facings uncovered, as well as the entrances to the cells. The two sorts of nests, though constructed of similar materials, are therefore easily distinguished.

The Eumenes' cupola is a piece of artist's work; and the artist would be sorry to hide 


\section{The Mason-Wasps}

her masterpiece under whitewash. I crave forgiveness for a suggestion which I advance with all the reserve befitting so delicate a subject. Would it not be possible for the cromlech-builder to take a pride in her handiwork, to look upon it with some affection and to feel gratified by this evidence of her cleverness? Might there not be an insect science of xsthetics? I seem at least to catch a glimpse, in the Eumenes, of a propensity to beautify her product. The nest must be first and foremost a solid habitation, an inviolable stronghold; but, should ornament intervene without jeopardizing the power of resistance, will the worker remain indifferent to it? Who could say?

Let us set forth the facts. The orifice at the top, if left as a mere hole, would suit the purpose quite as well as an elaborate door: the insect would lose nothing in regard to facilities for coming and going and would gain by shortening the labour. Yet we find, on the contrary, the mouth of an amphora, gracefully curved, worthy of a potter's wheel. Choice cement and careful work are needed for the confection of its slender, funnelled shaft. Why this nice fin- 


\section{The Eumenes}

ish, if the builder be wholly absorbed in the solidity of her work?

Here is another detail: among the bits of gravel employed for the outer covering of the cupola, grains of quartz predominate. They are polished and translucent; they glitter slightly and please the eye. Why are these little pebbles preferred to chips of limestone, when both materials exist in equal abundance around the nest?

A yet more remarkable feature: we find pretty often, encrusted on the dome, a few tiny empty Snail-shells, bleached by the sun. The species usually selected by the Eumenes is one of the smaller Helices, Helix strigata, frequent on our parched slopes. I have seen nests where this Helix took the place of pebbles almost entirely. They were like boxes made of shells, the work of a patient hand.

A comparison suggests itself. Certain Australian birds, notably the Bower-birds, build themselves covered walks or arbours with interwoven twigs and decorate the two entrances to the portico by strewing the threshold with anything that they can find in the shape of glittering, polished or brightcoloured objects. Every doorsill is a cab- 


\section{The Mason-Wasps}

inet of curiosities where the collector gathers smooth pebbles, variegated shells, empty Snail-shells, Parrots' feathers, bones that have come to look like sticks of ivory. Even the odds and ends mislaid by man find a home in the bird's museum, where we see pipe-stems, brass buttons, strips of cotton stuff and stone axe-heads.

The collection at either entrance to the bower is large enough to fill half a bushel. As these things are of no use to the bird, its only motive for accumulating them must be an art-lover's hobby. Our common Magpie has similar tastes: any shiny thing that he comes upon he picks up, hides and hoards.

Well, the Eumenes, who shares this passion for bright pebbles and empty Snailshells, is the Bower-bird of the insect world; but she is a more practical collector, knows how to combine the useful and the ornamental and employs her discoveries in the construction of her nest, which is both a fortress and a museum. When she finds bits of translucent quartz, she rejects everything else: the building will be all the prettier for them. When she comes across a little white shell, she hastens to beautify her dome with it; should fortune smile and empty Snail-shells 


\section{The Eumenes}

abound, she encrusts the whole fabric with them, until it becomes the supreme expression of her artistic taste. Is this so or not? Who shall decide?

The nest of Eumenes pomiformis is the size of an average cherry and constructed of pure mortar, without any outer pebblework. Its shape is exactly similar to that which we have just described. When built upon a large enough horizontal base, it is a dome with a central neck, funnelled like the mouth of an urn. But, when the foundation is reduced to a mere point, as on the twig of a shrub, the nest becomes a spherical capsule, always, of course, surmounted by a neck. It is then a miniature specimen of exotic pottery, a big-bellied alcarraza. Its thickness is very slight, less than that of a sheet of paper; it crushes under the least fingerpressure. The outside is not quite even. It displays wrinkles and seams, due to the different courses of mortar, or else knotty projections distributed almost concentrically.

Both Wasps accumulate caterpillars in their coffers, whether domes or jars. Let us give an abstract of the bill of fare. These documents, for all their dryness, possess a value: they will enable whoso 


\section{The Mason-Wasps}

cares to interest himself in the Eumenes to perceive to what extent instinct modifies the diet, according to place and season. The food is plentiful but lacks variety. It consists of tiny caterpillars, by which I mean the grubs of small Butterflies or Moths. This is proclaimed by the structure, for we observe the usual caterpillar organism in the prey selected by either Wasp. The body is composed of twelve segments, not including the head. The first three have true legs, the next two are legless, then come four segments with prolegs, two legless segments and, lastly, a terminal segment with prolegs. It is exactly the same organization which we saw in the Ammophila's Grey Worm.

My old notes give the following description of the caterpillars found in the nest of $E$. Amadei: a pale-green or, less often, yellowish body covered with short white hairs; head wider than the front segment, dead-black and also bristling with hairs. Length: 16 to 18 millimetres; ${ }^{1}$ width: about 3 millimetres. ${ }^{2}$ It is more than a quarter of a century since I jotted down this descriptive sketch; and today, at Sérignan, I

1.63 inch to .7 inch.-Translator's Note.

2.12 inch-Translator's Note. 


\section{The Eumenes}

find in the Eumenes' larder the same sort of game that I saw long ago at Carpentras. Time and distance have not altered the nature of the provisions.

I know one exception and one alone in this fidelity to the ancestral diet. My observations mention a single dish that differs greatly from those which accompany it. This is a caterpillar of the Looper group ${ }^{1}$ with only three pairs of prolegs, placed under the eighth, ninth and twelfth segments. The body tapers slightly at either end, is contracted at the junction of the different rings and is pale green with faint black veinings, visible under the magnifying-glass, and a few sparse black cilia. Length: 15 millimetres; ${ }^{2}$ width: $21 / 2$ millimetres. ${ }^{3}$

$E$. pomiformis also has her preferences. Her game consists of small caterpillars about 7 millimetres long by $\mathrm{I} 1 / 3$. wide. ${ }^{4}$ The body is pale green, pretty sharply contracted at the junction of the segments. The head is narrower than the rest of the body and is spotted with brown. Pale ocel-

1 Also known as the Measuring-worm, the caterpillar of the Geometrid Moth.-Translator's Note.

2.585 inch. - Translator's Note.

3.098 inch.- Translator's Note.

4.27 by .50 inch. - Translator's Note. 


\section{The Mason-Wasps}

lated circles are distributed in two transversal rows over the middle segments and have a black dot in the centre, surmounted by a black cilium. On the third and fourth and also on the penultimate segment, each circle has two black dots and two cilia. This is the rule.

The exception is supplied by two head of game in the whole course of my observations. These two had a pale yellow body, with five longitudinal brick-red stripes and a few very rare cilia. Head and prothorax brown and shiny; length and diameter as above.

The number of pieces served for the meal of each larva interests us more than the quality. In the cells of $E$. Amadei I find sometimes five caterpillars and sometimes ten, which means a difference of a hundred per cent in the quantity of the food, for the pieces are of exactly the same size in both cases. Why this unequal supply, which gives a double portion to one larva and a single portion to another? The consumers have the same appetite: what one nurseling demands a second must demand, unless there be here a menu differing according to the sexes. In the perfect stage, the males are smaller than the females, are hardly 


\section{The Eumenes}

half as much in weight or volume. The amount of victuals, therefore, required to bring them to their final development may be reduced by one-half. In that case, the well-stocked cells belong to females; the others, more meagrely supplied, belong to males.

But the egg is laid when the provisions are stored; and this egg has a determined sex, although the most minute examination is not able to discover the differences which will decide the hatching of a female or a male. We are therefore needs driven to this strange conclusion: the mother knows beforehand the sex of the egg which she is about to lay; ${ }^{1}$ and this knowledge enables her to fill the larder according to the appetite of the future grub. What a strange world, so wholly different from ours! We fall back upon a special sense to explain the Ammophila's hunting; what can we fall back upon to account for this intuition of the future? Can the theory of chances play a part in the hazy problem? If nothing is logically arranged with a foreseen object, how is this clear vision of the invisible acquired?

1 Cf. Bramble-bees and Others, by J. Henri Fabre, translated by Alexander Teixeira de Mattos: chap. iv.-Translator's Note. 


\section{The Mason-Wasps}

The capsules of $E$. pomiformis are literally crammed with game. It is true that the morsels are very small. My notes speak of fourteen green caterpillars in one cell and sixteen in a second. I have no other information about the integral diet of this Wasp, whom I have neglected somewhat, preferring to study her cousin, the builder of rockwork domes. As the two sexes differ in size, though not so greatly as in $E$. Amadei, I am inclined to think that those two well-filled cells belonged to females and that the males' cells must have a less sumptuous table. Not having seen for myself, I am content to set down this mere suspicion.

What I have seen and often seen is the pebbly nest, with the larva inside and the provisions partly consumed. To continue the rearing at home and follow my charges' progress from day to day was a business which I could not resist; besides, so far as I was able to see, it was easily managed. I had had some practice in this foster-father's trade; my association with the Bembex, the Ammophila, the Sphex ${ }^{1}$ and many others had turned me into a passable insect-

1 Cf. The Hunting Wasps: chaps. iv. to viii. and xiii. to xx.-Translator's Note. 


\section{The Eumenes}

breeder. I was no novice in the art of dividing an old pen-box into compartments in which I laid a bed of sand and on this bed the larva, with her provisions, delicately removed from the maternal cell. Success was almost certain at each attempt: I used to watch the larvæ at their meals, I saw my nurselings grow up and spin their cocoons. Relying upon the experience thus gained, I reckoned on success in raising my Eumenes.

The results, however, in no way answered to my expectations. All my endeavours failed; and the larva allowed itself to die a piteous death without touching its provisions.

I ascribed my reverse to this, that and the other cause: perhaps I had injured the frail grub when demolishing the fortress; perhaps a splinter of masonry bruised it when I forced open the hard dome with my knife; perhaps a too-sudden exposure to the sun surprised it when I withdrew it from the darkness of its cell; the open air again might have dried up its moisture. I did the best I could to remedy all these probable reasons of failure. I went to work with every possible caution in breaking open the home; I cast the shadow of my body 


\section{The Mason-Wasps}

over the nest, to save the grub from sunstroke; I at once transferred larva and provisions into a glass tube and placed this tube in a box which I carried in my hand, to minimize the jolting on the journey. Nothing was of avail: the larva, when taken from its dwelling, always pined away and died.

For a long time, I persisted in explaining my failure by the difficulties attending the removal. The cell of Eumenes Amadei is a strong casket which cannot be forced without sustaining a shock; and the demolition of a work of this kind entails such varied accidents that we are always liable to think that the grub has been bruised by the wreckage. As for carrying home the nest intact on its support, with a view to opening it with greater care than is permitted by a rough and ready operation in the fields, that is out of the question: the nest nearly always stands on an immovable rock or on some big stone forming part of a wall. If I failed in my attempts at rearing, it was because the larva had suffered when I was breaking up her house. The reason seemed a good one; and I let it go at that.

In the end, another idea occurred to me and made me doubt whether my rebuffs 


\section{The Eumenes}

were always due to clumsy accidents. The Eumenes' cells are crammed with game: there are ten caterpillars in the cell of $E$. Amadei and fifteen in that of $E$. pomiformis. These caterpillars, stabbed no doubt, but stabbed in a fashion unknown to me, are not entirely motionless. The mandibles seize upon what is presented to them, the body buckles and unbuckles, the hinder half lashes out briskly when stirred with the point of a needle. At what spot is the egg laid amid that swarming mass, where thirty mandibles can make a hole in it, where a hundred and twenty pair of legs can tear it? When the victuals consist of a single head of game, these perils do not exist; and the egg is laid on the victim not at hazard, but upon a judiciously chosen spot. Thus, for instance, the Hairy Ammophila fixes hers, by one end, across the Grey Worm, on the side of the first prolegged segment. The egg hangs over the caterpillar's back, away from the legs, whose proximity might be dangerous. The worm, moreover, stung in the greater number of its nerve-centres, lies on its side, motionless and incapable of bodily contortions or sudden jerks of its hinder segments. If the mandibles try to snap, if the legs give 


\section{The Mason-Wasps}

a kick or two, they find nothing in front of them: the Ammophila's egg is in the opposite direction. The little grub is thus able, as soon as it hatches, to dig into the giant's belly in full security.

How different are the conditions in the Eumenes' cell! The caterpillars are imperfectly paralysed, perhaps because they have received but a single stab; they toss about when touched with a pin; they are bound to wriggle when bitten by the larva. If the egg is laid on one of them, this first morsel will, I admit, be consumed without danger, on condition that the point of attack be wisely chosen; but there remain others which are not deprived of every means of defence. Let a movement take place in the mass; and the egg, shifted from the upper layer, will tumble into a trap of legs and mandibles. The least thing is enough to jeopardize its existence; and this least thing has every chance of being brought about in the disordered heap of caterpillars. The egg, a tiny cylinder, transparent as crystal, is extremely delicate: a touch withers it; the least pressure crushes it.

No, its place is not in the mass of provisions, for the caterpillars, I repeat, are 


\section{The Eumenes}

not sufficiently harmless. Their paralysis is incomplete, as is proved by their contortions when I irritate them and evidenced moreover by a very important fact. I have sometimes taken from the cell of Eumenes Amadei a few head of game half-transformed into chrysalids. It is evident that the transformation was effected in the cell itself and therefore after the operation which the Wasp had performed upon them. Whereof does this operation consist? I cannot say precisely, never having seen the huntress at work. The sting most certainly has played its part; but where? And how often? This is what we do not know. What we can declare is that the torpor is not very profound, inasmuch as the patient sometimes retains enough vitality to shed its skin and become a chrysalis. Everything thus tends to make us ask by what stratagem the egg is shielded from danger.

This stratagem I longed to discover; I would not be put off by the scarcity of nests, by the irksomeness of the search, by the risk of sunstroke, by the time taken up in the vain breaking open of unsuitable cells; I meant to see and I saw. Here is my method: with the point of a knife and a pair of nippers, I make a side opening, a window, 


\section{The Mason-Wasps}

beneath the dome of $E$. Amadei and $E$. pomiformis. I work with the greatest care, so as not to injure the recluse. I used to attack the cupola from the top; I now attack it from the side. I stop when the breach is large enough to allow me to see the state of things within.

What is this state of things? I pause to give the reader time to reflect and to think out for himself a means of safety that will protect the egg and afterwards the grub in the perilous conditions which I have set forth. Seek, think and contrive, such of you as have inventive minds. Have you guessed it? Do you give it up? I may as well tell you.

The egg is not laid upon the provisions; it hangs from the top of the cupola by a thread which vies with that of a Spider's web for slenderness. The dainty cylinder quivers and swings at the least breath; it reminds me of the famous pendulum hung from the dome of the Panthéon to prove the rotation of the earth. The victuals are heaped up underneath.

Second act of this wondrous spectacle. In order to witness it, we must open a window in cell after cell until fortune deigns to smile upon us. The larva is hatched and 


\section{The Eumenes}

already fairly large. Like the egg, it hangs perpendicularly, by its rear-end, from the ceiling; but the suspension-cord has gained considerably in length and consists of the original thread eked out by a sort of ribbon. The grub is at dinner: head downwards, it is digging into the limp belly of one of the caterpillars. I touch up the game that is still intact with a straw. The caterpillars grow restless. The grub forthwith retires from the fray. And how? Marvel is added to marvel: what I took for a flat cord, for a ribbon, at the lower end of the suspension-thread, is a sheath, a scabbard, a sort of ascending gallery wherein the grub crawls backwards and makes its way up. The cast shell of the egg, retaining its cylindrical form and perhaps lengthened by a special operation on the part of the newborn larva, forms this safety-channel. At the least sign of danger in the heap of caterpillars, the larva retreats into its sheath and climbs back to the ceiling, where the swarming rabble cannot reach it. When peace is restored, it slides down its case and returns to table, with its head over the viands and its rear upturned and ready to withdraw in case of need.

Third and last act. Strength and vigour 


\section{The Mason-Wasps}

have come; the larva is sturdy enough not to dread the movements of the caterpillars' bodies. Besides, the caterpillars, mortified by fasting and weakened by a prolonged torpor, become more and more incapable of defence. The perils of the tender babe are succeeded by the security of the lusty stripling; and the grub, henceforth scorning its sheathed lift, lets itself drop upon the game that remains. And thus the banquet ends in normal fashion.

That is what I saw in the nests of both species of Eumenes, that is what I showed to friends who were even more surprised than I by these ingenious tactics. The egg hanging from the ceiling, at a distance from the provisions, has naught to fear from the caterpillars, which flounder about below. The newly-hatched worm, whose suspension-cord is lengthened by the sheath of the egg, reaches the game and takes a first cautious bite at it. If there be danger, it climbs back to the ceiling by retreating inside the scabbard. This explains the failure of my earlier attempts. Not knowing of the safety-thread, so slender and so easily broken, I gathered at one time the egg, at another the young larva, after my inroads at the top had caused them to fall into the 


\section{The Eumenes}

midst of the live provisions. Neither of them was able to thrive when brought into direct contact with the dangerous game.

If any one of my readers, to whom I appealed just now, has thought out something better than the Eumenes' invention, I beg that he will let me know, for there is a curious parallel to be drawn between the inspirations of reason and those of instinct. 


\section{CHAPTER II}

\section{THE ODYNERI}

THE Eumenes' suspension-cord and as1 cending-sheath are rendered necessary by the large number and the incomplete paralysis of the caterpillars provided for the larva; the object of the ingenious system is to avert danger. This, at least, is how I regard the concatenation of causes and effects. But I yield to no one in my distrust of whys and wherefores; I know how slippery our footing becomes when we venture on interpretations; and, before declaring the reasons of any fact observed, I seek for a batch of proofs. If the singular installation of the Eumenes' egg is really due to the reasons suggested, then, wherever we find similar conditions of danger, namely, a multiplicity of dishes combined with incomplete torpor, we must also find a similar method of protection, or some other method having an equivalent effect. The repetition of the act will bear witness to the correctness of the interpretation; and, if it is not reproduced elsewhere, with such varia- 


\section{The Odyneri}

tions as may be required, the case of the Eumenes will remain a very curious instance, without acquiring the far-reaching significance which I suspect it of bearing. Let us generalize, the better to establish the facts.

Now not far removed from the Eumenes are the Odyneri, the Solitary Wasps observed by Réaumur. ${ }^{1}$ They have the same costumes, the same wings folded lengthwise, the same predatory instincts and, above all, as the supreme condition, the same accumulations of prey retaining sufficient power of movement to be dangerous. If my arguments are well-founded, if I am right in my conjectures, the egg of the Odynerus should be slung from the ceiling of the cell like the egg of the Eumenes. My conviction, based upon logic, is so positive that I already seem to see this egg, recently laid, quivering at the end of the life-line.

Ah, I confess that it needed a robust faith to cherish the audacious hope of discovering anything further when the masters had seen nothing! I read and reread Réaumur's essay on the Solitary Wasp.

1 René Antoine Ferchault de Réaumur (1683-1757), inventor of the Réaumur thermometer and author of Mémoires pour servir à l'histoire naturelle des insectes.Translator's Note. 


\section{The Mason-Wasps}

The Insect's Herodotus gives us a host of particulars, but says nothing, absolutely nothing, about the hanging egg. I consult Léon Dufour, ${ }^{1}$ who treats subjects of this kind with his usual raciness: he has seen the egg; he describes it; but of the suspension-thread not a word. I consult Lepeletier, ${ }^{2}$ Audouin, ${ }^{3}$ Blanchard: ${ }^{4}$ they are absolutely silent on the means of protection which I expect to find. Is it possible that a detail of such great importance can have escaped all these observers? Am I the dupe of my imagination? Is the protective system, though proved to my mind by close logical reasoning, merely one of $\mathrm{my}$

1 Jean Marie Léon Dufour (1780-1865), an army surgeon who served with distinction in several campaigns and afterwards practised as a doctor in the Landes, where he attained great eminence as a naturalist. Fabre often refers to him as the Wizard of the Landes. Cf. The Life of the Spider, by J. Henri Fabre, translated by Alexander Teixeira de Mattos: chap. $\mathrm{i}$; and The Life of the Fly, by J. Henri Fabre, translated by Alexander Teixeira de Mattos: chap. i.-Translator's Note.

2 Amédée Comte Lepeletier de Saint-Fargeau (1769circa 1850 ), author of an Histoire naturelle des insectes (1836-1846) and of the volume on insects in the Encyclopédie méthodique. He was a younger brother of Louis Michel and Félix Lepeletier de Saint-Fargeau, the members of the Convention.-Translator's Note.

3 Jean Victor Audouin (1797-1841), founder of the $A n$ nales des sciences naturelles and author of a number of works on insects injurious to agriculture.-Translator's Note.

${ }^{4}$ Emile Blanchard (b. 1820 ), author of various works on insects, Spiders, etc. - Translator's Note. 


\section{The Odyneri}

dreams? Either the Eumenes have lied to me or my hopes are justified. As a disciple rebelling against his masters, a disciple strong in arguments which I believed invincible, I set to work investigating, convinced that I should succeed. And I did succeed; I found what I was looking for; I found something better still. Let me set things down in detail.

There are various Odyneri established in my neighbourhood. I know one who takes possession of the abandoned nests of $E u$ menes Amadei. This nest, a structure of unusual solidity, is not a ruin when its owner moves away; it loses only its neck. The cupola, preserved untouched, is a fortified retreat of too convenient a nature to remain vacant. Some Spider adopts the cavern, after lining it with silk; Osmiæ ${ }^{1}$ take refuge in it in rainy weather, or else make it their dormitory, wherein to spend the night; an Odynerus divides it, by means of clay partitions, into three or four chambers, which become the cradles of as many larvæ. A second species uses the deserted nests of the Pelopæus; ${ }^{2}$ a third, removing the pith from

1 Cf. Bramble-bees and Others: chaps. i. to vii.-Translator's Note.

2 Cf. Chapter III. of the present volume-Translator's Note. 


\section{The Mason-Wasps}

a dry bramble-stem, obtains, for the use of her family, a long sheath, which she subdivides into stories; a fourth bores a gallery in the dead wood of some fig-tree; a fifth digs herself a shaft in the soil of a footpath and surmounts it with a cylindrical, vertical kerb. All these industries are worth studying, but I should have preferred to discover that which Réaumur and Dufour have rendered famous.

On a steep bank of red clay, I at length recognize, in no great profusion, the signs of a village of Odyneri. Here are the characteristic chimneys mentioned by the two historians, that is to say, the curved tubes, with their guilloche-work, that hang at the entrance to the dwelling. The bank is exposed to the heat of the noonday sun. A little tumbledown wall surmounts it; behind is a dense screen of pines. The whole forms a warm refuge, such as the Wasp requires for setting up house. Moreover, we are now in the second fortnight of the month of May, which is just the workingseason, according to the masters. The outside architecture, the site and the period all agree with what Réaumur and Léon Dufour have told us. Have I really chanced upon one or other of their Odyneri? This re- 


\section{The Odyneri}

mains to be seen and without delay. Not one of the ingenious constructors of guilloche porticoes shows herself, not one arrives; I must wait. I take up my position close by, to watch the homing insects.

Ah, how long the hours seem, spent motionless, under a burning sun, at the foot of a declivity which sends the heat of an oven beating down upon you! Bull, my inseparable companion, has retired some distance into the shade, under a clump of evergreen oaks. He has found a layer of sand whose depths still retain some traces of the last shower. He digs himself a bed; and in the cool furrow the sybarite stretches himself flat upon his belly. Lolling his tongue and thrashing the boughs with his tail, he keeps his soft, deep gaze fixed upon me :

"What are you doing over there, you booby, baking in the heat? Come here, under the foliage; see how comfortable I am!"

That is what I seem to read in my companion's eyes.

"Oh, my Dog, my friend," I should answer, if you could only understand, "man is tormented by a desire for knowledge, whereas your torments are confined to a de- 


\section{The Mason-Wasps}

sire for bones and, from time to time, a desire for your sweetheart! This, notwithstanding our devoted friendship, creates a certain difference between us, even though people nowadays say that we are more or less related, almost cousins. I feel the need to know things and am content to bake in the heat; you feel no such need and retire into the cool shade."

Yes, the hours drag when you lie waiting for an insect that does not come. In the pinewood hard by, a couple of Hoopoes are chasing each other with the amorous provocations of spring:

"Oopoopoo!" cries the cock, in a muffled tone. "Oopoopoo!"

Latin antiquity called the Hoopoe Upupa; Greek antiquity named it 'Елоч. But Pliny turned the $\vec{\epsilon}$ into $o u$ and must have pronounced the word Oupoupa, as the cry imitated by the name teaches me to do. Rarely have I received a lesson in Latin pronunciation better authenticated than yours, ${ }^{1}$ you beautiful bird, who provide a diversion for my long hours of weariness. Faithful to your idiom, you say "Oopoopoo!" as you said in the days of

1 The French, it may hardly be necessary to explain, pronounce Latin precisely as though it were French.Translator's Note. 


\section{The Odyneri}

Aristotle and Pliny, as you said when your note sounded for the first time. But our own idioms, our primitive idioms, what has become of them? The scholar cannot even recover their traces. Man alters; animals do not change.

At last, here we are at last! See, the Odynerus arrives, with a flight as silent as the Eumenes'. She disappears into the curved cylinder of the vestibule, bringing home a grub beneath her abdomen. I place a small glass test-tube at the entrance to the nest. When the insect emerges, it will be caught. Done! The Wasp is caught and at once decanted into the asphyxiating-flask, with its strips of paper steeped in bisulphide of carbon. And now, my Dog, still lolling your tongue and frisking your tail, we can be off; the day has not been wasted. We will come back tomorrow.

Upon investigation, my Odynerus does not correspond with what I expected to see. This is not the species of which Réaumur speaks (O. spinipes); nor is it the species studied by Dufour (O. Reaumurii); it is another. (O. reniformis, LATR.), a different one, though addicted to the same arts. Already the naturalist of the Landes had 


\section{The Mason-Wasps}

allowed himself to be deceived by that similarity in architecture, provisions and habits; he thought that he was observing Réaumur's Solitary Wasp, whereas in reality his tube-builder presented specific differences.

We know the worker; it remains for us to become acquainted with her work. The entrance to the nest opens in the perpendicular wall of the bank. It is a round hole, on the edge of which is built a curved tube, with the orifice turned downwards. Made with the materials cleared from the burrow under construction, this tubular vestibule is composed of grains of earth, not arranged in continuous courses, but leaving small vacant intervals. It is a species of openwork, a lacework of clay. Its length is about an inch and its internal diameter a fifth of an inch. This portico is continued by the gallery, of the same diameter, which slants into the soil to a depth of nearly six inches. Here this main gallery branches into short corridors, each giving access to a cell which is independent of its neighbours. Each larva has its chamber, which can be reached by a special passage. I have counted as many as ten of them; and there may be more. These chambers have no- 


\section{The Odyneri}

thing remarkable about them, either in construction or in capacity; they are just culsde-sac ending the corridors that give access to them. Some are horizontal, some more or less sloping; there is no fixed rule. When a cell contains what it is meant to contain, the egg and the provisions, the Odynerus closes the entrance with a little earthen lid; she then digs another near it, on one side of the principal gallery. Lastly, the common road to the cells is blocked with earth; the tube at the entrance is demolished, to furnish material for the work done inside the nest; and every vestige of the habitation disappears.

The surface of the bank is of clay baked in the sun; it is almost brick. I break into it with difficulty, making use of a small pocket-trowel. Underneath, it is much less hard.

How does the frail miner manage to sink a gallery in this brick? She employs, I cannot doubt, the method described by Réaumur. I will therefore reproduce a passage from the master's writings, to give my younger readers a glimpse into the habits of the Odyneri, habits which my very small colony did not enable me to observe in all their details: 


\section{The Mason-Wasps}

"It is at the end of May that these Wasps set to work; and one can see them busily labouring during the whole of June. Though their actual object is only to dig in the sand a hole a few inches deep and not much wider than their bodies, one might suppose that they had another end in view; for, to make this hole, they build on the outside a hollow tube, which has as its base the circumference of the entrance to the hole and which, after following a direction perpendicular to the surface containing that aperture, turns downwards. This tube becomes longer in proportion as the hole becomes deeper; it is built of the sand drawn from the hole; it is fashioned in coarse filigree, or a sort of guilloche. It is made of big, granular, winding fillets, which do not touch at all points. The gaps left in between make it look as if it were artistically constructed, whereas it is only a sort of scaffolding by means of which the mother's tactics are rendered swifter and surer.

"'Though I knew these insects' two teeth to be capital instruments, capable of breaking into very hard substances, the task which they had to perform appeared to me rather severe for them. The sand on which they had to act was scarcely less hard than ordi- 


\section{The Odyneri}

nary stone; at least, one's finger-nails made but a poor impression upon its outer layer, which the sun's rays had dried more thoroughly than the rest. But, when I succeeded in observing these workers at the moment when they were beginning to bore a hole, they taught me that they did not need to subject their teeth to so harsh an ordeal.

"I saw that the Wasp begins by softening the sand which she proposes to remove. Her mouth discharges upon it a drop or two of water, which is promptly swallowed by the sand, turning it instantly into a soft paste which her teeth scrape and remove without difficulty. Two of her legs, the foremost pair, immediately proceed to gather it into a little pellet, about the size of a currant-seed. It is with this pellet, the first one removed, that the Wasp lays the foundations of the tube which we have described. She carries her pellet of mortar to the edge of the hole which she has just made by removing it; her teeth and feet turn it about, flatten it and make it stand up higher than it did before. This done, the Wasp again sets about removing sand and loads herself with another pellet of mortar. Soon she contrives to have extracted enough 


\section{The Mason-Wasps}

sand to make the entrance of the hole perceptible and to have laid the foundation of the tube.

"But the work can proceed quickly only so long as the Wasp is able to moisten the sand. She is obliged to take trouble to renew her store of water. I do not know whether she simply went to take in water at some stream, or whether she drew, from some plant or fruit, a more sticky fluid; what I do know is that she returned without delay and set to work with renewed zeal. I observed one Wasp who managed, in about an hour, to sink a hole the length of her body and who raised a chimney as tall as the hole was deep. At the end of a few hours the tube stood two inches high and she was still deepening the hole that lay underneath.

"It did not appear to me that she had any rule respecting the depth which she gives it. I have found some whose hole ran more than four inches from the orifice; others whose hole measured only two or three inches. Again, over one hole you will find a tube twice or three times as long as that over another. Not all the mortar removed from the hole is invariably employed to prolong it. In cases where the 


\section{The Odyneri}

Wasp has given the tube a length which she considers sufficient, you see her simply arrive at the opening to the tube, put her head beyond its edge and forthwith drop her pellet, which falls to the ground. In this way I have often observed a quantity of rubbish at the foot of certain holes.

"The object for which the hole is pierced in a solid mass of mortar or sand cannot appear in doubt: it is plainly intended to receive an egg, together with a store of foodstuffs. But we do not so easily see to what end the mother has built the mortar shaft. By continuing to follow her labours, we shall discover that it means to her what a stack of well-laid stones means to the masons building a wall. Not the whole of the tunnel which she has excavated is intended as a lodging for the larva which will be born inside; a portion will be quite enough. Yet it was necessary that the hole should be dug to a certain depth, in order that the larva may not find itself exposed to too great a heat when the sun's rays fall on the outer layer of sand. It will occupy only the end of the tunnel. The mother knows what space she must leave vacant and this space she retains; but she fills up all the remainder and replaces in the upper 


\section{The Mason-Wasps}

portion of the hole as much of the sand removed from it as is necessary to stop it up. It is to have this mortar within reach that she has built that shaft. Once the egg is laid and the store of victuals placed within its reach, we see the mother come and gnaw the end of the shaft, after first moistening it, carry the pellet inside and next return for more, in the same manner, until the hole is blocked right up to the opening."

Réaumur goes on to speak of the victuals heaped up in the cells, the "green grubs," as he calls them, heedless of the ugly alliteration. Not having seen the same things, because my Odynerus is of a different species, I will continue my story. I counted the head of game in three cells only: the colony was a small one; I had to deal tenderly with it if I would follow its history to the end. In one of the cells, before the provisions were broached, I counted twentyfour pieces; in each of the two others, which were likewise intact, I counted twenty-two. Réaumur found only eight to twelve pieces in the larder of his Odynerus; and Dufour,

1 Réaumur's actual words are "vers verts;" and Fabre rightly complains of "the hideous assonance."-Translator's Note. 


\section{The Odyneri}

in the store-room of his, discovered a batch of ten to twelve. Mine requires twice as many, a couple of dozen, which may be due to the smaller size of the game. No predatory Wasp of my acquaintance, apart from the Bembeces, ${ }^{1}$ who obtain their supplies from day to day, approaches this prodigality in numbers. Two dozen grubworms to make a meal for only one! How far removed are we from the single caterpillar of the Hairy Ammophila! And what delicate precautions must be taken for the safety of the egg in the midst of such a crowd! A scrupulous vigilance is necessary here, if we would obtain a true conception of the dangers to which the Odynerus' egg is exposed and of the means that save it from danger.

And, in the first place, what variety of game is this? It consists of worms as thick as a knitting-needle and varying slightly in length. The biggest measure a centimetre. $^{2}$ The head is small, of an intense, glossy black. The segments, unlike those of the caterpillars, have no legs, either true or false, but all, without exception, are furnished with ambulatory organs in the

1 For the Bembex cf. The Hunting Wasps: chaps. xiv. to xvi.-Translator's Note.

2.39 inch. - Translator's Note. 


\section{The Mason-Wasps}

shape of a pair of small fleshy nipples. These worms, though of the same species, to judge by their general characteristics, differ in colouring. They are a pale, yellowish green, with two wide longitudinal stripes of pale pink in some and of a more or less deep green in others. Between these two stripes, on the back, runs a streak of pale yellow. The whole body is sprinkled with little black tubercles, each bearing a hair on its crest. The absence of legs proves that they are not caterpillars, not the larvæ of Butterflies or Moths. According to Audouin's experiments, Réaumur's "green grubs" are the larvæ of a Weevil, Phytonomus variabilis, an inhabitant of the lucerne-fields. Can my worms, pink or green, also belong to some little Weevil? It is quite possible.

Réaumur described the grubs composing the victuals of his Odynerus as alive; he tried to rear some, hoping to see a Fly or a Beetle appear from them. Léon Dufour, on his side, called them live caterpillars. The mobility of the game provided escaped neither of the two observers; they had before their eyes grubs that moved about and gave full signs of life.

What they saw I also see. My little 44 


\section{The Odyneri}

larva frisk and fidget; curled at first in the shape of a ring, they uncurl themselves and curl again, if I do no more than slowly turn the small glass tube in which I have imprisoned them. When touched with the point of a needle, they struggle abruptly. Some succeed in shifting their position. While engaged in rearing the Odynerus' egg, I opened the cell lengthwise, so as to reduce it to a semicylinder; in the little trench thus made, which was kept horizontal, I placed a few head of game. Next day usually I found that one of them had fallen out, a proof of movement, of a change of position, even when nothing was disturbing its repose.

These larvæ, I am firmly convinced, have been wounded by the Odynerus' sting, for she would not carry a rapier merely for show. Possessing a weapon, she employs it. However, the wound is so slight that Réaumur and Léon Dufour did not suspect its existence. To their mind the prey was alive; to mine it is very nearly alive. In these conditions we can see to what perils the Odynerus' egg would be exposed but for exquisitely prudent precautions. There they are, those restless grubs, to the number of two dozen in one cell, side by side with 


\section{The Mason-Wasps}

the egg, which a mere nothing is enough to endanger. By what means will this very delicate germ escape the perils of the crowd?

As I foresaw by my process of reasoning, the egg is slung from the ceiling of the cell. A very short thread fastens it to the top wall and lets it hang free in space. The first time that I saw this egg, quivering at the end of its thread at the least jerk and confirming by its oscillations the correctness of my theoretical views, I experienced one of those moments of inward joy which atone for much vexation and weariness. I was to have many more such moments, as will be seen. If we pursue our investigations in the insect world with loving patience and a practised eye, we always find some marvel in store for us. The egg, I was saying, swings from the ceiling, held by a very short and extremely fine thread. The cell is sometimes horizontal, sometimes slanting. In the first case, the egg hangs perpendicularly to the axis of the cell and its lower end approaches to within a twelfth of an inch of the opposite wall; in the second case, the vertical direction of the egg forms a more or less acute angle with that axis.

I wished to follow the progress of this 46 


\section{The Odyneri}

hanging egg at my leisure, with the greater convenience of observation which is possible at home. With the egg of Eumenes Amadei this was all but impracticable, because of the cell, which could not be moved together with the block that most often serves as its foundation. A house of this kind demands observation on the spot. The Odynerus' dwelling does not present the same drawback. When a cell is laid bare and found to be in the condition which I desire, I dig round it with the point of a knife until I detach a cylinder of earth containing the cell, which is reduced to an open trough, so as to conceal nothing of what is to happen inside. The victuals are extracted piecemeal, with every care, and decanted separately into a glass tube. I shall thus avoid the accidents that might be occasioned by the swarming heap of grubs during the inevitable shaking of the journey. The egg alone remains, swinging in the empty enclosure. A large tube receives the cylinder of earth, which is wedged in position with pads of cotton-wool. I place my booty in a tin box and carry it in my hand in such a position that the egg hangs vertically without striking against the walls of the cell. 


\section{The Mason-Wasps}

Never have I effected a removal which called for such nice precautions. An accidental movement might easily break the suspension-thread, which is so delicate that it needs the magnifying-glass to distinguish it; excessive oscillation might bruise the egg against the walls of the cell: I had to beware of turning it into a sort of bell-clapper dashing against its bronze prison. I walked, therefore, with the stiffness of an automaton, all of one piece, with steps methodically calculated. What a misfortune should some acquaintance appear and make me stop a moment, for a chat or a shake of the hand: the least distraction on my part would perhaps ruin my schemes! Still more embarrassing would it be should Bull, who cannot endure a black look, find himself muzzle to muzzle with a rival and try to get quits with him by flying at his throat. I should have to put an end to the fray, to avoid the scandal of a wellbrought-up Dog showing intolerance of the village cur. The squabble would end in the breakdown of all my experimental scaffolding. And to think that the eager preoccupations of a person not entirely devoid of sense may sometimes be dependent on a Dog-fight! 


\section{The Odyneri}

Lord be praised, the road is deserted! The journey is accomplished without hindrance; the thread, my great anxiety, does not break; the egg is not bruised; everything is in order. The little clod of earth is put in a place of safety, with the cell in a horizontal position. I distribute near the egg two or three of the grubs which I have collected; the complete allowance of provisions would cause trouble, now that the cell possesses only half its enclosing wall and is reduced to a semicylinder. Two days later, I find the egg hatched. The young larva, yellow in colour, is hanging by its hinder end, head downwards. It is busy with its first grub, whose skin is already growing limp. The suspension-cord consists of the short thread that supported the egg, with the addition of the slough, now reduced to a sort of crumpled ribbon. In order to remain sheathed in the end of this hollow ribbon, the hinder end of the newborn larva is at first slightly constricted and then swells into a button. If I disturb it while at rest, or if the victuals move, the larva withdraws, shrinking back upon itself, but without retreating into the ascending-sheath, as does the Eumenes' larva. The tethering-cord does not serve as a scab- 


\section{The Mason-Wasps}

bard, as a refuge into which the larva can retire; it is rather an anchor-chain, which gives it a purchase on the ceiling and enables it to protect itself by shrinking to a safe distance from the heap of victuals. When things are quiet, the larva lengthens out and returns to its grub. Thus do matters happen at the start, according to my observations, of which some were made at home, in my rearing-jars, and others on the spot, when I unearthed cells containing a larva young enough for my purpose.

The first grub is devoured in twenty-four hours. The larva thereupon, so it seemed, goes through a moult. For at least some time it remains inactive and contracted; then it releases itself from the cord. It is now free, in contact with the heap of grubs and henceforth unable to step out of the way. The life-line has not lasted long; it protected the egg and safeguarded its hatching; but the larva is still very weak and the peril has not diminished. This means that we shall discover other means of protection.

By a very strange exception, whereof so far I know no other instance, the egg is laid before the provisions are stored. I have seen cells which as yet contained absolutely nothing in the way of victuals and which 


\section{The Odyneri}

nevertheless had the egg swinging from the ceiling. I have seen others, also furnished with the egg and so far containing only two or three head of game, a first instalment of the abundant dish of twenty-four. This early egg-laying, so utterly unlike what happens in the case of the other predatory Wasps, has its underlying motive, as we shall see; it has its logic at which we cannot fail to marvel.

The egg, laid in the empty cell, is not fixed at random on the first spot that offers upon the enclosing wall, which is vacant at all sides; it is hung near the far end, opposite the entrance. Réaumur had already noted this position of the budding larva, but without insisting on a detail whose importance he did not suspect:

"The grub," he says, "is born at the bottom of the hole, that is, at the back of the cell."

He does not speak of the egg, which he does not appear to have seen. This position of the grub was so well known to him that, wishing to attempt the rearing of a grub in a glass cell made with his own hands, he placed the larva at the bottom and the victuals on top of it. 


\section{The Mason-Wasps}

Why do I linger over a petty detail which the famous historian of the Odyneri tells in half-a-dozen words? A petty detail? It is nothing of the kind; on the contrary, it is a circumstance of paramount importance. And this is why : the egg is laid at the back, necessitating an empty cell which will be victualled after the egg is laid. The provisions are now stored, piece by piece, layer upon layer, in front of the egg; the cell is crammed with game right up to the entrance, which in the end is sealed.

Of all these pieces, the obtaining of which may take several days, which are the earliest in point of date? Those nearest the egg. Which are the latest? Those by the entrance. Now it is obvious - besides, it may be proved, if necessary, by direct observation - it is obvious, I say, that the heaped worms lose strength from day to day. The effects of a prolonged fast would be enough to produce this result, to say nothing of the disorders due to a wound which becomes worse as time goes on. The larva born at the back of the cell has therefore beside it, in its first youth, the less dangerous provisions, the oldest in date and consequently the feeblest. As it works its way through the heap, it finds more recent 


\section{The Odyneri}

game, which is also more vigorous; but this is attacked without danger, because the larva's own strength has come.

This progress from the more to the less nearly mortified victims presumes that the grubs do not disturb the order in which they have been stacked. That in fact is what happens. Former historians of the Odyneri have all remarked that the grubs provided for the larva are curled in the shape of a ring:

"The cell," says Réaumur, "was occupied by green rings, to the number of eight or twelve. Each of these rings consisted of a vermiform larva, alive, curled up and with its back fitting exactly against the wall of the hole. These grubs, laid in this way one on top of the other and even pressed together, had no liberty of movement."

I, in my turn, remark similar facts in my two dozen grub-worms. They are curled in a ring; they are stacked one upon another, but with a certain confusion in the ranks; their backs touch the wall. I will not attribute this circular curve to the effect of the sting which was very probably administered, for I have never observed it in 


\section{The Mason-Wasps}

the caterpillars stabbed by the Ammophilæ; I believe rather that the position is natural to the grub during inaction, even as it is natural for the Iuli ${ }^{1}$ to coil themselves into a spiral. In this living bracelet there is a tendency to return to the rectilinear conformation; it is a bent bow fighting against the obstacle that surrounds it. By the very fact, therefore, of being curled up, each grub keeps more or less steady by pressing its back a little against the wall; and it retains its place even when the cell approaches the vertical.

Moreover, the shape of the cell has been calculated with a view to this manner of storing. In the part next the entrance, the part which one might call the store-room, the cell is cylindrical and narrow, so as to afford the living rings as little space as possible; they are thus kept in position and are unable to slip. It is here that the grubs are stacked, squeezed one against the other. At the other end, near the back, the cell expands into an ovoid to give the larva elbow-room. The differences between the two diameters is very perceptible. At the entrance I find only four millimetres: ${ }^{2}$ at

1 The Iulus belongs to the Myriapod family, which includes the Centipedes, etc.-Translator's Note.

2.156 inch.-Translator's Note. 


\section{The Odyneri}

the back I find six. ${ }^{1}$ Thanks to this inequality of width, the cell comprises two apartments: the provision-store in front and the dining-room behind. The Eumenes' spacious cupola does not permit of this arrangement; there the game is heaped up in disorder, the oldest in date promiscuously with the most recent; and each piece is merely bent, not rolled. The ascendingsheath provides a remedy for the disadvantages of this confusion.

Note also that the packing of the victuals is not the same from one end of the Odynerus' skewerful to the other. In the cells whose provisions have not yet or have only recently been broached, I observe this detail: near the egg or the newly-hatched larva, in the part which I have just described as the dining-room, the space is not fully occupied; there are just a few grubs here, three or four, somewhat isolated from the bulk and leaving enough room to ensure the safety of either the egg or the young larva. This is the food supplied for the early meals. If there be danger in the first mouthfuls, which are the most risky of all, the life-line provides a means of withdrawal. More towards the front, the game

1.234 inch,-Translator's Note. 


\section{The Mason-Wasps}

is piled in close-packed layers, the stack of worms is continuous.

Will the larva, now that it possesses a modicum of strength, force itself imprudently into this heap? Far from it. The victuals are consumed in due order, from the bottommost to the topmost. The larva drags towards it, to a little distance, into the dining-room, the first ring that offers, devours it without danger of being inconvenienced by the others and thus, layer by layer, consumes the batch of two dozen, always in complete security.

Let us retrace our steps and end with a brief summary. The large number of grubs provided for a single cell and their very incomplete paralysis jeopardize the security of the Wasp's egg and of her newborn larva. How is the danger to be averted? This is the problem; and it has several solutions. The Eumenes, with her sheath, which enables the larva to climb back to the ceiling, gives us one; the Odynerus, in her turn, gives us hers, a solution no less ingenious and much more complicated.

The egg and also the newly-hatched larva have to be saved from the danger of contact with the game. A suspension-thread solves 


\section{The Odyneri}

the difficulty. Up to this point, that is the method adopted by the Eumenes; but soon the young larva, having eaten its first grub, drops off the thread that gave it a support whereby to shrink out 'of harm's way. A sequence of conditions now begins, all directed towards its welfare.

Prudence demands that the very young larva shall first attack the most inoffensive of the grubs, that is those most nearly deadened by abstinence, in short, the grubs first placed in the cell; it demands, moreover, that the consumption of these grubs shall proceed from the oldest specimens to the most recent, so that the larva may have fresh game to the end. With this object, a curious exception is made to the general rule: the egg is laid before the victualling is commenced. It is laid at the back of the cell; in this way, the stacked provisions will present themselves to the larva in due order of date.

That is not enough: it is important that the grubs shall be unable, in moving, to alter their respective positions. This circumstance is provided for: the store-room is a narrow cylinder in which change of place is difficult.

Even that is not sufficient: the larva must 


\section{The Mason-Wasps}

have room enough to move about at ease. The condition is fulfilled: at the back, the cell forms a comparatively spacious diningroom:

Is that all? Not yet. The diningroom must not be encumbered like the rest of the cell. The matter has been seen to: the first course consists of a small number of specimens.

Have we done? By no means. It is not of any use to have a narrow cylinder for the larder: if the grubs straighten out, they will slip lengthwise and disturb the nurseling in the back-room. This has been remedied: the game selected is a larva which deliberately rolls itself into a bracelet and maintains its position by its own tendency to unbend.

It is by the ingenious removal of this series of difficulties that the Odynerus succeeds in leaving a family. We have seen enough of her exquisite foresight to amaze us. What would it be were nothing to remain concealed from our dull eyes!

Can the insect have acquired its skill gradually, from generation to generation, by a long series of casual experiments, of blind gropings? Can such order be born of chaos; such foresight of hazard; such 


\section{The Odyneri}

wisdom of stupidity? Is the world subject to the fatalities of evolution, from the first albuminous atom which coagulated into a cell, or is it ruled by an Intelligence? The more I see and the more I observe, the more does this Intelligence shine behind the mystery of things. I know that I shall not fail to be treated as an abominable "final causer." Little do I care! A sure sign of being right in the future is to be out of fashion in the present. 


\section{CHAPTER III}

\section{THE PELOP厓U}

F the several insects that elect to make their home in our houses, certainly the most interesting, for the beauty of its shape, the singularity of its manners and the structure of its nests, is the Pelopæus, a Wasp hardly known even to the people whose fireside she frequents. Her solitary habits and her peaceful occupation of the premises explain why history is silent in her regard. She is so extremely retiring that her host is nearly always ignorant of her presence. Fame is for the noisy, the importunate, the noxious. Let us try to rescue the modest creature from oblivion. An extremely chilly mortal, the Pelopxus pitches her tent under the kindly sun which ripens the olive and prompts the Cicada's song; and even then she needs for her family the additional warmth furnished by our dwellings. Her usual refuge is the peasant's lonely cottage, with its old fig-tree shading the well in front of the door. She 


\section{The Pelopæus}

chooses one exposed to all the heat of summer and, if possible, boasting a capacious fireplace in which a fire of sticks is frequently renewed. The cheerful blaze on winter evenings, when the sacred yule-log burns upon the hearth, is largely responsible for her choice, for the insect knows by the blackness of the chimney that the spot is a likely one. A chimney that is not well glazed by smoke does not inspire her with confidence: people must shiver with cold in that house.

During the dog-days in July and August, the visitor suddenly appears, seeking a place for her nest. She is in no wise disturbed by the bustle and movement of the household: they take no notice of her nor she of them. Spasmodically she examines, now with her sharp eyes, now with her sensitive antennæ, the corners of the blackened ceiling, the angles of the rafters, the chimneypiece, the sides of the fireplace in particular and even the interior of the flue. Having finished her inspection and duly approved of the site, she flies away, soon to return with the little pellet of mud which will form the first layer of the edifice.

The spot which she adopts varies greatly; often it is an extremely curious one, the one 


\section{The Mason-Wasps}

positive condition being that the temperature should be mild and equable. A furnace heat appears to suit the Pelopæus' larvæ; at least, the favourite place is the chimney, on either side of the flue, up to a height of twenty inches or so. This snug shelter has its drawbacks. The smoke gets to the nests, especially during the winter, when fires are going all day, and gives them a glaze of brown or black similar to that which covers the stonework. They are so like it in appearance that they might well be taken for inequalities in the mortar which have been overlooked by the trowel. This swarthy distempering is not a serious matter, provided that the flames do not lick against the cluster of cells. That would ensure the destruction of the larvæ, stewed to death in their clay pots. But this danger appears to be foreseen; and the Pelopæus entrusts her family only to chimneys which are too wide for anything but smoke to reach their sides; she is suspicious of the narrow ones which allow the flames to fill the whole entrance to the flue.

In spite of her caution, one peril remains. While the nest is building, at a moment when the Wasp, urged by the need for laying her eggs, cannot bring herself to cease 


\section{The Pelopæus}

working, it sometimes happens that the approach to the dwelling is barred to her for a time, or even for the whole day, either by a curtain of steam rising from a stewpan or by clouds of smoke resulting from damp firewood. Washing-days are the most risky. From morning to night, the housewife keeps the huge cauldron boiling with all the odds and ends of the wood-shed: chips, bits of bark, leaves, fuel that burns with difficulty and intermittently. The smoke from the hearth, the steam from the cauldron and the reek from the wash-tub form in front of the fireplace a dense mist with very few rifts in it. I have at rare intervals surprised the Pelopæus in the presence of some such obstacle.

It is told of the Water-ouzel, the Dipper, that, to get back to his nest, he will fly through the cataract under a mill-weir. The Pelopæus is even more daring: with her pellet of mud in her teeth, she crosses the cloud of smoke and disappears behind it, henceforth invisible, so thick is the screen. A spasmodic chirring, her working-song, alone betrays the mason at her task. The building rises mysteriously behind the cloud. The ditty ceases and the Wasp emerges from the steam-flakes, fit 


\section{The Mason-Wasps}

and well, as though coming out of a limpid atmosphere. She has faced the fire, like the fabled Salamander, and she will face it all day, until the cell is built, crammed with victuals and closed.

Cases of this kind occur too seldom to satisfy fully the curiosity of a seasoned observer. I should have liked to arrange the mist-screen myself and thus to try a few experiments bearing upon the dangerous crossing; but I was a stranger, a spectator by sheer chance; and all that I could do was to trust to luck, without interfering with the washing-operations and perhaps upsetting them. What a sorry idea the housewife engaged on that grave business would have had of my intelligence if I had ventured to touch her fire in order to worry a Wasp!

"I'a pétan cièucle: little things please little minds," she would have been sure to think.

In the eyes of the peasant, to occupy one's self with such small fry is a lunatic's game, the amusement of a cracked mind.

Once and once only fortune smiled upon me; but I was not ready to profit by it. The thing took place at my own house, by my own fireside and, as it happened, on a washing-day. I had not long been ap- 


\section{The Pelopæus}

pointed to the Avignon grammar-school. It was close upon two o'clock; and in a few minutes the roll of the drum would summon me to display the properties of the Leyden jar to an audience of wool-gatherers. I was preparing to start, when I saw a strange, agile insect, with a slender body and a gourd-shaped abdomen slung at the end of a long thread, dart through the reek rising from the wash-tub. It was the Pelopæus, whom I saw for the first time with observant eyes. A novice still and anxious to become better-acquainted with my visitor, I fervently commended the insect to the watchful /care of the household, begging them not to disturb it in my absence and to manage the fire in such a way as not to inconvenience it in its plucky work of building the walls of its nest right beside the flame. My wishes were carried out religiously.

Things went better than I dared hope. On my return, the Pelopæus was continuing her mason's work behind the steam of the wash-tub, which stood under the mantel of a wide chimney. Eager as I was to witness the construction of the cells, to identify the nature of the provisions, to follow the evolution of the larvæ, all of them 


\section{The Mason-Wasps}

biological details entirely new to me, I took good care not to raise the experimental obstacles which I should not fail to set in the path of instinct to-day: a good nest was the sole object that I coveted. Therefore, so far from creating fresh difficulties for the Pelopæus, I did my utmost to reduce those which she had to overcome. I raked the fire, making it much smaller, so as to decrease the volume of smoke in the Wasp's building-yard; and for a good two hours I watched her diving through the cloud. Next day, the usual niggardly fire was burning intermittently; and there was nothing now to hamper the Pelopæus, who continued her work for some days and without further impediment completed the wellfilled nest which was the object of my wishes.

Never again, in the forty years that followed, was my fireplace honoured with such a visit; and it was only by having recourse to the more fortunate hearths of my neighbours that I was able to glean my little bit of information. Nor was it until much later that, profiting by long experience, I had the idea of turning to account the predilection of so many Bees and Wasps for their birthplace and for founding a 


\section{The Pelopæus}

family in the neighbourhood of the nest where they receive perhaps the strongest of all impressions, the first dawn of light. I took Pelopæus-nests which I had collected more or less everywhere during the winter and fixed them in different places, in my present house, which, judging by the sum total of my observations, I considered suitable, notably at the entrance to the chimney both of the kitchen and of the study. I put some in the embrasures of the windows, keeping the outside shutters closed to obtain the requisite sultriness; I stuck some to the dimly-lighted corners of the ceilings. It was in these sites of my choosing that the new generation was to hatch when summer came; it was here that it would settle: at least I thought so. Then I could have conducted in my own way the experiments which I had in mind.

My attempts invariably failed. Not one of my charges returned to the native nest; the less fickle of them contented themselves with brief visits, soon followed by a departure for good. The Pelopæus, it appears, is of a solitary and vagrant disposition: save in exceptionally favourable circumstances, she builds a lonely nest and is quite ready to change her locality from 


\section{The Mason-Wasps}

generation to generation. As a matter of fact, though this Wasp is fairly common in my village, her dwellings are nearly always scattered one by one, with no traces of any old nests near by. The place of her birth leaves no lasting recollection in the nomad's memory; and none comes to build beside the ruins of the maternal home.

For that matter, my want of success might well be due to another cause. The Pelopæus certainly is not rare in our southern towns; nevertheless she prefers the peasant's smoky house to the townsman's white villa. Nowhere have I seen her so plentiful as in my village, with its tumbledown cottages guiltless of rough-cast and burnt yellow by the sun. My hermitage is not quite so rustic as that: it is a little neater and cleaner; and there is nothing to show that my visitors did not forsake my kitchen and my study, both too sumptuous in their opinion, to go and settle somewhere near in lodgings more to their taste. And so the eagerly desired colonists, who were to have peopled my workroom crammed with books, plants, fossils and entomological cemeteries, took their departure, scorning all that scientific luxury; they went away in search of some 


\section{The Pelopæus}

dim chamber with a solitary window sporting a sprig of wall-flower in an old, cracked stew-pot. Felicities like that are reserved for the humble; and I am therefore reduced to what I have gained by an occasional piece of good luck, irrespective of any efforts of mine. The little that I have seen, in one direction and another, is after all sufficient evidence of the pluck of the Pelopæus, who, to reach her nest built in a corner of the hearth, at times passes through a cloud of steam and smoke. Would she dare to cross a thin sheet of flame? That was what I had proposed to see, if my attempts to acclimatize her in my home had met with any success.

It is obvious that, in displaying a marked predilection for the chimney as her abode, the Pelopxus is not seeking her own comfort: the site chosen means work and dangerous work. She seeks the welfare of her family. This family then, in order to prosper, must require a high temperature, such as is not demanded by the other Wasps or Bees, the Chalicodoma and the Osmia, for instance, who find sufficient shelter under a mortar dome or in the hollow of an exposed reed. Let us see what temperature the Pelopæus finds to her liking. 


\section{The Mason-Wasps}

On the side-wall, under the chimneypiece, I hung a thermometer over a Pelopæusnest. During an hour's observation, with a fire giving out a moderate heat, it fluctuated between $95^{\circ}$ and $105^{\circ} \mathrm{F}$. This temperature, it is true, does not remain the same during the long larval period; on the contrary, it varies greatly, according to the season of the year and the time of day. I wanted something better and I found it on two occasions.

My first observation was made in the engine-room of a silk-factory. The back of the boiler reached nearly to the ceiling, the space between being barely twenty inches. It was against this ceiling, right above the huge cauldron, which was always full of water and steam at a high temperature, that the Pelopæus-nest was fixed. At this spot the thermometer marked $120^{\circ}$. This degree of heat was maintained all through the year; it was only at night and on holidays that it decreased.

A country distillery furnished me with the second subject of observation. It combined two excellent conditions for attracting Pelopæi: rural quiet and the heat of a furnace. The nests therefore were numerous, fixed more or less everywhere on 


\section{The Pelopæus}

anything that came to hand, even down to the pile of account-books in which the excisemen registered their troublesome inspections of the proof-spirit. One of these, situated quite close to the still, was tested with the thermometer. It measured $I I 3^{\circ}$ of heat.

These few data prove that the larvæ of the Pelopxus are comfortable in a temperature of a hundred degrees or over, a temperature not accidental, like that produced by a fire blazing in a chimney, but constant, such as obtained by a boiler or a still. Tropical heat is favourable to the grub slumbering for ten months in its mud hole. Any seed, in order to sprout, needs a certain quantum of heat, greater or smaller according to its kind. The larva, a sort of animal seed out of which the perfect insect will come by a process of germination even more wonderful than that which turns an acorn into an oak, the larva also claims its quantum of heat. The larva of the Pelopæus can cheerfully endure a temperature that makes the baobab or the oily palm-tree sprout. What then is the origin of this chilly tribe?

A good fire on the hearth, a boiler or a furnace shedding an artificial tropical 


\section{The Mason-Wasps}

climate around them are useful windfalls, which, however, cannot be relied upon; and the Pelopæus settles in any lodging where she finds warmth and not too garish a light. The corners of a conservatory; a kitchenceiling; the embrasure of a window with closed casement and shutters, provided that these furnish some exit-hole; the rafters of a loft, where the warmth of the daily quota of sunshine is preserved by the heaped-up hay and straw; the walls of a cottage bedroom: any of these suit her, so long as the larvæ find a snug shelter in winter. This climatological expert, the daughter of the dog-days, divines the coming peril for her family, that inclement season which she herself will never see.

While she is scrupulous in her choice of a warm spot, on the other hand she is supremely indifferent to the nature of the foundation on which the nest is to be fastened. As a rule, she fixes her groupsi of cells to the stonework, whether roughcoated or not, and to the timber, whether bare or plastered; but she uses many other supports, some of which are very peculiar. Let us mention a few of these fantastic installations.

My notes speak of a nest constructed in- 


\section{The Pelopæus}

side a gourd standing on the mantelpiece of a farm-kitchen. In this narrow-mouthed receptacle the farmer used to keep his shot. As the orifice was always open and the utensil not employed at that time of year, a Pelopæus had found that the peaceful retreat suited her and had gone to the length of building on the layer of small-shot. The gourd had to be broken to extract the bulky edifice.

The same notes tell me of nests built against the pile of account-books in a distillery; in a fur cap relegated to the wall until the return of winter; in the hollow of a brick, back to back with the downy structure of a Cotton-bee; on the sides of a bag of oats; in a piece of lead tubing broken off from an old water-pipe.

I saw something more remarkable still in the kitchen at Roberty, one of the biggest farms near Avignon. It was a large room with a very wide fireplace, in which the soup for the farm-hands and the food for the cattle were simmering in a row of pots and pans. The labourers used to come in from the fields so many at a time, take their seats on benches round the table and devour the portions served to them, with the silent haste that denotes a keen appetite. To en- 


\section{The Mason-Wasps}

joy this half-hour of comfort, they would take off their hats and smocks and hang them on pegs on the wall. Short though the meal was, it lasted long enough to allow the Pelopxi to inspect the garments and take possession of them. The inside of a straw hat was recognized as a most useful retreat; the folds of a smock were looked upon as a shelter which could be turned to excellent account; and the work of building started forthwith. On rising from table, one of the men would shake his smock, another his hat, to rid it of a heap of mud that was already the size of an acorn.

When the labourers had gone, I had a talk with the cook. She told me of her tribulations: those impudent Bugs were all over the place, dirtying everything with their filth. She was chiefly concerned about the window-curtains. Dabs of mud on the ceiling, on the walls, on the chimneypiece you could put up with; but it was a very different matter when you found them on the linen and the curtains. To keep the curtains clean and dislodge the wretched things who persisted in bringing in their bits of mud, she had to shake them every day, to beat them with a bamboo. And it was all no use: next morning, work was resumed 


\section{The Pelopæus}

with equal vigour on the buildings destroyed the day before.

I sympathized with her sorrows, while greatly regretting that I could not myself take charge of the place. How gladly I would have left the Pelopæi undisturbed, though they covered every scrap of upholstery with mud; how willingly I would have let them have their way, so that I might learn what prospects there are for a nest if perched on the shifting support of a coat or a curtain! The Mason-bee of the Shrubs, ${ }^{1}$ heedless of the storm, builds on a twig; but her edifice, constructed of hard mortar, envelops the support, surrounds it on every side and becomes firmly fixed to it. The nest of the Pelopæus is a mere blob of mud, fastened to its support without any special adhesive preparation. It has no hydraulic cement which sets as soon as used, no foundations welded to the supporting base. How can such a method give proper stability? The nests which I find on the coarse canvas of corn-bags come off at the least shake, though the rough mesh of the stuff makes it easier for them to stick on: what will happen when the nests are placed on a piece of fine calico hanging

1 Cf. The Mason-bees: chap. x.-Translator's Note. 


\section{The Mason-Wasps}

perpendicularly and often flicked about, if only by the draught? To build on that strikes me as an aberration of instinct on the part of the architect, who has not yet learnt, in spite of the long lesson of the ages, how perilous are certain sites in human habitations.

Let us leave the constructor and occupy ourselves with the structure. The materials consist exclusively of wet earth, mud or dirt, picked up wherever the soil possesses the proper degree of humidity. When there is a stream in the neighbourhood, the thin clay of the banks is turned to account. But cement-works of this sort are rare or too far off in my stony region; and it is not in such a building-yard that I most frequently witness the gathering of the materials. I can watch the performance at my leisure without leaving my own garden. When a thin trickle of water runs from morning till evening in the little trenches cut in the vegetable-plots, a few Pelopæi, visitors to the neighbouring farms, soon get wind of the glad event. They come hurrying up to take advantage of the precious layer of mud, a rare discovery in this distressing time of drought. One selects a recently-watered furrow, another prefers to 


\section{The Pelopæus}

keep on the bank and settle in a workyard moistened by capillary action. They scrape and skim the gleaming, slimy surface with their mandibles while standing high on their legs, with wings aquiver and their black abdomen upraised on its yellow pedicel. No neat little housewife, with skirts carefully tucked out of the dirt, could be more adept in tackling a job so prejudicial to the cleanliness of her clothes. These mud-gatherers have not an atom of soil upon them, so careful are they to tuck up their skirts in their fashion, that is to say, to keep their whole body out of the way, all but the tips of their legs and the busy points of their mandibles. In this manner a dab of mud is collected, almost the size of a pea. Taking the load in its teeth, the insect flies off, adds a layer to its building and soon returns to collect another pellet. The same work is pursued as long as the earth remains sufficiently wet, during the hottest hours of the day, for there is always some builder looking about for mortar.

But the most frequented spot is in front of the great fountain in the village. Here there is a large trough where the people round about come to water their Mules. The constant trampling of the heavily-laden 


\section{The Mason-Wasps}

quadrupeds and the overflow of the water create a perpetual sheet of black mud which neither the heat of July nor the mighty blast of the mistral succeeds in drying. This bed of mire, so unpleasant for the passers-by, is beloved of the Pelopxi, who meet there from every part of the neighbourhood. You seldom pass before the noisome puddle without seeing some of them gathering their pellets amid the hoofs of the Mules slaking their thirst.

The places exploited are enough in themselves to tell us that the mortar is collected ready-made, fit for immediate use without any further preparation than a vigorous kneading which gets rid of the lumps and makes the whole into a homogeneous mass. Other builders in clay, the Mason-bees, for instance, scrape up the dust on the highway and moisten it with saliva to convert it into a plastic material which will harden like stone by virtue of certain chemical properties of the salivary fluid. They set to work like the bricklayer, who mixes his mortar and his plaster by adding water in small quantities. The Pelopæus does not practise this art; the secret of chemical action is denied her; and the mud is employed just as it is picked up. 


\section{The Pelopæus}

To make sure of this, I stole a few pellets from the busy collectors and, on comparing them with other pellets gathered in the same place and rolled by my own fingers, found no difference between them in appearance or in properties. The result of this comparison is confirmed by an examination of the nest. The structures of the Chalicodomæ are solid masonry, capable of resisting without any protection the prolonged action of rain and snow; those of the Pelopæi are flimsy work, devoid of cohesion and absolutely unfitted to withstand the vicissitudes of the open air. A drop of water laid upon their surface softens the spot touched and reduces it to mud again, while a sprinkling equal to an average shower turns it into pap. They are nothing more than dried slime and become slime again as soon as they are wetted.

The thing is obvious: the Wasp does not improve the mud to make it into mortar; she uses it as it is. It is no less obvious that nests of this sort are not made for out-of-doors, even if the larva were not of such a chilly humour. A shelter that keeps them under cover is indispensable, otherwise they would go to pieces at the first shower of rain. This explains, apart alto- 


\section{The Mason-Wasps}

gether from questions of temperature, why the Pelopæus has a preference for human habitations, which afford the best protection against damp. Under the mantels of our chimneys she finds at one and the same time the heat required by the larvæ and the necessary dryness for the nests.

Before receiving its final coating, which conceals the structural details, the Pelopæus' edifice does not lack elegance. It consists of a cluster of cells, sometimes arranged side by side in one row - which gives the fabric something of the look of a mouth-organ with reeds all short and all alike in size - but more often grouped in a varying number of layers placed one above the other. In the most populous nests I count as many as fifteen cells; others contain only about ten; others again are reduced to three or four, or even to one alone. The first appear to me to represent a mother's whole output of eggs; the second signify incomplete layings, deposited here and there, perhaps because better sites were found elsewhere.

The cells are not far removed from the cylindrical shape, with a diameter increasing slightly from the mouth to the base. 


\section{The Pelopæus}

They measure three centimetres ${ }^{1}$ in length, their breadth where they are widest being about fifteen millimetres. ${ }^{2}$ Their delicate surface, carefully polished, shows a series of stringy projections, running obliquely, not altogether unlike the twisted cords of certain kinds of gold-lace. Each of these strings is a layer of the edifice; it comes from the clod of mud employed on the coping of the part already built. By numbering them one can tell how many journeys the Pelopæus has taken to her mortar. I count between fifteen and twenty. For one cell, therefore, the industrious builder fetches materials something like twenty times and perhaps even oftener, for one of these cushions of mud is not always, so it seems to me, completed in a single spell of work.

The main axis of the cells is horizontal, or not far removed from it; the mouth is always turned upwards. And this must needs be so: a pot cannot hold its contents save on condition that it be not upside down. The Pelopæus' cell is nothing more than a pot destined to receive the preserved foodstuffs, a pile of small Spiders. When laid

1 1.17 inch.- Translator's Note.

2.58 inch. - Translator's Note. 


\section{The Mason-Wasps}

horizontally or slanting a little upwards, the receptacle holds its contents; but with the mouth turned downwards it would lose them. I have lingered a moment over this petty detail to call attention to a curious mistake current in the text-books. Wherever I find a drawing of a Pelopæus-nest, I see it with the orifices of the cells facing downwards. The illustrations go on and on: today's reproduces yesterday's absurdity. I do not know who was the first to perpetrate this blunder and to think of subjecting the Pelopæus to a task no less arduous than that of the vessel of the Danaides: to fill a pot turned upside down.

Built one by one, stuffed full of Spiders and closed as and when the laying demands it, the cells retain their elegant exterior until the cluster is deemed large enough. Then, to strengthen her work, the Pelopæus covers the whole with a defensive casing; she lays on the plaster with an unsparing trowel, without artistry or any of those delicate and patient finishing-touches which she lavishes upon the work of the cells. The pellet is applied just as it is brought and merely spread with a few careless strokes of the mandibles. Thus the original beauties of the structure - the 


\section{The Pelopæus}

flutings between the cells sat back to back, the corded cushions, the polished stuccoall disappear under a forbidding husk. In this final state, the nest is nothing more than a shapeless protuberance; one would take it for a great splash of mud that had been flung against the wall by accident and dried there.

We find similar methods among the Chalicodomæ. The best mason among them, after she has erected her cells on a pebble, building them in the form of turrets daintily encrusted with bits of gravel, buries her artistic work under a clumsy plaster. Why do they both give this finish and devote such fastidious care to the frontage, when the masterpiece is doomed to disappear, deluged in mortar? We do not build a Louvre and then abandon its colonnades to the unclean trowel. But we must not press the analogy too far. What do insects care about the beauty or ugliness of an edifice, provided that the larva be comfortably housed? With them we must be prepared for all the inconsistencies of the unconscious artist. 


\section{CHAPTER IV}

\section{THE AGENIÆ; THE PELOP瓜US' VICTUALS}

JUDGING only by instincts and habits, a characteristic superior to all others, we must rank not far below the builder whose nest we have been considering certain other Wasps of our country-side, Spider-hunters like the first and, like her, worthy, or perhaps even more worthy, of the title of II $\eta \lambda$ лолоós, a worker in clay or mud, a potter. My district possesses two of these ceramic artists: Agenia punctum, PANZ., and $A$. hyalipennis, ZETTERSTEDT.

With all their talent they are very frail creatures, clad in black and hardly larger than the ordinary Gnat. Their pottery amazes us when we remember the feebleness of the artisan. It surprises us even more by its regularity, which may be compared with the product of the turning-lathe. Adhering broadly to a flat base and leaning one against the other, the Pelopæus' cells, in the full elegance of the first phase, are 


\section{The Ageniæ}

merely semicylinders whose circular contour is accentuated only at the mouth; while those of the Agenix, which are almost isolated from one another and take hold of their support only at a restricted spot, retain from end to end a regular convexity, suggesting the tiny pots of a miniature set of crockery. If any one deserves the epithet of spirifex, or turner, it is the Agenia rather than the Pelopæus. No other manipulator of potter's clay possesses her dexterity.

The pots of $A$. punctum are shaped like oval jars, each smaller than a cherry-stone. Those of $A$. hyalipennis affect a conoid form, narrow at the base and wider at the mouth, like the primitive drinking-cup, the cyathus of the ancients. Both have a polished interior and a very much granulated exterior, the maker allowing the little mouthful of mortar which' she has brought to project outside, without seeking to level it, as she does so carefully upon the inner wall. These granulations are the equivalent of the slanting fillets left by the Pelopæus. No rough-cast, no plaster is applied to conceal the pretty bit of earthenware; no reinforcement of casing is added. Such as it was when the potter moulded the neck, such 


\section{The Mason-Wasps}

it remains after it has received its lid and its little Spider with an egg laid upon her side. The Agenia's urns then, notwithstanding their brittleness, are left entirely unprotected, whether they be placed end to end in a winding row or grouped in a confused cluster.

Nevertheless, the mother displays a precaution unknown to the Pelopæus. A drop of water placed inside the latter's cell quickly spreads and disappears, soaking the walls. In an Agenia's cell it remains at the point touched, without penetrating the thickness. The urn therefore is glazed on the inner surface, like our ordinary pots, which are made watertight by the silicate of lead furnished by the potter's galena. The waterproofing employed cannot be other than the Agenia's saliva, an agent which is anything but plentiful, because of the insect's exiguous dimensions, and so it is applied only on the side. Indeed, if I stand a cell on a drop of water, I see the moisture at once spread from bottom to top and turn the vessel into pulp, until nothing is left but a thin inner layer, which is less yielding.

I do not know where the Ageniæ get their materials. Do they follow the Pelopæus' 


\section{The Ageniæ}

custom and collect loam ready prepared, wet earth, mud or naturally plastic clay; or, copying the method of the Mason-bees, do they use cement scraped together atom by atom and converted into paste with the saliva? Direct observation has failed to tell me anything in this respect. From the colour of the cells, which are now red, like the soil of our stony expanses, now whitish, like the dust of the highways, now greyish, like certain chalk-beds in the neighbourhood, I see plainly that the material for the pots is collected everywhere indifferently, but I am unable to determine whether, at the actual moment of collection, it is paste or powder.

I incline, however, to the latter alternative, because of the impermeable inner surface of the cells. Earth already soaked with natural moisture would not readily absorb the Agenia's saliva and could not acquire the watertight qualities which I find that it possesses. This peculiarity makes it highly probable that the cement is collected dry and that the insect mixes it in order to turn it into plastic clay. Then how are we to explain the outside of the pot, which melts upon contact with a drop of water, and the inside, which remains intact? 
The Mason-Wasps

Very simply: for the outside materials the potter uses only the water with which she slakes her thirst from time to time; for the inside materials she uses pure saliva, a precious agent which has to be thriftily employed, so that she may equip her family with a sufficiency of earthenware. To construct her pots, the Agenia must possess two separate fluid-reservoirs: the crop, a bottle which is filled with spring-water; and the gland, a phial in which the watertight chemical product is sparingly elaborated.

The Pelopæus knows nothing of these scientific methods. To the mud collected ready-made she adds nothing that develops resisting-powers later; when attacked by water, her cells quickly become soaked and allow the moisture to ooze through to the inside. Hence probably, in her case, the necessity for a thick casing of plaster to protect the too permeable dwelling. Each potter has her portion: the giantess, the rough covering of loam; the divarf, the thin coating of varnish.

Despite their inner glaze, the Agenia's cells are too readily affected by water and moreover too fragile to remain exposed to the open air with impunity. They need a shelter quite as badly as those of the 


\section{The Ageniæ}

Pelopæus. This shelter 'is found in all manner of places, excepting our houses, where the frail potter very rarely takes refuge. A tiny cavity under the stump of a tree; a hole in some wall or other, exposed to the sun; an old Snail-shell under a heap of stones; a Capricorn's disused burrow bored in the oak; an Anthophora's ${ }^{1}$ deserted dwelling; a fat Earth-worm's mineshaft opening on a dry bank; the hole whence the Cicada ${ }^{2}$ has emerged: anything, in short, suits her, provided that the accommodation be sheltered from the rain. Once only did Agenia punctum, who is more frequent than the other, pay me a visit. She had established her collection of pots in some little paper bags lying on the shelves of a green-house and intended to hold seeds. This nest-building on a sheet of paper reminded me of the Pelopæus confiding her cells to the books in a distillery or the curtains of a window. Indifferent to the nature of the support for their nests, both potters sometimes choose very curious sites.

1 For the various species of Burrowing Bees known as the Anthophorx, cf. Bramble-bee and others: chap. vii. et passim.-Translator's Note.

2 For the Cicada, or Cigale, cf. The Life of the Grasshopper, by J. Henri Fabre, translated by Alexander Teixeira de Mattos: chaps. i. to v.-Translator's Note. 


\section{The Mason-Wasps}

Now that we know the provision-jar, let us ascertain what it contains. The Pelopæus' larvæ are fed on Spiders, a diet likewise dear to the Ageniæ and to the Pompili. ${ }^{1}$. The game does not lack variety, even in the same nest and the same cell. Any Spider may form part of the ration, provided that her dimensions do not exceed the capacity of the jar. My abstracts of victuals mention the following genera: Epeira, ${ }^{2}$ Segestria, Clubionus, ${ }^{3}$ Attus, Theridion and Lycosa; ${ }^{4}$ and the list could no doubt be extended, were it worth while to continue the bill of fare. The Epeiræ are most numerous. Those recurring most frequently belong to the following species: E. diadema, scalaris, adianta, pallida and angulata. The Diadem Epeira, or Cross Spider, ${ }^{5}$ with three crosses of white dots on her back, is the dish that occurs oftenest.

I should hesitate to regard this frequency

1 The Pompilus, or Ringed Calicurgus, is a Hunting Wasp, feeding her young on Spiders. Cf. The Life and Love of the Insect: chap. xii.- Translator's Note.

2 For the Epeirx, or Garden Spiders, cf. The Life of the Spider: chaps. ix. to xiv.-Translator's Note.

${ }^{3}$ One of the Tube-weaving Spiders.-Translator's Note.

${ }^{4}$ For Theridion lugubre and the Narbonne Lycosa, or Black-bcllied Tarantula, cf. The Life of the Spider: chap. i.- Translator's Note.

${ }^{5} \mathrm{Cf}$. The Life of the Spider: chaps. vi. and vii.-Translator's Note. 


\section{The Pelopæus' Victuals}

as indicating a special predilection of the Pelopæus for this kind of game. In her hunting-trips the Wasp does not go far from her home; she vists the old walls near by, the hedges, the little gardens all around and captures whatever offers. Now in these conditions the Cross Spider happens, at the nesting-period, to be the commonest. Every reed-fenced garden-patch in front of the rough cottage beloved by the potter, every hawthorn-hedge surrounding a cabbage-plot shows me the Spider with the pontifical cross weaving her net or waiting for her prey in the centre of her web. If I need a Spider for my studies, I am certain of finding the Diadem Epeira within a few steps of my house. That much keener investigator, the Pelopæus, must easily effect this kind of capture; and this, it seems to $m e$, is the reason why that particular morsel predominates in the provision-store.

If the Epeira, the habitual foundation of the meal, happen to be lacking, any other Spider is regarded as adequate, even when she belongs to a very different group. We have here the wise eclecticism of the $\mathrm{Cra}$ bro-wasps ${ }^{1}$ and Bembeces, who welcome any

1 A family of Digger Wasps of whom the larger species burrow in the ground and the smaller in the pith of plants or in rotten wood.-Translator's Note. 


\section{The Mason-Wasps}

niember of the Fly clan, provided that the prey be not disproportionate to the huntress' strength. We should be wrong, however, to erect this indifference into too absolute a principle: there is reason to believe that the Pelopæus recognizes different qualities of nourishment and flavour between one Spider and another. A more fastidious expert than Lalande, ${ }^{1}$ with his legendary passion for plump, nutty Spiders, she must rate this species more highly than that; and there are some which she must absolutely despise. These include the House Spider (Tegenaria domestica), who weaves her cobwebs in the corners of our houses.

On the kitchen-ceiling and on the rafters of the granary this Spider is her near neighbour: the silken lair stretches in close proximity to the earthen nest. Instead of expeditions in the neighbourhood, a little patrolling of the actual premises where she has settled down would provide the Pelopæus with abundant sport, for there is game swarming at her very door. Why

${ }^{1}$ Joseph Jérôme Le Français de Lalande (1732-1807), the astronomer. Even after he had achieved his reputation, he sought means, outside the domain of science, to make himself talked about and found these in the display partly of odd tastes, such as that for eating Spiders and caterpillars, and partly of atheistical opinions.-Translator's Note. 


\section{The Pelopæus' Victuals}

does she not profit by this plenty? The dish is not to her liking; and it would be very difficult to tell the reason why. The fact remains that, in all my stock-taking of victuals, I have never found the House Spider among the provisions, although the species, if captured young, would seem to fulfil the required conditions. This disdain is a pity both for our sake and for the Pelopæus'; for ours, in the first place, because we should otherwise possess, inside our dwellings, an inspector of ceilings whose duty it would be to exterminate the spinners of cobwebs that cause the housewives such trouble; next, for the sake of the Pelopæus, who, once inscribed on the hallowed roll of useful insects, would enjoy an established reputation and receive a friendly welcome in the farm-house, instead of being driven out when too lavish with her mud.

The Spider, armed with poison-fangs, is a dangerous quarry to tackle; when of fair size, she demands of her adversary an audacity and above all a tactical skill which the Pelopæus, it seems to me, does not fully possess. Moreover, the small diameter of the cells would not admit a bulky prey, such as the Tarantula hunted by the Ringed 


\section{The Mason-Wasps}

Calicurgus. ${ }^{1}$ The Calicurgus deposits her corpulent victim in a cavern obtained without labour in the old plaster at the foot of a wall; the Pelopæus places hers in a jar, a laborious construction whose capacity has to be reduced to suit the larva. The Pelopæus, therefore, hunts game of moderate size, smaller than one would at first expect from the insect's vigorous appearance. If she encounters a species that is apt to become plump, she always selects a young one. This happens in the case of the Cross Spider, who, when full-grown, with her belly swollen with eggs, almost rivals the Calicurgus' Tarantula and who is admitted to the provision-jar only when of niggardly dimensions, very different from those which maturity will bring. For the rest, the size varies, between one specimen and another, by a hundred per cent and more. The essential point is that the quarry can be stored in the narrow jar. This variation in the size of the items provided leads to corresponding variations in their number. One cell is stuffed with a dozen Spiders; another contains only five or six. The average number is eight. The nurseling's sex must of a surety play its part,

1 Or Pompilus: vide supra.-Translator's Note. 


\section{The Pelopæus' Victuals}

as with the other Wasps, in regulating the luxuries of the table.

The culminating feature in the biography of any hunting insect is the method of attack; and so I did my utmost to observe the Pelopæus at grips with her quarry. My patient waits in front of her favourite hunting-grounds, old walls and bramble-thickets, were not crowned with any great success. I have seen the Pelopæus fall suddenly upon the Spider madly fleeing and clasp and carry off her victim almost without delaying her flight. The other game-hunters alight on the ground, solemnly make their fastidious preparations and distribute their lancetstrokes with the calm deliberation which a delicate operation demands. The Pelopæus darts forward, seizes her prey and makes off, very much as the Bembeces do. There is reason to believe, so sudden is the rape, that she makes use of her sting and her mandibles only during the flight, on her journey home. This fierce procedure, which is incompatible with scientific surgery, explains even better than the narrowness of the cells her preference for Spiders of small dimensions. A sturdy prey, armed with its two poison-fangs, would constitute a deadly peril to the ravisher disdainful of precau- 


\section{The Mason-Wasps}

tions. The lack of artifice calls for a feeble victim. It also makes us suspect that the Spider so hastily set upon is killed.

Indeed, I have over and over again armed my eyes with a magnifying-glass and scrutinized the contents of cells whose eggs had not yet hatched, a proof that the provisions were of recent date: there is never a quiver of either palpi or tarsi in the victims stored away. It is only with difficulty that I manage to preserve them: in ten days' time, more or less, I see them grow mouldy and putrefy. The Spiders, therefore, are dead, or very nearly so, when they are potted by the Pelopæus. Is the skilful paralysis which the Calicurgus practises upon the Tarantula, who keeps fresh for seven weeks, unknown to the Pelopæus, or is it impracticable in the fierceness of the attack? Are we, in her case, dealing not with a delicate practitioner, who is able to abolish movement without destroying life, but rather with a brutal sacrificer, who, to deprive her victims of their power of movement, kills them? Everything in their withered aspect and their rapid decay assures us that this is so.

The evidence does not surprise me: we shall see, as we go on, other victimarii in- 


\section{The Pelopæus' Victuals}

flict death instantly with a stroke of the stiletto, delivered with a science of slaughter no less astonishing than the science of the paralysers. We shall see the reasons that call for these complete murders and we shall recognize, under other aspects, the profound anatomical and physiological knowledge which a rational action would demand in order to rival the unconscious action of instinct. As for the necessity of killing her Spiders under which the Pelopæus labours, I find it impossible even to suspect the cause.

What I do see, without any lengthy investigations, is the logical method whereby the Pelopæus makes the most of the corpses threatened with speedy putrefaction. To begin with, each cell contains a number of victims. The carcase actually attacked by the larva, ground, between its mandibles, abandoned and attacked at another point, soon becomes a shapeless and disorganized mass, more liable than ever to putrefy. But it is small and is therefore consumed at a single sitting, before decomposition overtakes it; for once the larva has bitten into a Spider it does not turn elsewhere for food. The others therefore remain intact, which is enough to preserve them in a condition of 


\section{The Mason-Wasps}

suitable freshness during the brief period of nourishment. The numerous items composing the ration, consumed in order, one by one, are thus preserved for some days, notwithstanding that they are corpses.

Imagine, on the other hand, a single item, big enough to furnish the whole banquet; the conditions would become detestable. Nibbled here and there, the generous morsel, with its many wounds, would become a fatal mess of putrescence long before it was finished; it would poison the grub with the serum resulting from the wounds. A dish of this kind, single and sumptuous, demands, as a preliminary, the maintenance of organic life, together with the abolition of all movement, in a word, paralysis. It also demands, on the consumer's part, a special art of eating, an art that respects the more essential and attacks the less essential by degrees, as the Scolix and Spheges ${ }^{1}$ have shown us. For reasons which escape me, the Pelopæus is unacquainted with the paralysers' art, nor does her larva know how a bulky piece of game may be consumed without danger. She is therefore very happily inspired when she

${ }^{1}$ For the Scolia, cf. The Life and Love of the Insect: chap. xi.; for the Sphex, cf. The Hunting Wasps: chaps. iv. to x.- Translator's Note. 


\section{The Pelopæus' Victuals}

provides her family with a large number of small game. The restricted capacity of the store-houses is not the main motive that dictates her choice: there would be nothing to deter the potter from making bigger pickle-jars, were there any advantage to be gained. The preservation of dead victuals is of the foremost consequence; and, to achieve it within the brief limits of the feeding-period, the huntress fills her bag with none but the smaller Spiders.

Better still : if I open cells that have been recently closed, I always find the egg, not on the surface of the heap, on the last Spider supplied, but right at the bottom, on the piece earliest in date, the first to be stored. Whenever I witness the start of the provisioning, I see the egg lying on the single Spider wherewith the cell is then provided. There is no exception to the rule: the Pelopxus at once fixes her egg on the first morsel served up, before resuming the chase to complete the ration. The Bembeces deal similarly with their dead Flies: the first carcase stowed away receives the egg.

But this conformity of habits goes no farther. The Bembeces continue to bring provisions day by day, as the larva increases 


\section{The Mason-Wasps}

in size, a method easily practised in a burrow closed with a mere screen of loose sand, through which the mother passes easily in either direction. The Pelopæus has not the same facilities of ingress and egress: once the earthen jar is closed and sealed, she would have, in order to reenter the cell, to break the lid, which is now dry and would offer a resistance out of all proportion to the means at the disposal of the Wasp accustomed to handling fresh mud. Moreover, each of these laborious burglaries would have to be followed by a rebuilding, which also would be an arduous task.

It is not therefore the Pelopæus' practice to feed her offspring day by day; and the hoard of victuals is completed as swiftly as possible. If game be not abundant, if the atmospheric conditions be difficult, several days are required to fill the cell thoroughly. In favourable weather, an afternoon is sufficient. No matter what time the hunting may take, long or short according to circumstances, the laying of the egg at the bottom of the cell, on the first piece served, is a happy device on whose excellence I have already laid stress in my history of the Odynerus. The victuals provided for a cell 


\section{The Pelopæus' Victuals}

fill it to the brim and are stacked in the order of acquisition, with the Spiders earliest in date at the bottom and the more recent on the surface. No subsidence, which would lead to a mixture of fresh game and high, is possible, because of the game's long legs, which in most cases scrape against the walls of the cell with their stiff hairs. The larva, at the bottom of the heap and, moreover, intent upon the morsel attacked, thus proceeds from the oldest to the less old and always finds in front of its teeth, until the end of the meal, victuals that have not had time to spoil by decomposition.

The egg is laid indifferently upon a large joint or a small, according to the chances of the first capture. It is white, cylindrical, slightly curved and measures three millimetres in length, with a diameter of rather less than one millimetre. ${ }^{1}$ The spot that receives it on the Spider's body varies hardly at all; it is at the beginning of the abdomen, towards the side. The new-born larva, as is usual with the Hunting Wasps, takes its first bite at the point where the pole of the egg containing the head was fixed. Thus, for its first mouthfuls, it has the juiciest and tenderest part, the Spider's

1.177 by .039 inch. - Translator's Note. 
The Mason-Wasps

plump belly. Next comes the thorax, abounding in muscular tissues, and lastly the legs, dry morsels, but not despised. Everything goes down, from the best to the coarsest; and, when the meal is finished, there is practically nothing left of the whole heap of Spiders. This life of gluttony lasts for eight to ten days.

The larva then works at its cocoon, which consists at first of a sack of pure, perfectly white silk, an extremely delicate sack, affording little protection to the recluse. This is only a woof, destined to become a better stuff, not by additional weaving, but by the application of a special lacquer. The spinner is a worker in oiled silk.

In the spinning-mills of the carnivorous Wasps, two methods of manufacture are employed to give the silken fabric greater toughness. On the one hand, the fabric is encrusted with numerous grains of sand, which produces an almost mineral shell wherein the silk has no other function than to serve as a cement for the stony materials. That is how the Bembeces, the Stizi, the Tachytes and the Palari work. On the other hand, the larva elaborates in its 


\section{The Pelopæus' Victuals}

stomach, in its chylific ventricle, a liquid varnish which it disgorges into the meshes of a rudimentary tissue of silk. Directly it trickles into the web, the varnish hardens and becomes a lacquer of exquisite daintiness. The larva next ejects at the base of the cocoon, in the form of a hard stercoral plug, the residue of the chemical process accomplished in its stomach for the elaboration of the varnish. This method is that of the Spheges, the Ammophilæ and the Scoliæ, who varnish the inner wrapper of their multiple cocoons; and of the Crabrowasps, the Cerceres and the Philanthi, ${ }^{1}$ whose delicate cocoon consists of only a single thickness.

The Pelopæus adopts this last procedure. When finished, her work is an amber-yellow fabric suggesting the outer skin of an onion in fineness, colour, transparency and the rustling sound which it emits when fingered. Relatively long in comparison with its width, as is demanded by the ca-

1 For the Cerceris, cf. The Hunting Wasps: chaps. i. to iii; for the Philanthus, or Bee-eating Wasp, cf. Social Life in the Insect World: chap. xiii. Some of the other Wasps mentioned above will form the subject of chapters in a later volume of this series entitled More Hunting Wasps. - Translator's Note. 


\section{The Mason-Wasps}

pacity of the cell and the slender form of the future insect, the cocoon is rounded at the top and suddenly truncated at the base, which is rendered hard and opaque by the stercoral plug, the by-product of the lacquer-factory.

The hatching-period varies, of course, according to the temperature and also according to certain conditions which I am not yet in a position to specify. One cocoon, woven in July, gives birth to the perfect insect in the course of August, two or three weeks after the larva's period of activity; another, dating from August, opens a month later, in September; a third, no matter what its date of origin during the summer quarter, goes through the winter and does not burst until the end of June. By combining the birth-certificates recorded, I seem to distinguish three generations in the year, generations which are often but not invariably realized. The first appears at the end of June: this is the one whose cocoons have gone through the winter; the second is seen in August and the third in September. So long as the very hot weather lasts, evolution is rapid: three or four weeks suffice to complete the Pelopæus' cycle. When September arrives, the fall in 


\section{The Pelopæus' Victuals}

temperature puts an end to these precocious broods; and the last larvæ have to wait for the return of the hot weather before they can undergo their transformation. 


\section{CHAPTER V}

\section{ABERRATIONS OF INSTINCT}

$\mathrm{SO}$ far as the Pelopæus is concerned, my $S$ part as an observer is concluded, a part of no great interest, I am the first to admit, if we limit its scope merely to the data which it is able to supply. That the insect frequents our dwellings, that it builds a mud nest victualled with Spiders, that it weaves itself a bag which looks as it it were cut out of an onion-skin: all these details matter to us but little. They may please the collector who zealously sets down everything, down to the nervation of a wing, in order to throw a little light on his systematic arrangements; but the mind nourished with more serious ideas sees nothing in all this but the food of an almost puerile curiosity. Is it really worth while to spend our time, the time which escapes us so swiftly, this stuff of life, as Montaigne calls it, in gleaning facts of indifferent moment and of highly contestable utility? Is it not childish to enquire so minutely into an insect's actions? Too many interests of a graver 


\section{Aberrations of Instinct}

kind hold us in their grasp to leave us any leisure for these amusements. That is how the harsh experience of age impels us to speak; that is how I should conclude, as I bring my investigations to a close, if I did not perceive, amid the chaos of my observations, a few gleams of light touching the loftiest problems which we are privileged to discuss.

What is life? Will it ever be possible for us to trace it to its sources? Shall we ever be permitted to excite, in a drop of albumen, the uncertain quiverings which are the preludes of organization? What is human intelligence? In what respect does it differ from animal intelligence? What is instinct? Are these two mental aptitudes irreducible, or can they both be traced back to a common factor? Are the species connected with one another, are they related by evolution? $\mathrm{Or}$ are they, as it were, so many unchangeable medals, each struck from a separate die upon which the tooth of time has no effect, except to destroy it sooner or later? These questions are and always will be the despair of every cultivated mind, even though the inanity of our efforts to solve them urges us to cast them into the limbo of the unknowable. 


\section{The Mason-Wasps}

The theorists, proudly daring, have an answer nowadays for every question; but, as a thousand theoretical views are not worth a single fact, thinkers untrammelled by preconceived ideas are far from being convinced. Problems such as these, whether their scientific solution be possible or not, require an enormous mass of wellestablished data, to which entomology, despite its humble province, can contribute a quota of some value. And that is why I am an observer, why, above all, I am an experimenter.

It is something to observe; but it is not enough: we must experiment, that is to say, we must ourselves intervene and create artificial conditions which oblige the animal to reveal to us what it would not tell if left to the normal course of events. Its actions, marvellously contrived to attain the end pursued, are capable of deceiving us as to their real meaning and of making us accept, in their -linked sequence, that which our own logic dictates to us. It is not the animal that we are now consulting upon the nature of its aptitudes, upon the primary motives of its activity, but our own opinions, which always yield a reply in favour of our cher-

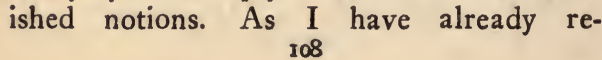




\section{Aberrations of Instinct}

peatedly shown, observation in itself is often a snare: we interpret its data according to the exigencies of our theories. To bring out the truth, we must needs resort to experiment, which alone is able to some extent to fathom the obscure problem of animal intelligence. It has sometimes been denied that zoology is an experimental science. The accusation would be well-founded if zoology confined itself to describing and classifying; but this is the least important part of its function: it has higher aims than that; and, when it consults the animal upon some problem of life, its method of questioning lies in experiment. In my own modest sphere, I should be depriving myself of the most potent method of study if I were to neglect experiment. Observation sets the problem; experiment solves it, always presuming that it can be solved; or at least, if powerless to yield the full light of truth, it sheds a certain gleam over the edges of the impenetrable cloud.

Let us return to the Pelopæus, to whom it is time to apply the experimental method. A cell has recently been completed. The huntress arrives with her first Spider. She stores it away and at once fastens her egg upon the Spider's belly. She sets out on a 


\section{The Mason-Wasps}

second trip. I take advantage of her absence to remove with my tweezers from the bottom of the cell the head of game and the egg. What will the insect do on its return, confronted with this empty cell, this cell no longer containing the egg, the sole object of her industry as a potter and her skill as a huntress?

The disappearance of the egg must be obvious to the Wasp who has been robbed of it, if her poor intelligence possess so much as the rudimentary gleam that enables us to distinguish between a thing's presence and its absence. The egg, were it alone, being of small dimensions, might escape the mother's vigilance; but it lies upon a comparatively bulky Spider, of whose presence the Pelopxus, on returning to the nest, is undoubtedly apprised by her sense of touch and sight when she deposits the second victim beside the first. If this big object be missing, the egg is missing likewise, so the most elementary trace of reason that it is possible to conceive ought to tell her. Once more, what will the Pelopæus do when confronted with her cell, where the absence of the egg henceforth renders the bringing of provisions useless and absurd, unless and until she repairs the loss by laying a second 


\section{Aberrations of Instinct}

egg? She will do precisely what we have already seen in the Mason-bee of the Sheds, but under less striking conditions: she will act absurdly and wear herself out uselessly.

What she does is to bring a second Spider, whom she stores away with the same cheerful zeal as though nothing untoward had occurred; she brings a third, a fourth and others still, each of whom I remove during her absence, so that every time that she returns from the chase the warehouse is found empty. For two days the Pelopæus' obstinacy in seeking to fill the insatiable jar persisted; for two days my patience in emptying the pot as she stocked it was equally unflagging. With the twentieth victim, persuaded, perhaps, by the fatigue of expeditions repeated beyond all measure, the huntress considered that the game-bag was sufficiently supplied; and she began most conscientiously to close the cell which contained absolutely nothing.

The Mason-bees whose cups I used to empty as and when they brushed off the pollen-dust and disgorged the honey-paste gave proof of similar inconsistencies: I would see them laying the egg in the empty cell and then closing the cell as though the provisions were still there. One point alone 


\section{The Mason-Wasps}

used to cause me some anxiety; my plug of cotton-wool left behind it, on the wall against which it rubbed, a smear of honey whose smell might deceive the insect by concealing the absence of the victuals. The coarser sense of touch was dumb while the finer sense of smell continued to speak. In the case of the famous statue of which Condillac ${ }^{1}$ tells us, the sole stimulant of mental activity was the scent of a rose. The insect's intelligence is certainly very differently equipped; nevertheless we may ask ourselves whether, in a Bee, the scent of the honey would not be so far predominant as to cheat other impressions. This, at all events, would explain the laying of the egg in a cell containing no provisions, but still full of their good smell; it would explain the scrupulous sealing of the cell in which the larva is doomed to die of starvation.

To avoid those foolish objections, the

1 Etienne Bonnot de Condillac, Abbé de Mureaux (17151780), the leading exponent of sensual philosophy. His most important work is a Traité des sensations, in which he imagines a statue organized like a man and endows it with the senses one by one, beginning with that of smell. He argues by a process of imaginative reconstruction that all human faculties and all human knowledge are merely transformed sensations, to the exclusion of any other principle; in short, that everything has its source in sensation: man is nothing but what he has acquired.-Translator's Note. 


\section{Aberrations of Instinct}

last resource of an opponent at bay, I should therefore like something better than the absurd action of the Mason-bees. And this the Pelopæus has just given us. Here we have no fragrant smear left behind by the victuals withdrawn, no vestige than can conceal the absence of provisions from the mother. The Spider whom my tweezers are about to seize at the bottom of the cell leaves no trace of her temporary sojourn, nor does the egg extracted with the first morsel, so that the Wasp cannot fail to be apprised of the void created in her cell, if she be capable of being apprised of anything. It makes no difference; nothing alters her habitual course of action. During two days, she brings a score of items, one by one, as each preceding item is removed; the stubborn hunt is prolonged, on behalf of an egg which has been absent from the outset; and at length the door of the cell is closed with the same care as under normal conditions.

Before considering the inferences to be drawn from this odd behaviour, we will record an even more striking experiment, also made at the Pelopæus' expense. I have described how, when the group of cells is completed, the insect plasters its 


\section{The Mason-Wasps}

nest, covering it with a thick rind of mud under which all the elegance of the pottery disappears. I surprise a Pelopæus at the moment when she is spreading her first pellets to form an outer casing. The nest is fastened to a wall coated with mortar. The idea occurs to me to take it away, in the vague hope of beholding something new. And something new there is, nay more, something so absurd that one would never have dared to foresee it. Let me begin by explaining that naught remains of the nest, when I have removed it and put it in my pocket, except a thin, broken line, marking the circumference of the clod of mud. Within this ring, save for a few fragments of mud, the wall has resumed the whiteness of its coat of mortar, a very different colour from that of the nest, which is an ashen grey.

The Pelopæus arrives with her load of clay. Without any hesitation that I can perceive, she alights on the deserted spot and deposits her pellet there, spreading it slightly. The operation would have been conducted no differently on the nest itself. Judging by the quiet and zealous way in which the Wasp is working, there is no doubt but that she really believes herself to be 


\section{Aberrations of Instinct}

plastering her house, whereas she is merely plastering its uncovered support. The new colour of the site and its flat surface, replacing the prominence of the vanished clod, fail to apprise her that the nest is gone.

Can this be a temporary distraction, a blunder due to the Wasp's excessive eagerness for work? She will change her mind, no doubt, perceive her mistake and discontinue her futile labours. But no: I see her coming back thirty times in succession. At each trip she brings a globule of mud, which she applies, without making a single error, inside the circumference formed by the line of clay which the base of the nest has left on the wall. Her memory, which tells her nothing of the colour, shape or prominence of the nest, is surprisingly faithful in matters of topographical detail: it knows nothing of essentials but is thoroughly acquainted with accessories; topographically speaking, the nest is there; the structure, it is true, is missing, but there is the supporting base; and that, it appears, is enough; at any rate, the Pelopæus is lavish of her exertions in bringing mud to plaster the surface on which the structure no longer stands.

In the old days, the Mason-bees used to 


\section{The Mason-Wasps}

surprise me greatly with their tenacious memory of the spot where the pebble lay supporting their nest and with their lack of perspicacity in all that concerned the nest itself, which was replaced by another, quite different nest without making them interrupt the work already begun. The Pelopæus outdoes them in these aberrations: she gives the last strokes of the trowel to an imaginary dwelling, of which nothing but the site remains.

Has she, as a matter of fact, a more obtuse intellect than the dome-builder? The entomological tribe seems hardly to swerve from a common stock of aptitudes; those whom we consider the most richly endowed, on the evidence of actions normally accomplished, show themselves as limited as the rest when the experimenter disturbs the current of their instincts. It is probable that the Mason-bee would have committed the same absurdities as the Pelopæus, had I thought of subjecting her, at a propitious time, to a similar test. A plasterer by profession, she would, like the other, have plastered the base of the nest removed from the pebble at the right moment. My confidence in the glimmer of reason which the makers of theories attribute to the animal 


\section{Aberrations of Instinct}

is so greatly shaken that I do not regard my unflattering opinion of the Mason-bee as rash.

Thirty times, I said, in my presence did the artist in earthenware lay and then spread her pellet of mud upon the bare wall, thinking that she was applying it to the nest itself. Sufficiently informed by this long perseverance, I left the Pelopæus still busy at her futile task. Two days later, I inspected the plastered site. The coating of mud did not differ from that shown by a finished nest.

I have suggested that the insect's rudimentary intelligence has practically the same limitations everywhere. The accidental difficulty which one insect is powerless to overcome, in default of a gleam of judgment, any other, no matter what its genus or species, will be equally unable to overcome. To vary the evidence, I will borrow my next example from the Lepidoptera. ${ }^{1}$

The Great Peacock ${ }^{2}$ is the largest Moth of our district. Her caterpillar, which is yellow-hued, with turquoise-blue spots sur-

${ }^{1}$ The order of insects consisting of the Butterflies and Moths. - Translator's Note.

2 Cf. The Life of the Caterpillar, by J. Henri Fabre, translated by Alexander Teixeira de Mattos: chap. xi.Translator's Note. 


\section{The Mason-Wasps}

rounded by black hairs, spins itself, at the foot of the almond-trees, a robust cocoon whose ingenious construction has long been celebrated. At the moment of her deliverance, the Mulberry Bombyx ${ }^{1}$ has in her stomach a particular solvent which the newborn Moth disgorges against the wall of the cocoon to soften it, to dissolve the gum that sticks the threads together and in this way to force an exit by the mere pressure of her head. With the aid of this reagent, the recluse is able triumphantly to attack her silken prison at the fore-end, the rear-end or the side, as I discover by turning the chrysalis in its cocoon, which I slit with a pair of scissors and then sew up again. Whatever the spot to be perforated for the emergence, a spot which my intervention varies at will, the liquid disgorged promptly soaks into and softens the wall, whereupon the captive, struggling with her fore-limbs and pushing her forehead against the tangle of unstuck threads, makes herself a passage with the same ease as in her natural liberation.

The Great Peacock is not endowed with this method of delivery by means of a solv-

1 Bombyx mori, the Moth of the Silkworm.-Translator's Note. 


\section{Aberrations of Instinct}

ent; her stomach is incapable of preparing the corrosive calculated to destroy, at any point, the defensive enclosure which is now a prison-wall. Indeed, if I reverse the chrysalis in its cocoon, opened and then closed with a few stitches, the Moth always dies, being powerless to free herself. When the point to be forced is changed, the release becomes impossible. To emerge from this shell, a genuine strong-box, a special method is therefore necessary, one having no relation to the chemical method of the Mulberry Bombyx. Let me describe, as others have done before me, how things happen.

At the fore-end of the cocoon, a conical end, whereas the other is rounded, the threads are not glued together; every elsewhere, the silken web is cemented with a gummy product that turns it into a stout, waterproof parchment. Those front threads, which are almost straight, converge at their free end and form a coneshaped series of palisades, having as their common base the circle where the use of the gummy cement is suddenly discontinued. The arrangement can best be compared with the mouth of an Eel-pot, which the fish readily enters by following the funnel of 


\section{The Mason-Wasps}

osier-switches, but from which the imprudent one cannot get out again, because the narrow passage closes its palisade at the least effort to push through.

Another very accurate comparison is provided by the Mouse-traps with an entrance consisting of a bunch of wires arranged in a truncated cone. Attracted by the bait, the rodent enters the orifice of the trap, enlarging it with a gentle thrust; but, when it becomes a question of departure, the wires, at first so tractable, become an insuperable barrier of halberds. Both devices permit entrance and forbid exit. If we invert the arrangement of the conical palisade, making it point outwards from within, its action is reversed: exit is permitted and entrance forbidden.

This is the case with the Great Peacock's cocoon, which has a slight improvement to its credit: its mouth, shaped like the Eel-pot or Mouse-trap aforesaid, is formed of a numerous series of cones, fitting one within the other and overlapping. In order to emerge, the Moth has only to push her head in front of her; the several rows of uncemented threads yield without difficulty. Once the recluse is liberated, these threads resume their position, so that there is no- 


\section{Aberrations of Instinct}

thing outside to show whether the cocoon is empty or inhabited.

Easy exit is not enough: there must also be an inviolable refuge during the labour of metamorphosis. The cell whose door is open for exit must have the same door closed against entrance, so that no evilminded one may make his way inside. The mechanism of the Eel-pot's mouth admirably fulfils this condition, which is as necessary to the safety of the Great Peacock as the first. To enter through the multiple fences of converging threads, which constitute a more effectual obstacle the harder they are pushed, would be impossible to any creature that might bethink itself of attempting to violate the dwelling. I am well-acquainted with the secrets of this lock, which contrives, like any fine piece of workmanship, to combine simple means with important results; and yet I always stand amazed when, with an open cocoon in my fingers, I try to pass a pencil through the entrance. When pushed outwards from within, it passes immediately; when pushed inwards from without, it is invincibly checked.

I am lingering over these details to show the importance which the good construction 


\section{The Mason-Wasps}

of her palisade of threads possesses for the Great Peacock. If ill-ordered, entangled and therefore intractable when pushed, the series of boxed cones will offer an insurmountable resistance and the Moth will perish, a victim of the caterpillar's imperfect art. If constructed with mathematical accuracy, but with sparse rows of threads in insufficient numbers, it will leave the retreat exposed to dangers from without and the chrysalis will become the prey of some intruder, of whom there are many in search of somnolent nymphs, forming easy victims. For the caterpillar, therefore, this doubleacting mouth is a work of the highest importance. It has to expend upon it all that it possesses in foresight, in gleams of reason and in art capable of modification when circumstances require; it must in short give proof of the best of which its talents are capable. Let us follow it in its labours; let us interpose the experimental test; and we shall learn some curious facts.

The cocoon and its opening are constructed simultaneously. When it has woven this or that part of the general wall, the caterpillar turns about, if need be, and with its unbroken thread proceeds to continue the palisade of converging filaments. To 


\section{Aberrations of Instinct}

this end it pokes its head to the end of the roughly-defined funnel and then withdraws it, doubling the thread as it goes. This alternation of thrusts and withdrawals results in a circle of doubled filaments, which do not adhere to one another. The shift is not a long one; when the palisade is a row the richer, the caterpillar resumes its work upon the shell, a task which it again abandons to busy itself with the funnel; and so on, over and over again, the emission of the gummy product being suspended when the threads are to be left free and copiously effected when they have to be stuck together in order to obtain a solid texture.

The exit-funnel is not, as we see, a piece of work executed continuously; the caterpillar works at it intermittently, as the general shell progresses. From the beginning to the end of its spinning-period, so long as the reservoirs of silk are not exhausted, it multiplies the tiers without neglecting the rest of the cocoon. These tiers take the form of cones enclosed one within the other and of increasingly obtuse angles, until the last to be spun are so flat as to become almost level surfaces.

If nothing happen to disturb the worker, the work is performed with a perfection 


\section{The Mason-Wasps}

that would do credit to a discerning industry capable of realizing the why and wherefore of things. Can the caterpillar be said to have any conception, however slight, of the importance of its task, of the future function of its overlapping conical palisades? This is what we are about to learn.

I take a pair of scissors and remove the conical extremity while the spinner is working at the other end. The cocoon is now wide open. The caterpillar soon turns about. It thrusts its head into the wide breach which I have just made; it seems to be exploring the outside and enquiring into the accident that has occurred. I expect to see it repair the disaster and entirely reconstruct the cone destroyed by my scissors. It does, in fact, work at it for a time; it erects a row of converging threads; then, without paying further heed to the disaster, it applies its spinnerets elsewhere and continues to thicken the cocoon.

Grave doubts come to my mind: the cone built upon the breach consists of sparse filaments; it is, moreover, very flat and does not project anything like so much as the original cone. What I took at first to be a work of repair is merely a work of con- 


\section{Aberrations of Instinct}

tinuation. The caterpillar, put to the test by my tricks, has not modified the course of its work; despite the imminence of the danger, it has confined itself to the tier of threads which it would have fitted inside the preceding tier but for the snip of my scissors.

I let things go on for a while; and, when the mouth has once again acquired a certain solidity, I cut it off for the second time. The insect displays the same lack of perspicacity as before, replacing the absent cone by one with an even more obtuse angle, that is to say, continuing its usual task, without any attempt at a thorough restoration, despite the extreme urgency. If the store of silk were nearly at an end, I should sympathize with the troubles of the sorely-tried caterpillar doing its best to repair its house with the scanty materials that remain at its disposal; but I see it foolishly squandering its product on the additional upholstering of a shell which may be strong enough as it is, while economizing to the point of stinginess in the matter of the fence, which, if neglected, will leave the cell and its inhabitant at the mercy of the first thief that comes along. There is no lack of silk: the spinner applies layer upon layer to the 


\section{The Mason-Wasps}

points that are unhurt; but at the breach it employs only the quantity required under ordinary conditions. This is not economy imposed by shortage; it is blind clinging to custom. And so my commiseration changes to amazement in the presence of such profound stupidity, which applies itself to the superfluous work of upholstery in a dwelling henceforth uninhabitable, instead of attending, while there is yet time, to the business of repairing the ruins.

I make my cut a third time. When the moment has come to resume the series of boxed cones, the caterpillar arms the breach with bristles arranged in a disk, as they appear in the last courses of the undisturbed structure. This configuration shows that the end of the task is at hand. The cocoon is strengthened for a little longer; then rest ensues and the metamorphosis begins in a dwelling with a niggardly fence to it, one which would not strike terror into the puniest invader.

To sum up, the caterpillar, incapable of perceiving the dangers attendant upon an incomplete palisade, resumes its work, after each amputation of the cocoon, at the point where it had left it before the accident. Instead of thoroughly restoring the ruined 


\section{Aberrations of Instinct}

exit, which its very abundant store of silk would allow it to do; instead of reerecting on the breach a projecting cone of many layers, to replace the one removed by my scissors, it runs up layers of threads that become gradually flatter and flatter and form a continuation and not a reconstruction of the missing layers. Moreover, this work of fence-building, the need for which would seem imperious to any reasoning creature, does not appear to preoccupy the caterpillar more than usual, for it keeps on alternating this work with that of the cocoon, which is much less urgent. Everything goes by rote, as though the serious incident of the housebreaking had not occurred. In a word, the caterpillar does not begin all over again a thing once made and then destroyed; it continues it. The early stages of the work are lacking; no matter: the sequel follows without any modification in the plans.

It would be easy for me, if my argument were not already quite clear, to give a host of similar examples showing plainly that the intelligence of the insect is absolutely deficient in rational discernment, even when the great perfection of the work would seem to allow the artisan a certain per- 


\section{The Mason-Wasps}

spicacity. We will confine ourselves for the moment to the three cases which I have mentioned. The Pelopæus goes on storing 1. Spiders for an egg that has been removed; she perseveres in making hunting-trips that are henceforth useless; she hoards victuals that are destined to nourish nothing; she multiplies her battues to fill with game a larder which is forthwith emptied by my tweezers; lastly, she closes, with every customary care, a cell that no longer contains anything whatever: she sets her seal on emptiness. She does even absurder things: she plasters the site of her vanished nest, covering an imaginary structure and putting a roof to a house which at the moment is tucked away in my pocket. In the case 2. of the Great Peacock, the caterpillar, despite the certain loss of the coming Moth, instead of beginning all over again the mouth of the Eel-pot cut down by my scissors, quietly continues its spinning, without in any way modifying the regular course of the work; and, when the time comes for making the last tiers of defensive filaments, it erects them upon the dangerous breach, but neglects to rebuild the ruined portion of the barricade. Indifferent to the indispensable, it occupies itself with the superfluous. 


\section{Aberrations of Instinct}

What are we to conclude from these facts? I would fain believe, for the sake of my insects' reputation, in some distraction on their part, in some individual giddiness which would not taint the general perspicacity; I should like to regard their aberrations merely as isolated and exceptional actions, which would not affect their judgment as a whole. Alas, a long series of glaring facts would impose silence on my attempts at rehabilitation! Any species, no matter which, when subjected to experimental tests, is guilty of similar inconsistencies in the course of its disturbed industry. Constrained by the inexorable logic of the facts, I therefore state the deductions suggested by observation as follows: the insect is neither free nor conscious in its industry, which in its case is an external function with phases regulated almost as strictly as the phases of an internal function, such as digestion. It builds, weaves, hunts, stabs and paralyses, even as it digests, even as it secretes the poison of its sting, the silk of its cocoon or the wax of its combs, always without the least understanding of the means or the end. It is ignorant of its wonderful talents just as the stomach is ignorant of its skilful chemistry. 


\section{The Mason-Wasps}

It can add nothing essential to them nor subtract anything from them, any more than it is able to increase or diminish the pulsations of its dorsal vessel.

Test it with an accident and you affect it not at all: such as it is in the undisturbed exercise of its calling, such it will remain should circumstances arise demanding some modification in the conduct of its task. Experience does not teach it; time does not awaken a glimmer in the darkness of its unconsciousness. Its art, perfect in its speciality, but inept in the face of the slightest new difficulty, is handed down immutably, as the art of the suction-pump is handed down to the babe at the breast. To expect the insect to alter the essential points of its industry is to hope that the babe will change its manner of sucking. Both equally ignorant of what they are doing, they persevere in the method prescribed for the safeguarding of the species, precisely because their ignorance forbids them to make any sort of essay or attempt.

The insect, then, lacks the aptitude for reflection, the aptitude that harks back and reverts to the antecedent, without which the consequent would lose all its value. In the phases of its industry, each action accom- 


\section{Aberrations of Instinct}

plished counts as valid by the mere fact that it has been accomplished; the insect does not go back to it, should some accident demand; the consequent follows without troubling about the missing antecedent. A blind impulse urges it from one act to a second, from this second to a third and so on until the task is completed; but it is impossible for the insect to reascend the current of its activity should accidental conditions arise and call for this, however imperatively. Having passed through the complete cycle, the work is considered to be most logically performed by a worker devoid of all logic.

The stimulus to labour is the bait of pleasure, that chief motive-power in the animal. The mother has no foreknowledge whatever of her future larva; she does not build, does not hunt, does not hoard with the conscious aim of rearing a family. The real object of her work is hidden from her; the accessory but exciting aim, the pleasure experienced, is her only guide. The Peloprus feels a keen satisfaction when she crams a cell full with Spiders; and she goes on hunting with imperturbable spirit after the removal of the egg from the cell has made provisions useless. She delights in 


\section{The Mason-Wasps}

plastering the outside of her nest with mud and she continues to putty the site of her nest, after it has been detached from the wall, without suspecting the futility of her stucco. And so with the others. To reproach them for their aberrations we must assume that they possess a tiny glimmer of reason, as Darwin ${ }^{1}$ would have us believe; if they have it not, the reproach falls to the ground and their aberrant acts are the inevitable result of an unconsciousness diverted from its normal paths.

1 Charles Robert Darwin (1809-1882), the author of The Origin of Species, had the highest opinion of Fabre and spoke of him as "that incomparable observer." Fabre, on the other hand, had no faith whatever in Darwinism, nor was he greatly struck by the views and the suggestions for experiments with which Darwin favoured him from time to time. Cf. The Mason-bees: chaps. iv. and v.-Translator's Note. 


\section{CHAPTER VI}

THE SWALLOW AND THE SPARROW

7 HE Pelopæus sets us a second problem.

1 She frequents our homes, seeks the warmth of our fireplaces. A nest like hers, built of soft mud, which lets in the water, which would be dismantled by a shower and utterly destroyed by prolonged damp, must have a dry shelter; and this can be nowhere better found than in our dwelling-houses. Her susceptibility to cold makes warmth a necessity. Perhaps she is a foreigner not yet fully acclimatized, an emigrant from the shores of Africa, who, after coming from the land of dates to the land of olives, finds the sunshine in the latter insufficient and substitutes for the climate beloved of her race the artificial climate of the fireside. This would explain her habits, so unlike those of the other Wasps, all of whom shun the too-close proximity of man.

But through what stages did she pass before becoming our guest? Where did she lodge before quarters built by human industry existed, where did she shelter her 


\section{The Mason-Wasps}

brood of grubs before chimneys were thought of? When, on the hills near by, abounding in traces of their sojourn, the aborigines of Sérignan were hewing weapons out of flint, scraping Goat-skins into raiment and building huts of mud and branches, did the Pelopæus already frequent their cabins? Did she build in some bulging pot, shaped with the thumb out of half-baked black clay, and by this choice teach her latter-day descendants to seek out the peasant's gourd on the chimneypiece? Did she think of building in the folds of the garments, the spoils of the Wolf and the Bear, hanging from some set of antlers, the hat-rack of the period, thus trying her hand at a kind of annexation that was to take her at a later date to window-curtains and the labourer's smock? Did she prefer to fix her nest on the rough wall of branches and clay, near the conical orifice which let out the smoke from the primitive fire laid between four stones in the centre of the hut? Though not equal to our present chimneys, it will have served at a pinch.

What progress she has made, this Pelopxus, what a contrast between that miserable beginning and her modern premises, if she is really, in my district, a con- 


\section{The Swallow and the Sparrow}

temporary of the aborigines! She too must have profited greatly by civilization: she has managed to turn man's increasing comfort into her own. When the dwelling with a roof, rafters and ceiling was planned and the chimney with side-walls and a flue invented, the chilly creature said to herself:

"How pleasant this is! Let us pitch our tent here."

And, notwithstanding the novelty of her surroundings, she hastened to take possession.

Let us go back farther still. Before huts existed, before the niche in the rock, before man himself, the last to make his entrance on the world's stage, where did the Pelopæus build? The question is not devoid of interest, as we shall shortly see. Besides, it does not stand alone. Where did the Window-swallow and the Chimney-swallow make their nests before there were windows and chimneys to build in? What retreat did the Sparrow select for his family before there were roofs with tiles and walls with holes to them?

"As a sparrow all alone on the housetop," said the Psalmist in his day.

In King David's time, the Sparrow squawked mournfully under the eaves in the 


\section{The Mason-Wasps}

summer heat, as he does to this day. The buildings of that period differed but little from ours, at least so far as the Sparrow's convenience was concerned; and the shelter under the tile had been adopted long before. But, when Palestine had nothing more than the camel-hair tent, where did the Sparrow then elect to make his home?

When Virgil sings to us of good Evander, who, preceded by his watch, two Sheep-dogs, visits Æneas, his guest, he shows him to us awakened at dawn by the singing of the birds:

Evandrum ex humili tecto lux alma

Et matutini volucrum sub culmine cantus. ${ }^{1}$

What could those birds be which, at break of day, twittered under the roof of the old King of Latium? I see only two: the Swallow and the Sparrow, both of them chanticleers of my hermitage and as punctual as in the Saturnian days. There was nothing princely about Evander's palace. The poet does not conceal the fact, it was a lowly roof: humili tecto, he says. Besides, the furniture enlightens us as to the

1 " The cheerful morn salutes Evander's eyes; And songs of chirping birds invite to rise. He leaves his lowly bed."

Eneid: book viii; Dryden's translation. 


\section{The Swallow and the Sparrow}

edifice. The illustrious guest is given a Bear-skin and a heap of leaves for a bed:

...... stratisque locavit

Effultum foliis et pelle Libystidis ursa. ${ }^{1}$

Evander's Louvre therefore was a cabin a little larger than the others, made perhaps of tree-trunks laid one on top of the other, perhaps of unhewn stone employed as found, perhaps of reeds and clay. This rustic palace would have a thatched roof, of course. However primitive the habitation was, the Swallow and Sparrow were there, at least the poet says so. But where did they stay before they found a lodging in man's abode?

The industry of the Sparrow, the Swallow, the Pelopæus and many others cannot be subordinate to mankind's: each of them must possess a primordial art of building, one which makes the best use of the site within reach. If better conditions present themselves, they profit thereby; if these conditions are lacking, they go back to their ancient customs, whose practice, though

1 "Then underneath a lowly roof he led

The weary prince and laid him on a bed;

The stuffing leaves with hides of bears o'erspread."

Eneid: book viii ; Dryden's translation. 


\section{The Mason-Wasps}

sometimes exacting more labour, is at least always possible.

The Sparrow shali tell us first how his nest-building art stood in the days when there were no lodgings in walls and roofs. A hollow in a tree, high enough to shelter him from prying eyes, with a narrow mouth to keep out the rain and a fairly generous cavity, gives him an excellent dwelling, of which he readily avails himself even when there are plenty of old walls and roofs in the neighbourhood. The youngest bird'snester in my village knows all about it and abuses his knowledge. The hollow tree then is one lodging which the Sparrow employed, long before using Evander's cabin and David's stronghold on the rock of Zion.

His architectural resources go even further. His shapeless mattress, an incoherent jumble of feathers, down, flock, straw and other incongruous materials, seems to demand a broad and stable support. The Sparrow laughs at the difficulty and, from time to time, for reasons that remain hidden from me, he conceives a bold plan: he decides to build a nest having no support but that of three or four tiny branches at the top of a tree. The clumsy maker of 


\section{The Swallow and the Sparrow}

mattresses tries to obtain aerial suspension, a swinging house, the prerogative of weavers and basket-makers well-versed in the art of plaiting. And he succeeds.

In the fork of a few branches he accumulates everything suitable for his work that he can pick up near a house: rags, scraps of paper, ends of thread, flocks of wool, bits of hay and straw, dry blades of grass, flax dropped from the distaff, strips of bark retted by lying long in the open; and of his various gleanings, clumsily matted together, he contrives to make a large, hollow ball with a narrow opening in the side. It is bulky to a degree, the thickness of the dome having to be as good a defence against the rain as the shelter of a tile would be; it is very roughly constructed, without any attempt at artistry; but, when all is said, it is stout enough to last for a season. This is how the Sparrow must have worked in the beginning, when there was no hollow.tree at hand. Nowadays, that primitive art, too costly in time and materials, is seldom practised.

My house is shaded by two great planetrees; their branches reach the roof, on which generations of Sparrows, too many for the welfare of my cherries and my peas, 


\section{The Mason-Wasps}

succeed one another throughout the warm weather. This vast mass of greenery is the first stopping-place after the exodus from the nest begins. Here the young birds assemble and for hours chatter and scream before flying off on their pilferingexpeditions; here the well-filled squads take their stand on returning from the fields. The adults meet here to keep an eye on their recently-emancipated offspring, to caution the imprudent and encourage the timid; family-quarrels are fought out here and the events of the day discussed. From morning till evening there is a continual going to and fro between the roof and the planetrees. Well, in spite of these constant visits, I have only once, in the past twelve years, seen the Sparrow build his nest in the branches. The couple that decided in favour of a mid-air nest on one of the plane-trees were not particularly satisfied, it seems, with the results obtained, for they did not repeat the experiment next year. Since then, none has placed before my eyes for the second time a big ball of a nest swaying in the wind at the end of a branch. The steadier and less costly shelter of the tile is preferred.

We now know enough about the early art 


\section{The Swallow and the Sparrow}

of the Sparrow. What will the Swallows tell us in their turn? Two species frequent our dwellings: the Window-swallow (Hirundo urbica) ${ }^{1}$ and the Chimney-swallow (H. rustica), both of whom are very badly named, both in the scientific and the everyday language. Those epithets of urbica and rustica, which make a towndweller of the first and a villager of the second, can be applied indifferently to either, since they both take up their abode at one time in the town, at another in the village. The terms window and chimney possess a precise meaning which is rarely confirmed and very often contradicted by the facts. For the sake of clearness, the supreme condition of all tolerable prose, and to confine myself to the habits peculiar to the two species in my part of the world, I will call the first the Wall-swallow and the second the Domestic Swallow. The shape of the nest constitutes the most striking difference. The Wall-swallow gives his the form of a ball, with a round aperture just large enough to admit the bird. The Domestic Swallow fashions his into a cup with a wide opening.

1 Also known as the House-swallow, or House-martin.Translator's Note. 


\section{The Mason-Wasps}

The Wall-swallow, who is much less common than the other, never chooses a site within our houses for his structure. It must be outside for him and it must stand high, far removed from inquisitive eyes; but at the same time a shelter against the rain is indispensable, for the damp is almost as dangerous for his mud nest as for that of the Pelopæus. He therefore settles by choice under the eaves and cornices of buildings. He visits me every spring. My house pleases him. Just below the roof is a cornice made up of a few courses of ordinary "half-round" coping-tiles; corbelled out from the face of the wall in such a way as to give a long line of round-headed niches which are sheltered from the rain and enjoy plenty of sunshine on the south front. Among all these nooks, so healthy, so well-protected and moreover so excellently adapted to the shape of the nest, the bird has only to choose. There is room for all, however numerous the colony may become one day.

Apart from sites of this kind, I see none approved by the Swallow in the village, except the under part of a few cornices of the church, which is the only edifice of a monumental character. In short, the support of 


\section{The Swallow and the Sparrow}

a wall, in the open air, with some shelter against the rain, is all that the Swallow asks of our buildings.

But the natural wall is a perpendicular rock. If the bird here finds overhanging projections, forming a penthouse, it must adopt them as the equivalent of the ledge of our roofs. Ornithologists know, in fact, that in mountainous districts, far removed from human dwellings, the Wall-swallow builds against the vertical sides of the rocks, so long as his ball of clay is under cover of some kind.

Near where I live are the Gigondas Mountains, the most curious geological structure that I have ever seen. Their long chain displays so steep a slope that it is almost impossible to stand upright near the summit; and the ascent of the accessible part has to be made on all-fours. You then find yourself at the foot of a perpendicular cliff, an enormous slab of sheer rock which, like some Titanic rampart, tops the precipitous ridge with a jagged crest. The people of the country call this Cyclopean wall les Dentelles. I was one day botanizing at its base, when my eyes were attracted by the evolutions of a flock of birds in front of the rugged face of the rock. I 


\section{The Mason-Wasps}

easily recognized the Wall-swallow: his silent flight, his white belly and his ballshaped nest fastened to the cliff told me all about him. I in my turn now learnt, apart from the books, that this species fixes its nests to perpendicular rocks when the cornices of our buildings and the ledges of our roofs are missing. Even so must it have nested in the ages that preceded our stone structures.

The problem becomes thornier with the second species. The Domestic Swallow, who has much more confidence in our hospitality and is also perhaps more susceptible to cold, establishes himself as often as possible inside our houses. The embrasure of a window, the under surface of a balcony will satisfy his requirements at need; but he prefers the shed, the loft, the stable or an empty room. His familiarity even reaches the point of cohabitation with man in the same apartment. No more timid than the Pelopæus in taking possession of the premises, he installs himself in the farmkitchen and builds upon the peasant's smoke-blacked rafters; more venturesome even than the pot-making insect, he appropriates the drawing-room, the study, the bedroom or any well-kept chamber 


\section{The Swallow and the Sparrow}

that leaves him at liberty to come and go.

Each spring I have to defend myself against his bold usurpations. I gladly surrender to him the shed, the cellar-porch, the Dog's corner, the woodshed and other outhouses. This does not suffice for his ambitious views: he wants my study. At one time he tries to make his home on the curtain-rod, at another on the lintel of the open window. In vain I strive to make him understand, by destroying the foundations of his edifice as he lays them, how dangerous to his nest is the shifting support of a casement, which must be closed from time to time, at the risk of crushing house and brood alike, and how disagreeable for my curtains this dirty business is, with its mud and, later, the excretions of the young birds: I do not succeed in convincing him; and to put an end to his determined enterprise I am compelled to keep the windows shut. If I open them too soon, he returns with his beakful of clay and begins all over again.

Instructed by experience, I know what it would cost me to grant the hospitality demanded so persistently. If I were to leave some precious book open on the table, some drawing of a mushroom, my morning's 


\section{The Mason-Wasps}

work and still quite fresh from the brush, ${ }^{1}$ he would not fail, in passing, to drop his muddy seal or his stercoral initials upon it. These little annoyances have made me suspicious; and I remain obdurate to all my visitor's importunities.

Once only I allowed myself to be beguiled. The nest was placed in a corner of the ceiling and the wall, on some plaster mouldings. Below it stood a marble console-table, usually covered with books which I had to be constantly consulting. In anticipation of events, I moved my referencelibrary away. All went well until the eggs were hatched; but, as soon as the young birds were there, things changed. With their insatiable stomachs, into which the food had barely passed before it was digested and dissolved, the six fledgelings became unendurable. Every minute - flick, flack ! - it rained guano on the console. If my poor books had been there, oh dear, oh dear!

Dust and sweep as I might, my study continued redolent of ammonia. And then what a slave the birds made of me! The room was shut up at night. The father slept

1 Cf. The Life of the Fly: chap. xvii., in which the author describes his collection of water-colour drawings of mushrooms done by his own hand.-Translator's Note. 


\section{The Swallow and the Sparrow}

out; so did the mother, after the little ones were beginning to grow up. Then, at early dawn, both were at the windows, in a mighty state of distress outside the glass barrier. With eyes still heavy with sleep, I had to get up hurriedly and let the poor things in. No, I shall not allow myself to be persuaded again; never more shall I permit the Swallow to settle in a room that has to be closed at night and still less in the room where I am describing the misadventures that befel me owing to my too-accommodating kindness.

As you see, the Swallow with the nest shaped like a half-cup well deserves his epithet of domestic, inasmuch as he makes his home inside our houses. In this respect, he is among birds what the Pelopæus is among insects. Here we have once again the question of the Sparrow and the Wallswallow: where did he live before houses existed? Personally, I have never seen him build his nest elsewhere than in the shelter of our habitations; and the authors whom I consult do not appear to be any wiser on this subject. None of them says a word of the manor occupied by the bird apart from the refuges provided by human industry. Can it be that his long frequentation of our society and the consequent sense 


\section{The Mason-Wasps}

of comfort have made him forget the primitive customs of his race?

I find it difficult to believe: animals are not, to that extent, unmindful of their ancient habits, when it is necessary to remember them. Somewhere, in our day, the Swallow still works independently of us and of our buildings, even as he did in the beginning. Though observation can tell us nothing concerning the site selected, analogy makes up for this silence with a wealth of probabilities. After all, what do our houses represent to the Domestic Swallow? Refuges against the weather, especially against the rain, which does so much harm to the mud shell. Natural grottoes, caves, the irregularities of crumbling rocks: these are all refuges, less healthy, perhaps, but still well worth having. It was here, beyond a doubt, that the Swallow constructed his nest when he had no human dwellings to build in. Man contemporary with the Mammoth and the Reindeer came and shared his lodging under the rock. Intimacy sprang up between the two. Then, step by step, the cave was succeeded by the hut, the hut by the cabin, the cabin by the house; and the bird, abandoning the less good for the better, followed man into his improved abode. 


\section{The Swallow and the Sparrow}

We will now end this digression on the habits of birds and apply the evidence which we have gathered to the Pelopæus. Every species practising its industry in our dwellings must first have practised and, we maintain, must still practise it under conditions wholly extraneous to the work of man. The Wall-swallow and the Sparrow have given us proofs which are all that can be desired; the Domestic Swallow, more reticent of his secrets, gave us only probabilities, which however come very near to certainty. The Pelopæus is almost as obstinate as the last-named in refusing to divulge her ancient customs and long remained to me an insoluble problem in so far as her original domicile was concerned. Where can the enthusiastic colonist of our chimneys have lived, when far removed from man? Thirty years and more elapsed after I first made her acquaintance; and her history always ended in a note of interrogation. Outside our houses, never a trace of a Pelopæus-nest. And all the time I was applying the method of analogy, which provides a very probable answer to the question of the Domestic Swallow; I was pursuing my search in the caves, in the shelters under rocks facing the sun. Not a sign. I was 


\section{The Mason-Wasps}

still continuing my useless investigations, when at last chance, which favours the persevering, thrice compensated me, under conditions which I did not for a moment suspect of being auspicious.

The Sérignan quarries are rich in accumulations of broken stones, refuse that has lain piled up there for centuries. These stone-heaps are the refuge of the Fieldmouse, who, on a mattress of dried grass, crunches the almonds, olive-stones and acorns which he picks up all around and varies this farinaceous diet with Snails, whose empty shells lie packed under some flat stone. Different Bees and Wasps Osmix, Anthidia, Odyneri-pick out shells to suit them from the heap and build their cells in the spiral. My search for these treasures makes me turn over a few cubic yards of broken stones every year.

Three times, when engaged upon this task, I came upon the Pelopæus' work. Two nests were placed deep down in the heap, against blocks hardly bigger than a man's two fists; the third was fixed to the lower surface of a large flat stone, forming a canopy above the ground. These three nests, though subject to all the changes of the weather, contained nothing more than 


\section{The Swallow and the Sparrow}

the usual structure found inside our houses. The material was plastic mud, as always; the protection, a covering of the same mud; and that was all. The dangers of the site had suggested no improvement to the architect; the edifice was no different from those built against the wall of a chimney. One point is established, therefore: in my district, the Pelopæus nidifies sometimes, but very rarely, in stone-heaps and under natural flagstones which do not touch the ground. Thus must she have nidified before becoming the inmate of our dwellings and our fireplaces.

A second point is open to discussion. The three nests found under the stones are in a piteous state. Soaked with damp, they possess hardly more consistency than the muddy puddle utilized for their construction. They are softened to such a degree that they can no longer be handled. The cells are ripped open; the cocoons, easily recognizable by their colour and their transparency, which is that of an onion-skin, are in pieces, without any vestige of the larvæ which I ought to find at the time of my discovery, that is in winter. And yet the three hovels are not old nests ruined by the weather after the emergence of the 


\section{The Mason-Wasps}

perfect insect, for the exit-doors are still closed with their well-fitting plugs. It is at an abnormal place, in the side, that the yawning breach occurs. The escaping insect would never use such violence in breaking through. They are certainly recent nests, nests of the previous summer.

Their dilapidation is due to their unprotected position. The rain penetrates into the stone-heaps; even under the shelter of a flagstone the air is saturated with damp. If a little snow falls, the mischief is still worse. In this way, the wretched nests crumble and fall to pieces, leaving the cocoons partly exposed. Unprotected by their earthen sheath, the larva have become the prey of the brigandage that mows down the weak. Some Field-mouse passing by has perhaps feasted on those tender morsels.

At the sight of these ruins a suspicion occurs to me. Is the primitive art of the Pelopæus really practicable in my region? When nesting in stone-heaps, does the tiny potter find the security needed for her family, especially during the winter? It is very doubtful. The extreme rarity of the nests in such conditions is evidence of the mother's aversion for these sites; and the 


\section{The Swallow and the Sparrow}

dilapidated state of those which I find seems to testify to their dangerous nature. If the inclemency of the climate makes it impossible for the Pelopæus to practise the industry of her forebears successfully, does not this prove that the insect is a stranger, a colonist from a hotter and drier climate, where there is no persistent rain and above all no snow to be dreaded?

I have no difficulty in picturing the $\mathrm{Pe}$ lopæus as of African origin. Far back in the past she came to us, by gradual stages, through Spain and Italy; and the olive-district is almost the limit of her extension towards the north. She is an African who has become a Provençal by naturalization. In Africa, in fact, she is said often to nest under the stones, which would not, I think, make her despise human habitations, if she found peace and quiet there. We hear of her kinswomen in the Malay Archipelago frequenting houses. They have the same habits as the guest of our homes; they share her singular liking for that unstable fabric, a muslin curtain. From one end of the world to the other, the same taste for Spiders, for mud cells, for sheltering under man's roof. If I were in the Malay Archipelago, I should turn over the stone- 


\section{The Mason'-Wasps}

heaps and should most likely discover one further resemblance: the original nest under some flat stone. 


\section{CHAPTER VII}

\section{INSTINCT AND DISCERNMENT}

THE Pelopæus gives us a very poor idea of her intellect when she plasters the spot in the wall where the nest which I have removed used to stand, when she persists in cramming her cell with Spiders for the benefit of an egg no longer there and when she dutifully closes a cell which my tweezers, extracting both germ and provisions, have left empty. The Mason-bees, the caterpillar of the Great Peacock Moth and many others, when subjected to similar tests, are guilty of the same illogical behaviour: they continue, in the normal order, their series of industrious actions, though an accident has now rendered these useless. Just like mill-stones, which do not cease revolving though there be no corn left to grind, let them once be given the compelling power and they will continue to perform their task despite its futility. Are they then machines? Far be it from me to think anything so foolish.

It is impossible to make definite progress 


\section{The Mason-Wasps}

on the shifting sands of contradictory facts: each step in our interpretation may find us embogged. And yet these facts speak so loudly that I do not hesitate to translate their evidence as I understand it. In insect mentality, we have to distinguish two very different domains. One of these is instinct properly so called, the unconscious impulse that presides over the most wonderful part of what the creature achieves with its industry. Where experience and imitation are of absolutely no avail, instinct lays down its inflexible law. It is instinct and instinct alone that makes the mother build for a family which she will never see; that counsels the storing of provisions for the unknown offspring; that directs the sting towards the nerve-centres of the prey and skilfully paralyses it, so that the game may keep good; that instigates, in fine, a host of actions wherein shrewd reason and consummate science would have their part, were the creature acting through discernment.

This faculty is perfect of its kind from the outset; otherwise the insect would have no posterity. Time adds nothing to it and takes nothing from it. Such as it was for a definite species, such it is to-day and such it will remain, perhaps the most settled zoo- 


\section{Instinct and Discernment}

logical characteristic of them all. It is not free nor conscious in its practice, any more than is the faculty of the stomach for digestion or that of the heart for pulsation. The phases of its operations are predetermined, necessarily entailed one by another; they suggest a system of clockwork wherein one wheel set in motion brings about the movement of the next. This is the mechanical side of the insect, the fatum, the only thing that is able to explain the monstrous illogicality of a Pelopæus misled by my artifices. Is the Lamb when it first grips the teat a free and conscious agent, capable of improvement in its difficult art of taking nourishment? The insect is no more capable of improvement in its art, more difficult still, of giving nourishment.

But, with its hide-bound science ignorant of itself, pure instinct, if it stood alone, would leave the insect unarmed in the perpetual conflict of circumstances. No two moments in time are identical; though the background remain the same, the details change; the unexpected rises on every side. In this bewildering confusion, a guide is needed to seek, accept, refuse and select; to show preference for this and indifference to that; to turn to account, in short, anything 


\section{The Mason-Wasps}

useful that occasion may offer. This guide the insect undoubtedly possesses, to a very manifest degree. It is the second province of its mentality. Here it is conscious and capable of improvement by experience. I dare not speak of this rudimentary faculty as intelligence, which is too exalted a title: I will call it discernment. The insect, in exercising its highest gifts, discerns, differentiates between one thing and another, within the sphere of its craft, of course; and that is about all.

So long as we confound acts of pure instinct and acts of discernment under the same head, we shall fall back into those endless discussions which embitter controversy without bringing us one step nearer to the solution of the problem. Is the insect conscious of what it does? Yes and no. No, if its action falls within the domain of instinct; yes, if the action falls within that of discernment. Are the habits of an insect capable of modification? No, decidedly not, if the habit in question belongs to the province of instinct; yes, if it belongs to that of discernment. Let us state this fundamental distinction mere precisely with the aid of a few examples.

The Pelopæus builds her cells with earth I 58 


\section{Instinct and Discernment}

already softened, with mud. Here we have instinct, the unalterable characteristic of the worker. She has always built in this way and always will. The passing ages will never teach her, neither the struggle for life nor the law of selection will ever induce her to imitate the Mason-bee and collect dry dust for her mortar. This mud nest of hers needs a shelter against the rain. The hiding-place under a stone suffices at first. But should she find something better, the potter takes possession of that something better and instals herself in the home of man. There we have discernment, the source of some sort of capacity for improvement.

The Pelopæus supplies her larvæ with provisions in the form of Spiders. There you have instinct. The climate, the latitude or longitude, the changing seasons, the abundance or scarcity of game introduce no modification into this diet, though the larva shows itself satisfied with other fare provided by myself. Its forebears were brought up on Spiders; their descendants consumed similar food; and their posterity again will know no other. Not a single circumstance, however favourable, will ever persuade the Pelopæus that young Crickets, 


\section{The Mason-Wasps}

for instance, are as good as Spiders and that her family would accept them gladly. Instinct binds her down to the national diet.

But, should the Epeira, the favourite prey, be lacking, must the Pelopæus give up foraging? She will stock her warehouses all the same, because any Spider suits her. There you have discernment, whose elasticity makes up, in certain circumstances, for the excessive rigidity of instinct. Amid the innumerable variety of game, the huntress is able to discern between what is Spider and what is not; and in this way she is always prepared to supply her family, without quitting the domain of her instinct.

The Hairy Ammophila gives her larva a single caterpillar, a large one, paralysed by as many pricks of her sting as it has nervous centres in its thorax and abdomen. Her surgical skill in subduing the monster is instinct, displayed in a form that quashes any inclination to see in it an acquired habit. In an art that can leave no one to practise it in the future unless that one be perfect at the outset, of what avail are lucky chances, atavistic tendencies, or the mellowing hand of time? But the grey caterpillar, sacrificed one day, may be succeeded on another day by a green, yellow or striped caterpillar. 


\section{Instinct and Discernment}

There you have discernment, which is quite capable of recognizing the regulation prey under very diverse garbs.

The Megachiles " build their honey-jars with disks cut out of leaves; certain Anthidia make felted cotton wallets; others fashion pots out of resin. There you have instinct. Will any rash mind ever conceive the singular idea that the Leaf-cutter might very well have started working in cotton, that the cotton-wool-worker once thought or will one day think of cutting disks out of the leaves of the lilac- or the rose-tree, that the resin-kneader began with clay? Who would dare to indulge in such theories? Each Bee has her art, her medium, to which she strictly confines herself. The first has her leaves; the second her wadding; the third her resin. None of these guilds has ever changed trades with another; and none ever will. There you have instinct, keeping the workers to their specialities. There are no innovations in their workshops, no formulæ resulting from experiment, no ingenious devices, no progress from the indifferent to the good, from the good to the excellent. To-day's method

1 Or Leaf-cutters. Cf. Bramble-bees and Others: chap. viii.-Translator's Note. 


\section{The Mason-Wasps}

is the facsimile of yesterday's; and to-morrow will know no other.

But, though the manufacturing-process is invariable, the raw material is subject to change. The plant that supplies the cotton differs in species according to the locality; the bush out of whose leaves the pieces will be cut is not the same in the various fields of operation; the tree that provides the resinous putty may be a pine, a cypress, a juniper, a cedar or a spruce, all very different in appearance. What will guide the insect in its gleaning? Discernment.

These, I think, are sufficient details of the fundamental distinction to be drawn in the insect's mentality, the distinction, that is, between pure instinct and discernment. If people confuse these two provinces, as they nearly always do, any understanding becomes impossible; the last glimmer of light disappears behind the clouds of interminable discussions. From an industrial point of view, let us look upon the insect as a worker thoroughly versed from birth in a craft whose essential principles never vary; let us grant that unconscious worker a gleam of intelligence which will permit it to extricate itself from the inevitable conflict of attendant circumstances; and I think 


\section{Instinct and Discernment}

that we shall have come as near to the truth as the state of our knowledge will allow for the moment.

Having thus assigned a due share both to instinct and to its aberrations when the course of its different phases is disturbed, let us see what discernment is able to do in the selection of a site for the nest and materials for building it; and, leaving the Pelopæus, upon whom it is useles to dwell any longer, let us consider other examples, picked from among those richest in variations.

The Mason-bee of the Sheds (Chalicodoma rufitarsis, PÉREZ) well deserves the name which $I$ have felt justified in giving her from her habits: she settles in numerous colonies in our sheds, on the lower surface of the tiles, where she builds huge nests which endanger the solidity of the roof. Nowhere does the insect display a greater zeal for work than in one of these colossal cities, an estate which is constantly increasing as it passes down from one generation to another; nowhere does it find a better workshop for the exercise of its industry. Here it has plenty of room, a quiet restingplace, sheltered from damp and from excess of heat or cold. 


\section{The Mason-Wasps}

But the spacious domain under the tiles is not within the reach of all: sheds with free access and the proper sunny aspect are pretty rare. These sites fall only to fortune's favourites. Where will the others take up their quarters? More or less anywhere. Without leaving the house in which I live, I can enumerate stone, wood, glass, metal, paint and mortar as forming the foundation of the nests. The greenhouse with its furnace heat in the summer and its bright light, equalling that outside, is fairly well-frequented. The Mason-bee hardly ever fails to build there each year, in squads of a few dozen, now on the glass panes, now on the iron bars of the framework. Other little swarms settle in the window-embrasures, under the projecting ledge of the front-door or in the cranny between the wall and an open shutter. Yet others, being perhaps of a morose disposition, flee society and prefer to work in solitude, one in the inside of a lock or of a pipe intended to carry the rain-water from the leads; another in the mouldings of the doors and windows or in the crude ornamentation of the stonework. In short, the house is made use of all round, provided that the shelter be an out-of-door one; for 


\section{Instinct and Discernment}

observe that the enterprising invader, unlike the Pelopæus, never penetrates inside our dwellings. The case of the conservatory is an exception more apparent than real: the glass building, standing wide open throughout the summer, is to the Masonbee but a shed a little lighter than another. There is nothing here to arouse the distrust with which anything indoors or closed inspires her. To build on the threshold of an outer door, to usurp its lock, a hidingplace to her fancy, is all that she allows herself; to go any farther is an adventure repugnant to her taste.

Lastly, in the case of all these dwellings, the Mason-bee is man's free tenant; her industry makes use of the products of our own industry. Can she have no other establishments? She has, beyond a doubt; she possesses some constructed on the ancient plan. On a stone the size of a man's fist, protected by the shelter of a hedge, sometimes even on a pebble in the open air, I see her building now groups of cells as large as a walnut, now domes emulating in size, shape and solidity those of her rival, the Masonbee of the Walls.

The stone support is the most frequent, though not the only one. I have found 


\section{The Mason-Wasps}

nests, but sparsely inhabited it is true, on the trunks of trees, in the seams of the rough bark of oaks. Among those whose support was a living plant, I will mention two that stand out above all the others. The first was built in the grooves of a $\mathrm{Pe}$ ruvian torch-thistle as thick as my leg; the second rested on a stalk of the opuntia, the Indian fig. Had the fierce armour of these two stout cactuses attracted the attention of the insect, which looked upon their tufts of spikes as furnishing a system of defence for its nest? Perhaps so. In any case, the attempt was not imitated; I never saw another installation of the kind. There is one definite conclusion to be drawn from my two discoveries. Despite the oddity of their structure, which is unparalleled in the local flora, the two American importations did not compel the insect to go through an apprenticeship of groping and hesitation. The one which found itself in the presence of those novel growths and which was perhaps the first of its race to do so took possession of their grooves and stalks just as it would have done of a familiar site. From the start, the fleshy plants from the New World suited it quite as well as the trunk of a native tree. 


\section{Instinct and Discernment}

The Mason-bee of the Pebbles (Chalicodoma parietina) has none of this elasticity in the choice of a site. In her case, the smooth stone of the parched uplands is the almost invariable foundation of her structures. Elsewhere, under a less clement sky, she prefers the support of a wall, which protects the nest against the prolonged snows. Lastly, the Mason-bee of the Shrubs (C. rufescens, PÉrez) fixes her ball of clay to a twig of any ligneous plant, from the thyme, the rock-rose and the heath to the oak, the elm and the pine. The list of the sites that suit her would almost form a complete catalogue of the ligneous flora.

The variety of places where the insect installs itself, so eloquent of the part played by discernment in their selection, becomes still more remarkable when accompanied by a corresponding variety in the architecture of the cells. This is more particularly the case with the Three-horned Osmia, ${ }^{1}$ who, as she uses clayey materials very easily affected by the rain, requires, like the Pelopæus, a dry shelter for her cells, a shelter which she finds ready-made and uses

1 Cf. Bramble-bees and Others: passim.-Translator's Note. 


\section{The Mason-Wasps}

just as it is, after a few touches by way of sweeping and cleansing. The homes which I see her adopt are especially the shells of Snails that have died under the stone-heaps and in the low, unmortared walls which support the cultivated earth of the hills in shelves or terraces. The use of Snailshells is accompanied by the no less active use of the old cells of both the Mason-bee of the Sheds and of certain Anthophoræ (A. pilipes, $A$. parietina and $A$. personata.) 1

We must not forget the reed, which is highly appreciated when - a rare find it appears under the desired conditions. In its natural state, the plant with the mighty hollow cylinders is of no possible use to the Osmia, who knows nothing of the art of perforating a woody wall. The gallery of an internode has to be wide open before the Bee can take possession of it. Also, the clean-cut stump must be horizontal, otherwise the rain would soften the fragile edifice of clay and soon lay it low; also, the stump must not be lying on the ground and must be kept at some distance from the dampness of the soil. We see

1 Cf. Bramble-bees and Others: passim.-Translator's Note. 


\section{Instinct and Discernment}

therefore that, without the intervention of man, involuntary in the vast majority of cases and deliberate only on the experimenter's part, the Osmia would hardly ever find a reed-stump suited to the installation of her family. It is to her a casual acquisition, a home unknown to her race before men took it into their heads to cut reeds and make them into hurdles for drying figs in the sun.

How did the work of man's pruningknife bring about the abandonment of the natural lodging? How was the spiral staircase of the Snail-shell replaced by the cylindrical gallery of the reed? Was the change from one kind of house to another effected by gradual transitions, by attempts made, abandoned, resumed, becoming more and more definite in their results as generation succeeded generation? Or did the Osmia, finding the cut reed that answered her requirements, install herself there straightway, scorning her ancient dwelling, the Snail-shell? These questions called for a reply; and they have received one. Let us describe how things happened.

Near Sérignan are some great quarries of coarse limestone, characteristic of the miocene formation of the Rhone valley. 


\section{The Mason-Wasps}

These have been worked for many generations. The ancient public buildings of Orange, notably the colossal frontage of the theatre whither all the intellectual world once flocked to hear Sophocles' Edipus Tyrannus, derive most of their material from these quarries. Other evidence confirms what the similarity of the hewn stone tells us. Among the rubbish that fills up the spaces between the tiers of seats, they occasionally discover the Marseilles obol, a bit of silver stamped with the four-spoked wheel, or a few bronze coins bearing the effigy of Augustus or Tiberius. Scattered also here and there among the monuments of antiquity are heaps of refuse, accumulations of broken stones in which various Bees and Wasps, including the Three-horned Osmia in particular, take possession of the dead Snail-shell.

The quarries form part of an extensive plateau which is so arid as to be nearly deserted. In these conditions, the Osmia, at all times faithful to her birth-place, has little or no need to emigrate from her heap of stones and leave the shell for another dwelling which she would be obliged to seek at a distance. Since there are heaps of stone there, she probably has no other 


\section{Instinct and Discernment}

dwelling than the Snail-shell. Nothing tells us that the present-day generations are not descended in the direct line from the generations contemporary with the quarryman who lost his as or his obol at this spot. All the circumstances seem to point to it: the Osmia of the quarries is an inveterate user of Snail-shells; so far as heredity is concerned, she knows nothing whatever of reeds. Well, we must place her in the presence of these new lodgings.

I collect during the winter about two dozen well-stocked Snail-shells and install them in a quiet corner of my study, as I did at the time of my enquiries into the distribution of the sexes. ${ }^{1}$ The little hive with its front pierced with forty holes has bits of reed fitted to it. At the foot of the five rows of cylinders I place the inhabited shells and with these I mix a few small stones, the better to imitate the natural conditions. I add an assortment of empty Snail-shells, after carefully cleaning the interior so as to make the Osmia's stay more pleasant. When the time comes for nestbuilding, the stay-at-home insect will have, close beside the house of its birth, a choice

1 Cf. Bramble-bees and Others: chaps. iii. and iv.Translator's Note. 


\section{The Mason-Wasps}

of two habitations: the cylinder, a novelty unknown to its race; and the spiral staircase, the ancient ancestral home.

The nests were finished at the end of May and the Osmix began to answer my interrogatory. Some of them, the great majority, settled exclusively in the reeds; the others remained faithful to the Snail-shell, or else entrusted their eggs partly to the spirals and partly to the cylinders. With the first, who were the pioneers of cylindrical architecture, there was no hesitation that I could perceive: after exploring the stump of reed for a time and recognizing it as serviceable, the insect installs itself there and, an expert from the first touch, without apprenticeship, without groping, without any tendencies bequeathed by the long practice of its predecessors, builds its straight row of cells on a very different plan from that demanded by the spiral cavity of the shell, which increases in size as it goes on.

The slow school of the ages, the gradual acquisitions of the past, the legacies of heredity count for nothing, therefore, in the Osmia's education. Without any noviciate on its own part or that of its forebears, the insect is versed straight away in the calling which it has to pursue; it possesses, in- 


\section{Instinct and Discernment}

separable from its nature, the qualities demanded by its craft: some which are invariable and belong to the province of instinct; others which are flexible and belong to the province of discernment. To divide a free lodging into chambers by means of mud partitions; to fill these chambers with a heap of pollen-flour, with a few sups of honey in the central part where the egg is to lie; in short, to prepare board and lodging for the unknown, for a family which the mothers have never seen in the past and will never see in the future: this, in its essential features, is the function of the Osmia's instinct. Here, everything is har-d moniously, inflexibly, permanently preordained; the insect has but to follow its blind impulse to attain the goal. But the free lodging offered by chance varies exceedingly in hygienic conditions, in shape and in capacity. Instinct, which does not choose, which does not contrive, would, if it were alone, leave the insect's existence in peril. To help her out of her predicament, in these complex circumstances, the Osmia possesses her little stock of discernment, which distinguishes between the dry and the wet, the solid and the fragile, the sheltered and the exposed; which recognizes the worth or 


\section{The Mason-Wasps}

worthlessness of a site and knows how to sprinkle it with cells according to the size and shape of the space at its diposal. Here, slight industrial variations are necessary and inevitable; and the insect excels in them without any apprenticeship, as the experiment with the Osmia born in the quarries has proved.

Animal resources have a certain elasticity within narrow limits. What we learn from the animals' industry at a given moment is not always the full measure of their skill. They possess latent powers held in reserve for certain emergencies. Long generations can succeed one another without employing them; but, should some circumstance require it, suddenly those powers burst forth, free of any previous attempts, even as the spark potentially contained in the flint flashes forth independently of all preceding gleams. Could one who knew nothing of the Sparrow except the nest under the eaves suspect the ball-shaped nest at the top of a tree? Would one who knew nothing of the Osmia save her home in the Snail-shell expect to see her accept as her dwelling a stump of reed, a paper funnel, a glass tube? My neighbour the Sparrow, impulsively taking it into his head to leave the roof for 


\section{Instinct and Discernment}

the plane-tree, the Osmia of the quarries, rejecting her natal cabin, the Snail-shell, for my cylinders, alike show us how sudden and spontaneous are animals' industrial variations. 


\section{CHAPTER VIII}

\section{THE NEST-BUILDING ODYNERUS}

IF further proofs than those submitted 1 elsewhere were needful, to demonstrate that the organ does not imply the function, that the implement does not determine the work, ${ }^{1}$ the Odynerus group would furnish us with very remarkable evidence. With a close similarity of organization, not only in the details but also in the aggregate, a similarity which makes these insects one of the most natural genera in respect of structure, they possess a great variety of industries, bearing no relation one to the other, though carried on with the same equipment. Apart from the likeness in form, one single characteristic unites this group, whose habits are so unlike: all the Odyneri are gamehunters; they victual their families with grubs paralysed with the sting, with little caterpillars and small Beetle-larvæ.

But to achieve this common end, the larder furnished with its egg and stuffed

1 Cf. the essay on the Resin-bees in Bramble-bees and Others: chap. x.-Translator's Note. 


\section{The Nest-building Odynerus}

with game, how many several methods of construction! If we were better-acquainted with the biology of the genus, we should perhaps find architects of almost as many different schools as there are species. My investigations, which were dependent on opportunity, have as yet borne upon only three of the Odyneri; and these three, with the same implement, the curved, toothed pincers of their mandibles, apply themselves to the most dissimilar industries.

One of them, O. reniformis, whose work I have described in an earlier chapter, digs a deep gallery in a hard soil and with the rubbish constructs, at the mouth of her well, a sort of curved chimney, with a guilloche pattern, the materials of which are afterwards again employed to close the abode. Formerly, when I made her acquaintance in front of a steep loamy bank baked by the sun, I whiled away the long hours of waiting by conversing, turn and turn about, with the Hoopoe, who taught me how to pronounce Latin, and with my Dog, who, lying in the shade of a leafy thicket, cooling his belly in the moist sand, taught me how to practise patience. The Wasp was rare and by no means prodigal of her returns to the nest where I was watching her skilful tac- 


\section{The Mason-Wasps}

tics. Nowadays, every spring, I have a populous colony of her before my eyes in one of the paths of my enclosure. When the period for the works arrives, I surround the hamlet with stakes to mark the site, lest heedless footsteps should destroy the pretty chimneys built of grains of earth.

The second, $O$. alpestris, SAUss., is by trade a resin-worker. Possessing the same tnol as her colleague the miner, but not the same skill, she does not dig herself a dwelling; she prefers to settle down in borrowed lodgings provided by an empty Snail-shell. The shells of Helix nemoralis, of $H$. aspers $a,{ }^{1}$ when very incompletely developed, and of Bulimulus radiatus are the only dwellings that I have known her to occupy and also the only ones that would serve her turn under the stone-heaps where, in company with Anthidium bellicosum, she performs her labours in July and August.

Saved by the Snail from the hard task of excavation, she specializes in mosaic and produces a work of art which is superior in elegance to the miner's temporary guilloche. Her materials are, on the one hand, resin; on the other, little bits of gravel. $\mathrm{Her}$ method is very unlike that of the two resin-

1 The Common Snail.-Translator's Note. 


\section{The Nest-building Odynerus}

workers who find a lodging in the shell of the Edible Snail. These two swamp with gum, on the outer surface of the lid, their coarse, angular bricks, which are unequal in size, variable in nature and often of a half-earthy character, so that the unevenness of the work, in which the pieces are laid side by side at random, is hidden under a coat of resin. On the inner surface the gum does not fill the gaps and the cemented fragments appear with all their irregular projections and their clumsy arrangement.

Remember also that the bits of gravel are kept exclusively for the operculum, or lid, the final covering; the partitions which mark off the cells are made entirely of resin, without any mineral particles.

The Alpine Odynerus works on a different plan: she saves pitch by making better use of stone. A number of round, flinty atoms are set in a bed of still sticky cement, on the outer surface. They fit one against the other, are almost all of the same size, that of a pin's head, and are selected singly by the artist amid the miscellaneous rubbish that litters the ground. When it is well-executed, as is frequently the case, the result suggests a piece of embroidery worked with roughly-fashioned beads of 


\section{The Mason-Wasps}

quartz. The Anthidia of the Snail-shell, rude labourers that they are, accept all that falls to their mandibles: angular splinters of limestone, morsels of flint, bits of shell, hard particles of earth; the daintier Odynerus as a rule inlays with beads of flint only. Can this taste for gems be due to the brilliancy, the translucency, the polish of the grain? Can it be that the insect takes pleasure in its casket of precious stones? The answer will be the same as in the case of the ornamental rose-window, the tiny shell sometimes inserted in the centre of the lid by the two resin-gatherers who inhabit the shell of the Edible Snail: why not?

$\mathrm{Be}$ this as it may, the gem-collector is so pleased with her pretty pebbles that she puts them everywhere. The partitions that subdivide the shell into chambers are reproductions of the lid: each has a carefullyfinished mosaic of translucent flints on the front surface. In this manner three or four cells are contrived in the shell of the Edible Snail; in that of the Bulimulus, two at most. The cells are small but correctly shaped and strongly protected.

The protection, for that matter, is not restricted to these multiple paved hangings: 


\section{The Nest-building Odynerus}

if you hold the Snail-shell to your ear and shake it, you hear a rattle of stones. The Odynerus, in fact, is as familiar as the Anthidia with the art of fortification by means of barricades. I make a breach in the side of the Snail-shell and pour out the heap of loose gravel that blocks the vestibule between the last partition and the lid. One detail should be noted: the materials which I collect are not homogeneous. Small polished pebbles predominate, but they are mixed with fragments of coarse limestone, bits of shell and particles of earth. The Odynerus, so fastidious in choosing the flint for her mosaics, employs for her filling the first rubbish that comes to hand. Even so do the two resin-gatherers act when barricading their Snail-shells. As a conscientious historian, I will add that the incoherent heap of rubbish is not always there: another point of resemblance with the practice of the Anthidia.

To my great regret, I can carry the biography of the Alpine Odynerus no farther. The insect appears to me to be very rare. I come upon its nest at long intervals in winter, the only season propitious to laborious searches in the stone-heaps. With the dwelling and its inhabitant, hatched in my 


\section{The Mason-Wasps}

specimen-jars, I am familiar; but the egg, the larva and the provisions I do not know.

In compensation, I possess all the details that could be desired about the third species, $O$. nidulator, SAuss. This insect, like the just mentioned, is ignorant of the art of laying the foundations of its abode and demands a ready-made lodging. Like the Osmix, the Megachiles and the cottonspinning Anthidia, it wants a cylindrical gallery, either natural or excavated by miners. Its art consists in partitioning a tunnel and subdividing it into chambers: plasterer's art, in short.

Here then, in three species, the only ones whose habits I have had the opportunity of learning, we see three very different trades: the miner's, the resin-worker's and the plasterer's. In these three guilds I find exactly the same equipment of tools; and I defy the most meticulous magnifying-glass to tell us what organic modification suggests to the one insect the pavement of pebbles upon a bed of resin, to the second the mine-shaft with its guilloched chimney, to the third the alien cylinder, partitioned with mud. No and again no: the organ does not constitute the function, the tool does not make the workman. With similar implements, 


\section{The Nest-building Odynerus}

the Odynerus group executes the most dissimilar tasks, because each species has its predetermined skill, its art that governs the tool and is not governed by it. How plainly this conclusion would appear had I been privileged to review the entire Odynerus genus! How many industries remain for us to see, with the tool undergoing no modification! I suggest investigations on these lines to whomsoever it may concern, were it only in order to shed a little light upon this numerous and difficult group, of which the future will, I trust, give us a lucid classification based upon its industrial guilds.

Let us leave these generalities and pass to the detailed story of the Nest-building Odynerus. There are few Wasps with whose private life I am better acquainted; and $I$ owe this abundant information to circumstances which, for me, impart a double value to the facts, because of the pleasant memories evoked. I had often extracted the Nest-building Odynerus' series of cells from the old galleries of the Anthophoræ; I knew that the insect occupies dwellings not dug with its own mandibles and that its labours are confined to the partitions; I knew its yellow larva and its slender, amber-hued 183 


\section{The Mason-Wasps}

cocoon. I knew nothing of all the rest, when I received from my daughter Claire a bundle of reed-cuttings which filled me with exultation.

Brought up in a zoological house, the dear child has retained a vivid memory of our evening talks, in which the insect so often cropped up; and her discerning eye is able quickly to distinguish, amid her casual discoveries, anything that may assist me in my studies of instinct. Her country home, in the neighbourhood of Orange, boasts a rustic poultry-house constructed partly of reeds laid in horizontal stages. In the middle of June last year (1889), she noticed, when visiting her Hens, certain Wasps making their way in large and busy numbers into the cut reeds, coming out again and soon returning laden with a load of earth or some malodorous little grub. Her attention once aroused, the rest did not take long: she had discovered a magnificent subject for me to study. That very evening I received a bundle of reeds, with a letter giving me circumstantial details.

The Wasp, as Claire called it and as Réaumur named it of old, when speaking of a species of the same genus but of very different habits, the Wasp, so the letter told 184 


\section{The Nest-building Odynerus}

me, hoards in her nests a dumpy head of game, covered with black spots and smelling strongly of bitter almonds. I informed my daughter that this game was the larva of the Poplar Leaf-beetle (Chrysomela populi), a Beetle with red wing-cases reminding one, on a larger scale, of the Coccinella, or Common Ladybird. Insect and larva should be found together on the poplars of the neighbourhood, browsing promiscuously on the leaves. I added that a glorious opportunity had presented itself and that we must profit by it without delay. She therefore received instructions to keep a watch on this, that and the other and to furnish my insect laboratory with reedstumps as and when they became colonized and with poplar-branches covered with Chrysomela-grubs. A collaboration was thus set up between Orange and Sérignan, the facts observed on both sides mutually completing and corroborating each other.

Let us come quickly to the bundle of reeds, the first examination of which gratifies my fondest hopes. It contains things that reawaken all the enthusiasm of my youth: cells converted into game-baskets, eggs on the point of hatching beside the victuals, new-born grubs biting into their first victim, 


\section{The Mason-Wasps}

larvæ of fuller growth, weavers at work on their cocoons, in fact everything that one could wish for. Never, except with the Scolix in my heap of garden-mould, ${ }^{1}$ has fortune served me better. Let us make an orderly inventory of these rich documents.

Already various Bees that favour borrowed houses have shown us the insect discriminating between one dwelling and another and selecting the best to make their homes in. We now have a predatory Wasp who, following the example of the Osmix, the Leaf-cutters and the Cottonbees, leaves the ancestral cabin for the cylinder of the reed, to which man's pruningknife has prepared the access. The natural shelter, of indifferent quality, is succeeded by the artificial and more convenient refuge. The Odynerus' primitive lodging is the abandoned corridor of the Anthophora, or any other burrow dug in the earth by no matter what miner. The wooden tube, free from damp and bathed in sunshine, is recognized as preferable; and the insect hastens to adopt it when the opportunity occurs. The tunnel of the reed must be recognized as an excellent habitation,

1 Cf. The Life and Love of the Insect: chap. xi.Translator's Note. 


\section{The Nest-building Odynerus}

superior to all others, for never outside any abode of Anthophoræ have I seen a colony of Odyneri so populous as that of the Orange poultry-house.

The reeds invaded are laid horizontally, a condition on which the Bees likewise insist, if only to shelter from the rain the housedoor, plugged with pervious materials, such as mud, cotton, or round, leafy disks. Their inner diameter attains an average of two-fifths of an inch. The length occupied by the cells varies greatly. Sometimes the Odynerus takes possession only of that fragment of the interval between two knots which the stroke of the pruning-knife has left free, a fragment longer or shorter according to the chances of the cutting. In that case, a small number of cells is enough to fill the available space. But generally, if the stump be too short and not worth the trouble of working, the insect bores through the partition at the end and thus adds a complete internode to the vestibule with the open entrance. In a lodging of this kind, some eight inches long, the number of chambers will amount to fourteen or fifteen.

In thus enlarging the house by removing a floor, the Odynerus displays two separate talents, the plasterer's and the car- 


\section{The Mason-Wasps}

penter's. Her knack for wood-working, moreover, is extremely useful in another circumstance, as we shall see. The Threehorned Osmia, also an enthusiastic partitioner of reeds, does not employ this means of obtaining a spacious lodging at small cost. I find that she always leaves the first party-wall intact, building the row of cells against it, however short the section may be. To make an opening in a slight barrier is not one of her methods. She could do it if she wished; for to gnaw through the ceiling of the cell on hatching and then through the general door of the nest is a more diffcult job. She possesses in her mandibles a tool powerful enough for the purpose; but she is not aware that a splendid gallery lies beyond the obstacle. How did the Odynerus learn, if she did not know from the beginning, what the Osmia, with her greater experience of the reed, does not know?

Apart from the ingenious device of breaking down the party-wall in order to enlarge the premises, the Odynerus is the Osmia's equal as a plasterer and partitionbuilder. The results of the two industries resemble each other so closely that we should easily confuse them if we merely examined the structure. We find in both 


\section{The Nest-building Odynerus}

cases, at irregular intervals, the same partitions, the same round disks of fine earth, of mud gathered wet on the brink of an irrigation-ditch or stream. Judging from the appearance of the materials, I imagine that the Odynerus has fetched her clay from the banks of the neighbouring torrent, the Aygues.

Identity of construction is maintained even in details which $I$ had at first regarded as a feat peculiar to the Osmia. Let us recall her compartment-building secret. If the reed be of middling diameter, the cell is first stocked with provisions and next bounded in front with a partition run up then and there, without any pause in its construction. If the reed, without being excessively wide, be of a certain thickness, the Osmia, before stowing away the victuals, gets to work on the front partition, providing it with an opening at the side, a sort of service-hatch, through which the honey is more easily discharged and the egg more easily placed in position. Well, this secret of the service-hatch, which was revealed to me by the glass tube, is as well-known to the Odynerus as to the Osmia. She, too, in the bigger reeds, finds it to her advantage to close the larder in front before 


\section{The Mason-Wasps}

bringing the game; she shuts the cell with a door provided with a sort of wicket, through which the victualling and the laying are done. When everything is finished inside, a plug of mortar closes the hatch.

I did not of course see the Odynerus working at her partition with its wicketdoor, as I saw the Osmia performing in my glass tubes; but the work itself speaks quite plainly of the method followed. In the centre of the partitions in the medium reeds there is nothing in particular to be seen; in the centre of the partitions in the larger reeds there is a circular aperture, afterwards filled with a plug, which always differs from the rest of the partition by projecting inwards and sometimes differs in colour. The thing is obvious: the small partitions are made in one spell, whereas the work on the larger ones is interrupted and then resumed.

As we see, it would be pretty difficult to distinguish the Odynerus' nest from the Osmia's, if our enquiries were confined to the cells. One characteristic, however, and not the least curious enables an attentive eye to tell the owner without opening the reed. The Osmia closes her dwelling with a thick plug of earth similar in nature to that em- 


\section{The Nest-building Odynerus}

ployed for the partitions. The Odynerus, it goes without saying, does not neglect this means of defence': she, too, makes a solid stopper; but to the unsophisticated method of the Osmia she adds the resources of a more highly-finished art. Over her earthen stopper, a thing liable to be spoilt by frost and damp, she spreads, on the outside, a good thick layer of a composition of clay and chopped-up woody fibres. It matches the red wax with which we seal the corks of our bottles.

These fibres, which resemble the remains of a coarse tow retted by long exposure to the air, I should be inclined to look upon as taken from reeds spoilt by the rain and bleached by the sun. The Odynerus planes them off in shavings, which she afterwards crumbles by chewing them. This is how the Common Wasps and the Polistes work on soft dead wood, when gathering the raw material for their brown paper. But the reed-dweller, who has no intention of employing her scrapings for paper-making, does not cut up these fibrous particles anything like so finely. She contents herself with breaking them up and unravelling them a little. Mixed with thick mud, the same as that of the partitions and the final plug, 


\section{The Mason-Wasps}

they make an excellent loam, which is far less liable to go to pieces than unmixed clay would be. The efficacy of this ingenious stucco is evident. After some months of exposure to the inclemencies of the weather, the Osmia's door, made of earth only, is very much dilapidated, whereas the Odynerus' door, covered on the outside with a layer of fibrous composition, remains intact. Let us credit the Odynerus with inventing and patenting the loam covering and proceed.

After the nest, the victuals. One sort of game alone is served to the Odynerus' family: this is the larva of the Poplar Leafbeetle (Chrysomela populi, Lina p.), a larva which, in company with the adult insect, ravages the poplar-leaves at the end of spring. Consulted merely by our taste, the Odynerus' game is anything but enticing in shape and still less in smell. It is a plump, thickset grub, with a bare, fleshwhite skin covered with several lines of glossy black dots. The abdomen, in particular, has thirteen rows of these black spots, namely, four on the top, three on each side and three underneath. The four dorsal rows vary in structure: the two in the middle consist of plain black specks; those 


\section{The Nest-building Odynerus}

on either side consist of little pimples, each shaped like a truncated cone with a minute opening at the top. One of these cones rises on the right and left of each abdominal segment, except the last two; there is also one on the right and one on the left of the metathorax and mesothorax. These two are larger than the others. There are nine pairs of perforated pimples in all.

If we tease the creature, we see welling up from the bottom of these several little craters an opalescent liquid, which runs and spreads all over the larva. It has a strong smell of bitter almonds, or rather of nitrobenzene, commonly known as essence of mirbane, a powerful and most repulsive smell. The discharge of this substance is a means of defence. We have only to tickle the insect with a straw or to grip one of its legs with the tweezers and the eighteen scent-bottles at once begin to work. Whoso handles the grub will find his fingers stink and will throw away the noisome perfumer in disgust. If the Chrysomelalarva's object in placing nine pairs of nitrobenzene-stills on its back was to repel man, it has, I admit, thoroughly succeeded.

But man is the least of its enemies. Far more formidable is the Odynerus, who 


\section{The Mason-Wasps}

seizes the scented creature by the skin of the neck and, despite its sprays of perfume, dispatches it with a few stings. This was the bandit against whom, above all, it should have defended itself; and the poor grub has not been happily inspired in this respect. Considering the huntress' exclusive taste for this sort of game, we must presume that the Chrysomela's drug-shop possesses a delicious aroma in the Odynerus' opinion. The defensive secretion becomes a deadly bait. Even so with other means of protection: each advantage invariably has some corresponding disadvantage.

I have read, I forget where, the story of certain South-American Butterflies, some of whom tasted bitter, others not. The first were respected by the birds because of their bitterness; the second were eagerly swallowed. What did the persecuted insects do? Unable to acquire the disagreeable flavour of the bitter ones, they at least imitated their shape and their costume. And the birds were taken in by the fraud.

This was put forward as a striking proof of evolution in view of the struggle for life. I am repeating the story more or less correctly, as it lingers vaguely in my memory, for I have never attached more import- 


\section{The Nest-building Odynerus}

ance than they deserve to pretty inventions of this kind. Is it really certain that the pungent Butterflies escaped destruction because of their taste? Might there not be, among the birds, a few passionate lovers of bitters, to whom the defensive flavour was, on the contrary, an added lure? My two acres of pebbles tell me nothing of things Brazilian; nevertheless I learn within their four walls that a grub of detestable flavour, of the most repulsive aroma, has, like the others, its appointed consumers and very zealous consumers at that. If the struggle for life made it acquire its scentbottles, then the struggle for life is a fool: it should have left the creature without them. In this way the enemy most to be feared, the Odynerus, who is attracted by the smell, would have been avoided.

The non-pungent Butterflies teach us something more. In order to protect themselves from the birds, they have imitated the pungent ones' costume. Pray, then, let some one tell us why, among so many naked larvæ on which the little birds feast, not one has thought of assuming the Chrysomela's black-buttoned overall. Unable to provide themselves with stinking retorts, they should at least possess a colour- 
The Mason-Wasps

able imitation, in order to put their persecutors off. The simple creatures! It never entered their heads to protect themselves by mimesis! We will not blame them; it is not their fault. They are what they are; and no bird's beak will make them change their costume.

The Chrysomela's defensive fluid has a look of essential oil: it discolours paper with a semitransparent stain which disappears by evaporation. Its colour is opalescent; its flavour is horrible; its odour is excessively strong and may be compared with that of the nitrobenzene of our laboratories. Were it not that I lack the leisure and the apparatus, I would gladly undertake a little research-work into this singular product of animal chemistry, which, I think, is quite as worthy of exploration by our tests as the milky exudations of the Salamander or the Toad. Meanwhile I commend the problem to the chemists.

In addition to the eighteen flasks of essential oil, the grub possesses yet another protective device, which is at once defensive and locomotory. The end of the intestine expands, at the insect's pleasure, into a large amber-coloured pimple, whente oozes a colourless or very pale-yellow liquid. I 


\section{The Nest-building Odynerus}

find it difficult to distinguish the odour of this liquid, because the strip of paper on which I collect it is always infected by the creature's mere touch. Nevertheless I seem to recognize, in a fainter degree, the smell of nitrobenzene. Can there be any connection between the product of the dorsal flask and that of the intestinal pimple? There very well may be. I suspect, also, that it possesses special virtues, for the Odynerus, who is a fine judge in such matters, will tell us presently how greatly she appreciates this liquid.

Before taking the evidence of the huntress, let us note that the grub employs its anal pimple to móve along with. Too short in the legs, it is a sort of cripple using its inflated stern as a lever. Another fact, whose interest will appear at the proper time, is that, at the moment of the metamorphosis, the larva fastens itself by the anus to a poplar-leaf. The larval skin is pushed back while it remains clinging; and the nymph appears half-sheathed in this slough. The nymph in its turn splits; the perfect insect releases itself; and the two cast-off suits of clothes, one partly enclosed within the other, retain their place on the leaf, fastened to it by the anal extremity. 


\section{The Mason-Wasps}

The nymphosis takes about twelve days in all. It would be irrelevant to linger any longer over the larva of the Chrysomela; the little which it is expedient to say must not exceed the limits of my subject, which is the story of the Odynerus.

We know the game grazing on its poplarleaf in the sun; let us see it stowed away in the larder. I count the number of head in a reed-stump occupied by seventeen cells, with their stores of food complete, or nearly so, some still containing the egg, the others a young larva attacking its first morsel. In the best-provisioned cells ten grubs are packed together; in those least well-supplied there are only three. I perceive, moreover, that, generally speaking, the abundance of provisions diminishes in the upper and increases in the lower stories, though the order of progression is not always very exact. The varying ration of the two sexes is probably responsible: the males, which are smaller and more forward, are given the upper chambers, with a frugal bill of fare; the females, which are larger and more backward, are given the lower chambers, with a plentiful table. Another reason, I think, contributes to these variations in number, namely, the size of the 


\section{The Nest-building Odynerus}

game, which is more or less young, more or less plump.

Whether big or small, all the head of game are absolutely motionless. Armed with a magnifying-glass, I watch in vain for any oscillation of the palpi, any quivering of the tarsi, any pulsation of the abdomen, symptoms of life so frequently observed in the victims of the predatory Wasps. There is nothing, ever. Can the larvæ stabbed by the Odynerus be really dead? Can the provisions consist of actual corpses? By no means: their profound inertia does not preclude a remnant of life. The proofs are striking.

To begin with, inspected cell by cell, my bundle of reeds tells me that the big larvæ, those which have acquired their full development, very often adhere by their hinder part to the walls of the cell. The meaning of this detail is evident. Captured when the metamorphosis was at hand, the grub, despite the blows of the stiletto, has made its usual preparations: it has hung itself firmly to the adjoining support, the earthen partition or the tube of the reed, just as it fastens itself to the poplar-leaf. The creature is so fresh in appearance and its anal adhesion is so accurate that I ac- 


\section{The Mason-Wasps}

tually hope to see the victim's skin split and the nymph appear. My hope is not at all exaggerated; it is based on facts no less curious which I shall describe later. Events did not respond to the probabilities on which I all but relied. When removed from the charnel-house with their point of support and put in a safe place, none of the larvæ settled for the nymphosis went beyond the preparatory action. This action in itself, however, is eloquent enough: it tells us that a remnant of life faintly animates the grub, since it retains power to make the necessary arrangements for the transformation.

That the grub is no corpse is revealed in another manner. I place in glass tubes, with a plug of cotton, twelve larvæ removed from the Odynerus' larders. The sign of latent life is the creature's freshness and its hue, a soft pinky white; the sign of death and corruption is a brown colouring. Well, eighteen days later one of the grubs begins to turn brown. A second is seen to be dead in thirty-one days. In forty-four days, six are still fresh and full. Finally, the last continues in good condition for two months, from the 16 th of June to the $15^{\text {th }}$ of August. It goes without saying that, 


\section{The Nest-building Odynerus}

under the same conditions, larvæ which are really dead and unbruised, larvæ asphyxiated with bisulphide of carbon, turn brown in a few days.

As I should have expected, the layingpeculiarities of the Nest-building Odynerus are precisely identical with those of $O$. reniformis, the object of my earlier observations. I again witness, with the satisfaction that results from verifying an interesting fact, the curious arrangements already described. The egg is laid first, right at the back of the cell. Next comes the stacking of the provisions in the order of capture. In this way the eating proceeds from the oldest to the most recent.

I was above all anxious to ascertain whether the egg was pendulous, that is to say, whether it hung by a thread at one point of the cell, in accordance with what I had learnt from the Eumenes and from O. reniformis. A kinswoman of the latter must, I felt certain beforehand, conform to the method of the suspension-cord; but there was reason to fear that the journey from Orange and the jolting of the cart might have broken the delicate pendulum. I recalled my anxieties, my minute precautions, during the removal of the cells with 


\section{The Mason-Wasps}

the egg of $O$. reniformis swinging from the ceiling. The cart, ignorant of its precious burden, might have undone everything.

But no, to my great surprise. In most of the cells which were sufficiently recent I find the egg in place, slung sometimes from the arched roof of the reed, sometimes from the upper edge of the partition, by a thread which is just visible and about one twentyfifth of an inch long. The egg is itself cylindrical and measures about an eighth of an inch. The reeds, opened wide and placed in glass tubes, enable me to witness the hatching, which takes place three days after the closing of the cell and probably four days after the laying.

I see the new-born grub enclosed almost wholly, head downwards, in the sheath provided by the pellicle of the egg. Very slowly it slides forward in this scabbard and the suspension-cord stretches to the same extent. It is extremely fine in the part consisting of the original thread, but very much thicker in the portion resulting from the slough of the egg. The grub's head reaches the nearest piece of game at one point or another; and the fragile creature takes its first mouthful. If anything startles it, if I tap the reed, it lets go and 


\section{The Nest-building Odynerus}

withdraws a little way into the sheath of the egg; then, reassured, it once more glides forward and resumes the point attacked. At other times a jerk leaves it indifferent. This suspension-stage of the new-born larva continues for about twenty-four hours, after which the grub, now somewhat fortified, lets itself drop and eats in the ordinary manner. The victuals last it for twelve days. Immediately afterwards comes the working of the cocoon, in which the insect remains, a yellow larva, until next May. It would be tedious to follow the Odynerus in its career of eating and weaving. The consumption of dishes highly spiced with nitrobenzene and the spinning of the cocoon, of a fine ambercoloured fabric, involve nothing so remarkable as to deserve special mention.

Before leaving this subject, I will state a problem which the pendulous egg sets to the embryogenist. Every insect's egg, if cylindrical in form, has two poles, the front and back, the cephalic and the anal pole. By which of the two does the insect see the light?

By the hinder pole, the Eumenes and the Odyneri tell us. The end of the egg fastened to the wall of the cell was evidently the first to issue from the oviduct, in view 


\section{The Mason-Wasps}

of the mother's absolute need first to glue the suspension-thread somewhere, before abandoning her egg to space. In the ovarian tubes and in the oviduct, which are too narrow to allow of an inversion, the anal pole therefore passes first. Pointing in the same direction as the egg, the newborn grub will thus hang head downwards, with its hinder end uppermost, at the end of its thread.

By the front pole, the Scolix, the Spheges and the Ammophilæ in their turn reply, as do all the Hunting Wasps that fix the egg to some portion of the victim. It is, indeed, always by the cephalic end that the egg adheres to the prey, at a definite point selected by the mother's prudence; for the safety of the nurseling and the preservation of the victuals demand that the first bites shall be taken here and here only. For the same reasons as above, the extremity fastened to the game has emerged into the light of day before the other.

Both these opposite testimonies are equally truthful. According as its destiny is to be glued to the wall of the cell or to be kept away from it on another support, the egg takes its plunge into life by the front pole or the rear pole, which requires 


\section{The Nest-building Odynerus}

an inverse direction in the ovaries and the oviduct. In this manner the new-born grub always has its food under its mandibles; and its utter lack of experience does not expose it to the danger of death from inanition in front of a heap of provisions which its mouth would not yet be able to seek and find. There is the problem. I beg and entreat the embryogenists to solve it, without reference to preordination, with the sole aid of protoplastic energy.

To know the Odynerus in the privacy of her home was not enough: the thing was to see her also at work as a huntress. How does she capture her game? How does she operate on it, in order to keep it fresh while deprived of life and movement? What is her surgical method? As, for the moment, I knew of no smallest colony of the Chrysomela's persecutor in my neighborhood, I put the matter to Claire. She was on the spot, in daily contact with the Hen-house where the memorable events that form the subject of this essay occurred; and - a most important circumstance - I knew her to be both quick-witted and willing. She accepted the burdensome task with enthusiasm. I, on my side, was, if possible, to attempt certain observations with the cap- 


\section{The Mason-Wasps}

tive insect. So as not to influence each other in our appreciation of facts which, by their rapidity, might leave room for doubt, we each agreed to keep our results secret until we were both certain of our data.

Fully instructed as to what to do, Claire begins. She soon discovers on the banks of the Aygues some poplars covered with Chrysomela-larvæ. From time to time an Odynerus arrives, alights upon a leaf and goes off again with her capture in her legs. But things are happening too high up; detailed inspection of the struggle between the huntress and the victim is impracticable. Moreover, the appearances of the Odynerus on the tree which was being watched among so many others, all equally propitious to the chase, occur at long intervals, which try the patience beyond all bounds. Tenacious in her desire to see, to learn and to be useful to me, my zealous collaborator bethinks herself of an ingenious expedient. A young poplar, with a wealth of Chrysomelæ, is pulled up, together with the lump of earth clinging to it. Lavish precautions are taken to avoid the shocks which, during the uprooting and the removal, might cause the herd of larvæ to drop off. The business is so successfully done that the tree 


\section{The Nest-building Odynerus}

arrives without a hitch at its destination, in front of the Hen-house. It is put back in the earth immediately facing the reeds wherein the Odynerus makes her dwelling. No matter whether it takes root again or not, provided that the little tree keep fresh for a few days with abundant watering: that is all that is wanted.

After installing her observatory, Claire proceeds to lie in wait, hiding behind some branches beside the poplar, whose foliage is in full view. She watches in the morning; she watches when the heat of the day has come; she watches in the afternoon. Next day, she begins again; on the day after that, she is still at it; and so she continues until at last fortune smiles upon her. O blessed patience, of what are you not capable! The swarm of Odyneri, out in search of larvæ, were, on their return, warned by the smell of nitrobenzene of the presence of the transplanted and game-laden poplar. Why make distant expeditions when the quarry abounds outside one's door? The little tree was extensively exploited. Under such conditions the huntress was not long in revealing the secret of her tactics. Over and over again Claire witnessed the act of murder by the dagger. But she paid dearly for satisfy- 


\section{The Mason-Wasps}

ing our common curiosity; she had to keep her room for several days as a result of sunstroke. For that matter, she was prepared for the misadventure, well knowing, from my own example, that this is the assured reward of observations made beneath an implacable sun. May the eulogies of science repay her for a little headache! The results of her watches agreed at all points with those of my own. I shall explain them by telling what I saw myself.

Now for my turn. When the bundle of reeds selected by the Odyneri reached me, I was occupied with a most interesting question, as will be proved by the details reserved for another chapter. ${ }^{1}$ I was endeavouring to make the various Hunting Wasps, the species of whose prey was known to me, operate under a wire cover in my insect laboratory. This would determine the precise spots into which the sting was driven. My captives, confronted with their ordinary game, for the most part refused to unsheathe their weapons; others, less intent upon outdoor hunting, accepted the offer and stabbed their victims under my magnifyingglass. Why should not the Nest-building Odynerus be among these bold ones?

1 Not yet published in English.-Translator's Note. 208 


\section{The Nest-building Odynerus}

We will try. I have plenty of Chrysomela-grubs, received from Orange; I keep them under a wire-gauze dome, with an eye to their metamorphoses and their perfumestills. The game is at hand; the huntress is lacking. Where shall I catch her? I have only to ask Claire, who will hasten to send her. This is a sure expedient, but I hesitate to employ it: I fear lest the insect should reach me demoralized by the jolting of the cart and the tedium of a long captivity. To this bored and wearied creature an encounter with the Chrysomela will almost surely be a matter of indifference. I must have something better: I want the insect captured that moment with its aptitudes in their prime.

In front of my door is a field of yellow fennel-flower, an ingredient of that illfamed liquor, absinthe. From its umbels Wasps, Bees and Flies of all sorts drink their fill. Let us take the net and see. The banqueters are numerous. I inspect the rows of plants amid the drinking-songs, the buzzing and the shrilling of the insects. Praise the Lord, here is the Odynerus! I catch one, I catch two, I catch six of them and I hurry back to my workroom. Fate is favouring me beyond my desires: my 


\section{The Mason-Wasps}

six captures belong to the Nest-building Odynerus and all the six are females. Any one passionately interested in a problem and suddenly discovering the data required for its solution will understand my emotion. The joy of the moment has its anxious side: who knows what turn things will take between the huntress and the quarry? I shift an Odynerus and a Chrysomela-larva into a bell-glass. To stimulate the assassin's ardour, I set the glass cage in the sun. Here is the story of the drama, told in detail.

For a good quarter of an hour, the captive clambers up the sides of the bell-glass, crawls down again and up again, seeking an outlet whereby to escape, and seems to pay no attention to the game. I was already despairing of success when suddenly the huntress falls upon the larva, turns it over, belly upwards, clasps it and stings it thrice in succession in the thorax, particularly under the neck, in the median region, a point at which the sting is more insistent than elsewhere. The close-clasped larva does its utmost to protest, emptying its scent-bottles and oiling itself with petrol; but these defensive tactics have no effect. Indifferent to the heady perfume, the Odynerus performs 


\section{The Nest-building Odynerus}

her operation, wielding her lancet with the same certainty as if the patient were scentless. Thrice the sting is driven in, to kill the motor nerves in the three ganglia of the thorax. I repeat the experiment with other subjects. Few refuse to attack the prey; and each time three stings are administered with marked insistence at the point under the neck. What I saw under artificial conditions Claire, on her side, saw under conditions of liberty, in the open air, on the leaves of the transplanted poplar. The two collaborators, she and I, arrived at precisely the same result.

The operation is rapidly performed. Then the Odynerus, while dragging her prey along, belly to belly, munches at its neck for a considerable time, but without causing any wound. This action may well be equivalent to the practice of the Languedocian Sphex and the Hairy Ammophila, ${ }^{1}$ when, without inflicting a bruise, the one nibbles at the neck of her Ephippiger and the other at that of her Grey Worm, in order to compress and paralyse the cervical ganglia. I of course take possession of the torpid larvæ. The victim is absolutely in-

1 The Hunting Wasps: chaps. viii. to $x$. and xviii.Translator's Note. 


\section{The Mason-Wasps}

ert, save for a slight quivering of the legs, which soon ceases. When laid upon its back, the larva no longer stirs. It is not dead, however; that I have been able to prove. Its dull vitality is affirmed in another manner. During the first few days of this lethargy which knows no awakening, droppings are ejected until the intestine is empty.

On renewing my experiments, I witness something so singular that I am at first baffled. This time the prey is seized by the anal extremity and the sting is driven several times into the last segments, underneath the abdomen. This is the usual operation reversed and performed upon the hinder segments, instead of those of the thorax. The surgeon and the patient, who are head to head in the normal method, are in the present instance head to tail. Can it be by inadvertence that the operator is confusing the two ends of the grub and stinging the tip of the abdomen under the impression that she is stinging the neck? I believe it for a moment, but am soon undeceived. Instinct does not make mistakes of this sort.

For now, having finished thrusting with her sting, the Odynerus clasps the creature 


\section{The Nest-building Odynerus}

and begins slowly, with great bites of the mandibles, to munch the last three segments, on the dorsal surface. A manifest gluttony accompanies these bites; all the mouth-parts are brought into play, as though the insect were feasting on some exquisite dish. Meanwhile the grub, bitten to the quick, desperately works its short legs, whose activity is not at all diminished by the stings administered behind; it struggles violently, protesting with its head and mandibles. The other takes no notice and continues gnawing at the larva's rump. This lasts for ten or fifteen minutes; then the bandit releases the sufferer and leaves it where it lies, without troubling about it any further, instead of carrying it with her as she would not fail to carry game intended for the nest. Soon afterwards, the Odynerus begins to lick her fingers, as though she had been consuming some toothsome dainty: time after time she passes her tarsi between her mandibles; she is washing her hands after rising from table. What has she been eating? I must once more watch the epicure squeeze the juice from the rump.

Ever obliging, provided that I practise a little patience, my six captives, one after the other, operate on the Chrysomela-larvæ, at 


\section{The Mason-Wasps}

one time in front, as game for the family, at another behind, as a little addition to their own diet. The honey with which I serve them on spikes of lavender does not make them forget this horrible treat. The tactics employed in obtaining it, though the same in the general aspect, vary in detail. The larva is always seized by the hinder end and the stings are administered in succession from back to front, on the ventral surface. Sometimes the abdomen only is attacked, sometimes the thorax also, when the victim is deprived of all movement. Evidently the object of these stings is not the immobility of the larva, since the latter can move quite well, ambling along, wounded though it be, when the sting has not gone higher than the abdomen. Inertia is indispensable only in the case of victuals intended for the cells. If the Odynerus is working on her own behalf and not for her family, it matters little to her whether the grubs whose dainties she covets struggle or not; it is enough if all resistance in the part to be exploited is abolished by paralysis. This paralysis, moreover, is quite accessory; and each huntress neglects or practises it at will, bearing more or less forward, without any fixed rule. When the sated Odynerus re- 


\section{The Nest-building Odynerus}

leases the grub whose rump she has been chewing, it is sometimes therefore inert, like those intended for the cells, and sometimes endowed with almost as much activity as the untouched grubs, from which it differs only by the absence of its anal pimple, its support which reminds us of a cripple sitting in a bowl.

I examine the helpless ones. The anal blister has disappeared, nor can I make it reappear by squeezing the tip of the abdomen with my fingers. For the rest, in the place of this blister my pocket-lens shows me torn, rugged tissues; the end of the intestine is in tatters. Every elsewhere all around are bruises and contusions, but no gaping wounds. It is with the contents of the blister then that the Odynerus so deliciously slakes her thirst. When she munches the last two or three segments, she is milking the grub after a fashion; by means of the pressure, which favours the paralysis of the abdomen, she makes the rectal humour flow into the pocket, which she then rips open in order to sip the contents.

What is this humour? Some special product, some mixture of nitrobenzene? I cannot say for certain. I know only that the insect employs it in self-defence. When 


\section{The Mason-Wasps}

frightened, it exudes it to ward off the assailant. The anal reservoir begins to work when the first little drop appears from the scent-bottles. What shall we say of this protective device which becomes the cause of excruciating torture? Unsophisticated creatures, acquire the power of stinking, after this; distil benzene; become bitter if you were not bitter before: you will always find a devourer to scrunch you, an epicure to nibble your rump! South-American butterflies, pray take note!

I will not close the lamentable history of the Chrysomela-grub without telling what becomes of the creature after this horrible mutilation. The complete inertia produced by the thoracic injuries has nothing to teach us that we do not already know from the facts perceived in the larvæ destined for the cells. We will therefore consider the case in which the grub is stung three or four times at the tip of the abdomen only. I secure the creature when the Odynerus abandons it, after greedily munching the last three segments and scraping out the end of the intestine, whose defensive and locomotory pimple has disappeared. These three segments are bruised and of a sickly colour; but I cannot discover the least rent in the skin. The ab- 


\section{The Nest-building Odynerus}

domen is paralysed. The insect no longer uses its anal lever when walking. The legs are perfectly mobile and the grub employs them: it crawls, it drags itself along, progressing with a vigour which would be normal but for the obstruction of the hindquarters. The head also moves; the mouth-parts snap as usual. Apart from the paralysis of the abdomen and the mutilation of the rectum, the victim is in every respect the same as the lusty larva, browsing peacefully on the poplar-leaf. We have here a magnificent demonstration of the principle before which certain peevish objections are bound to fall to the ground: the effect of the sting is not felt, at least not at first, except at the points attacked. The sting strikes the nerve-centres of the abdomen and the abdomen is paralysed; it spares the thorax and the legs and head both remain active.

Ten hours after the operation, I examine the grubs again. The hind-legs are tremulous and are no longer of use for locomotion. Paralysis is overtaking them. Next day, they are inert; so are the middle legs. The head and the fore-legs are still working. On the day after, the whole grub is motionless, except the head. Lastly, on the fourth day, the creature is dead, really 


\section{The Mason-Wasps}

dead, for it shrivels, dries up and goes black, while the larvæ subjected to the thoracic operation with a view to being used for provisions remain full and fresh-coloured for weeks and months. Did the grub die of its stings in the abdomen? No, for the others, stung in the thorax, do not die. It is the Odynerus' cruel tooth and not the sting that killed it. With the tip of the abdomen crushed under the mandibles and the intestinal capsule pulled out by the roots, life has ceased to be possible. 


\section{CHAPTER IX}

INSECT GEOMETRY

$\mathrm{HE}$ industry of insects, especially that of
the Bees and Wasps, abounds in tiny marvels. Newly manufactured with the cotton supplied by various fluff-covered plants, the nest of certain Anthidia forms an exquisitely graceful pouch. It is accurately fashioned, white as snow, pleasing to the eye and softer to the touch than Swan'sdown. The Humming-bird's nest, a bowl hardly half the size of an apricot, is by comparison a piece of clumsy felt.

But this perfection is of brief duration. The artist is hampered by the exigencies of the space at her disposal. Her workshop is a chance shelter, a tunnel incapable of modification, which she has to use as she finds it. In this narrow retreat, therefore, the cotton purses are placed in a row, each compressing the others and distorting their form; they are welded at either end to their neighbours, till the whole becomes a lumpy pillar moulded to the volume of the container. For lack of space, the weaver has 


\section{The Mason-Wasps}

been unable to continue her textile fabric in accordance with the exquisite design dictated by her instinct. A length of rope, of indifferent merit, takes the place of the superb masterpiece of felt which the Anthidium would have created had she been working at isolated cells.

The Chalicodoma of the Walls, when building on a pebble, first raises a turret of faultless geometrical proportions. The dust scraped from the hardest spots in the highways and kneaded with saliva provides the mortar. To make a more solid job of things and also to economize cement, which takes a long time to collect and prepare, tiny bits of gravel are encrusted in the outer surface before the material sets. In this way the initial building becomes a rustic rockwork fortress, which is quite pretty to look at.

Using her trowel freely, the Mason-bee has builded after the prototype of her art, the cylinder adorned with a mosaic pattern. But other cells, at least a dozen, are to follow. Necessities now obtrude themselves from which the first piece of work was exempt; that which will soon be building is subordinated to that which is already built.

The solidity of the whole requires that 


\section{Insect Geometry}

the turrets leaning one against the other shall form a solid mass; and economy of material demands that the same partitionwall shall serve for two adjoining cells. These two conditions are incompatible with the regulation architecture, for grouped cylinders touch only along a line, affording no appreciable area of common partitionwall; they leave between them unoccupied intervals, which would prejudice the general stability. What does the builder do to remedy these two defects?

She abandons the normal outline and modifies it according to the space at her disposal. She alters the shape of the cylinder, not as regards the interior, which is still kept rounded to suit the convenience of the larva, the future inhabitant, but as regards the outer envelope, which becomes irregular and polygonal, filling the interstices with its angles.

The exquisite geometry promised by the turret first constructed is perforce abandoned when the complete edifice has to consist of a mass of cells in juxtaposition. Inexactness follows exactness even more noticeably at the end of the task. Anxious to strengthen her work and enable it to resist the attacks of the weather, the mason plas- 


\section{The Mason-Wasps}

ters it with a thick layer of mortar. Mosaic encrustations, round mouths, closed with a lid, and cylindrical bastions: all these disappear, submerged by the defensive casing. To look at, there is nothing left but a clod of dried mud.

The simplest of round bodies; the cylinder, stands likewise as the model for the jam-pot wherein the Pelopæus stacks her Spiders. With mud collected from the edge of a pool, the huntress begins by building a turret ornamented with diagonal lozenges. Unhampered by its surroundings, this structure, the first of the group, is of a perfection that gives us a high opinion of the builder's talent. It is fashioned like a segment of a twisted column. But other cells follow which, leaning one against the other, produce a mutual distortion. For the same reasons, namely, economy of material and general solidity, the beautiful ordonnance promised at the outset is wanting; crowding leads . to irregularity. A thick layer of cement ends by deforming the structure altogether.

Let us next consider the Agenia, who rivals the Pelopæus as a huntress and a worker in clay. She encloses the one Spider who forms her larva's ration in an 


\section{Insect Geometry}

earthenware shell hardly as large as a cherry-stone and embellished on the outside with a tiny milled pattern. This little gem of ceramics is an ellipsoid truncated at one end. When the structure stands alone, its accuracy of form is perfect.

But the potter's ware does not end with this. The place of refuge discovered in some crevice in a sunny wall is a valuable site, where the whole family will take up its abode. More preserve-jars are therefore fashioned, sometimes arranged in a row, sometimes collected in a group. Though constructed according to a fixed type, the ellipsoid, the new structures depart, some more, some less, from the ideal model. Welded together, end to end, they lose the smooth nipple of the ellipse and replace it by the sudden truncation of the barrel. When they are joined lengthwise, the belly of the barrel becomes flattened; when they are massed together anyhow, they become almost unrecognizable. Nevertheless, as the Agenia, unlike the Pelopæus, never covers her collection of pots with a casing, her work retains its distinctive features fairly well, thanks to the thoroughness with which the artist has stamped her trade-mark upon it. 


\section{The Mason-Wasps}

The pottery of the Eumenes is of a higher order: it favours a bulging cupola, like that of the Turkish kiosk or the Moscow basilica. At the summit of the dome is a short opening, like the mouth of an amphora, through which the caterpillars intended for the larva's consumption are introduced. When the larder is full and the egg slung from the ceiling by a thread, the bellmouthed neck of the cell is closed with a clay stopper.

As a rule, in these parts, E. Amadei builds on a big pebble. She adorns her cupola with angular bits of gravel, half buried in the plaster; on the stopper closing the mouth she places a little flat stone, or even a Snail-shell, selected from among the smallest. The earthenware casemate, well-baked by the sun, is supremely graceful.

Well, this elegant structure is doomed to disappear. Around her cupola the Eumenes builds others, using as walls what she has already built. Henceforth the exact circular form is no longer practicable. In order to occupy the reentrant angles, the new cells themselves become angular and assume an undecided, polyhedral form. Only the edges of the mass and the top retain traces of the regulation plan. The 


\section{Insect Geometry}

nest as a whole shows a nippled surface encrusted with broken flint. Each nipple corresponds with a cell, which may always be known by its amphora-like mouth, a part which is not misshapen, because it has been fashioned without impediment. In the absence of this certificate of origin, we should hesitate before recognizing the work of an expert dome-builder in the shapeless blob.

E. unguiculata does worse. After building, on some big stone, a group of cells which, in shape, ornamental encrustation and bell-mouthed neck, rival those of $E$. Amadei, she buries the whole under a layer of mortar. She imitates the Chalicodoma and the Pelopæus, who, for reasons of domestic safety, follow up artistic daintiness with the uncouthness of the fortress. Inspired by a system of æsthetics which nothing is able to evade, both insects begin by creating beauty; dominated by the fear of danger, they end by creating ugliness.

Other Eumenes, on the contrary, of smaller size, build cells which are always isolated and which often have the twig of a shrub for a support. The structure is a cupola, similar to those already mentioned, and, like them, provided with a graceful neck, but without the gravel mosaic. The 


\section{The Mason-Wasps}

tiny fabric, no bigger than a cherry, does not admit of this rustic ornamentation. The potter replaces it by a few specks of clay distributed here and there.

The Eumenes who build a succession of cells in groups are compelled to deform the chamber under construction according to the space left by those preceding it; for the beautiful curve of their original design they substitute, by force of circumstances, the unpleasing broken line. The others, those who build each cell in isolation, are far from perpetrating such inaccuracies. From first to last, as many as the establishment of the larvæ requires, now on this twig, now on that, the cells are built of an identical shape, just as though they had issued from the same mould. Now that nothing hinders the exact application of the rules, order returns and produces a series of structures which are no less perfect at the end than at the beginning.

If the insect were to build a general shelter, in which each larva had its individual box, what would this building, this common home of the family, be? On condition, of course, that no obstacle intervene, the work will always be correct in its geometry, which will vary according to the builder's speci- 


\section{Insect Geometry}

ality. I could draw you a child's balloon than which none prettier was ever inflated in toyland, or, for that matter, in fairyland; and it would be exactly like the nest of a Median Wasp (Vespa media, De Geer). The person who gave me this marvel found it hanging from the lower edge of a shutter which was left open for the greater part of the year.

Possessing liberty of action in all directions, except at the point of contact with the shutter, the Wasp followed the rules of her art without impediment. With a paper of her own manufacture, tough and flexible as the silk papers of China and Japan, she contrived to expand her work into a segment of an ellipsoid, with a cone added to it by means of a gentle curve. A like association of forms artistically combined is found in the Sacred Beetle's pears. ${ }^{1}$ The slender Wasp and the heavy Dung-beetle, employing dissimilar tools and materials, work after the same pattern.

Ill-defined spiral bands tell us how the Wasp went to work. With her pellet of paper-pulp in her mandibles, she moved downwards in a slanting direction, following the

1 Cf. The Sacred Beetle and Others, by J. Henri Fabre, translated by Alexander Teixeira de Mattos: chap. iv.Translator's Note. 


\section{The Mason-Wasps}

margin of the part already constructed and leaving as she went a ribbon of her material, still quite soft and impregnated with saliva. The work was discontinued and resumed hundreds and hundreds of times, for the supply was soon exhausted. The Wasp had to go to some woody stem hard by, a stem retted by the moist air and bleached by the sun, and scrape it with her teeth; she had to tear out its fibres, to divide them, unravel them and work them up into a plastic felt. When the pellet was removed, the Wasp hastened back to resume her interrupted ribbon.

There was even the collaboration of several builders. The foundress of the city, the mother, alone at the outset and absorbed by family cares, was able only to make a rough beginning of the roof; but offspring arrived, neuters, ${ }^{1}$ eager assistants henceforth charged with the continuing and enlarging of the dwelling, in order to provide the one mother with a lodging to contain the whole of her eggs. This gang of paper-makers, coming one by one to take part in the labour, or perhaps working without any common agreement, several at a time, at different points, so far from pro-

1 Sexually undeveloped females.-Translator's Note. 228 


\section{Insect Geometry}

ducing confusion, achieves perfect regularity. By slow degrees the spacious dome of the summit decreases in diameter; by degrees it tapers into a cone and ends in a graceful neck. Individual and almost independent efforts result in an harmonious whole. Why?

Because these building insects possess an innate geometry, an order of architecture which is known without bcing taught and which is constant in the same group, while varying as between one group and another. Just as much as the details of the organism, or perhaps even more so, this propensity to build according to certain determined rules characterizes the corporations known by the name of species. The Chalicodoma of the Walls has her earthen tower, the Pelopæus her twisted clay cylinder, the Agenia her urn, the Anthidium her cotton wallet, the Eumenes her open-mouthed cupola and the Wasp her paper balloon. And so with the others : each has her own art.

Our builders contrive and calculate before they set to work. The insect dispenses with these preliminaries; it knows nothing of the hesitations of apprenticeship. From the laying of the first stone it is a past master of its craft. It builds with 


\section{The Mason-Wasps}

the same accuracy and the same unconsciousness as those displayed by the mollusc, which coils its shell in a scientific spiral; if nothing hinders its aims, it always achieves a graceful and wisely economical structure. But, when a number of cells mutually hamper one another, the regulation plan, without being abandoned, undergoes alterations imposed by lack of space. Massing leads to irregularity. Here, as with us, liberty makes for order and constraint for disorder.

We will now open the nest of the balloonbuilding Wasp. Here is something that we did not expect. Instead of one envelope there are two, one enclosed within the other, with a slight interval between. There would have been even more, three or four of them, had not impatient hands, eager to bring me the masterpiece, culled it before it reached perfection. The nest is incomplete, as is proved by the single story of cells. A perfect Wasps'-nest would contain several stories.

No matter: such as it is, this work shows us that the chilly Wasp was acquainted with the art of preserving heat before we were. Physics teaches us the efficacy of a cushion of air, motionless between two walls, as a 


\section{Insect Geometry}

preventive against cooling; it recommends the use of double windows to maintain a mild temperature in our houses in winter. Long before the days of human science, the little Wasp, that passionate lover of warmth, knew the secret of multiple envelopes containing layers of air. With its three or four balloons, fitting within one another, her nest, hanging in the sun, must turn into a vapour-bath.

These paper containers are merely defensive works; the actual city, for which all the rest has been built, occupies the top of the dome. It consists at present of a single layer of hexagonal cells, open below. Later on, other, similar layers would have been added, descending in stages and each connected with its predecessor by little papier mâché columns. The aggregate of these layers, or combs, would supply not far short of a hundred cells, the lodgings of as many larvæ.

The method of rearing imposes on the Social Wasps rules unknown to the other builders. These latter store in each cell provisions - honey or game - apportioned to the grub's needs. The egg once laid, they close the cell. The rest does not concern them: the immured larva will find 


\section{The Mason-Wasps}

all around it the wherewithal to nourish itself and to thrive without outside help. Under these conditions, the irregular grouping of the cells is of trifling importance; disorder even is admissible, provided that the whole group be in a place of safety, if need be under the cover of a protective casing. Richly supplied with provender and tranquil in its crypt, none of the recluses expects anything from the outer world.

Among the Social Wasps a very different order of things obtains. Here the larvæ, from the beginning to the end of their growth, are incapable of sufficing unto themselves. Like little birds in the nest, they are fed by mouth; like babies in the cradle, they need constant attention. The workers, who are celibates expressly appointed to perform household labours, come and go incessantly, from bed-chamber to bedchamber; they awaken the sleepy larva, wash them with a lick of the tongue and disgorge, from mouth to mouth, the ration of the moment. So long as the larval state continues there is no end to these alimentary kisses between the nurselings gaping with hunger and the nurses returning from the fields, their crops swollen with pap.

Nurseries of this kind, which, in the 


\section{Insect Geometry}

case of various Social Wasps, number their cradles by the thousand, require ease of inspection, quickness of attendance and therefore perfect order. Whereas it makes no difference to the Chalicodomæ, the Eumenes and the Pelopxi whether their cells be grouped without any great precision, since, once provisioned and sealed, they will not be visited again, it is important to the Social Wasps that theirs should be arranged methodically, for otherwise the enormous household, degenerating into a turbulent mob, could not possibly be served.

To lodge the mother's inexhaustible supply of eggs, they have to build for her, within a limited space, the greatest possible number of cells, all of a capacity determined by the ultimate size of the larvæ. This condition exacts a strict economy of the available building-site. No empty gaps, therefore, which would take up unnecessary room and moreover compromise the general solidity of the structure.

Nor is this all. The business-man says to himself :

"Time is money."

The Wasp, no less busy, says to herself: "Time is paper; paper means a more spacious dwelling, holding a larger population. 


\section{The Mason-Wasps}

Let us not waste our materials. Each partition must serve two neighbouring apartments."

How will the insect set about solving its problem? To begin with, it abandons any circular form. The cylinder, the urn, the cup, the sphere, the gourd, the cupola and the other little structures of their customary art cannot be grouped together without leaving gaps; they supply no party-walls. Only flat surfaces, adjusted according to certain rules, can give the desired economy of space and material. The cells therefore will be prisms, of a length calculated by that of the larvæ.

It remains to decide what form of polygon will serve as the base of these prisms. First of all, it is evident that this polygon will be regular, because the capacity of the cells has to be constant. Once the condition obtains that the grouping must be effected without gaps, figures that were not regular would be subject to variation and would give different capacities in one cell and another. Now of the indefinite number of regular polygons only three can be constructed continuously, without leaving unoccupied spaces. These three are the equilateral triangle, the square, and the hexagon. Which are we to choose? 


\section{Insect Geometry}

The one that will approximate most closely to the circumference of a circle and hence be best adapted to the cylindrical form of the larva; the one that, with a containing wall of the same extent, will yield the greatest capacity, a condition essential to the free growth of the grubs. Of the three regular figures that can be assembled without vacant intervals, our geometry suggests the hexagon; and it is the hexagon and none other that is chosen by the geometry of the Wasps. The cells are hexagonal prisms.

Every high and harmonious achievement finds supersubtle minds that strive to degrade it. What has not been said on the subject of hexagonal cells, above all on the subject of the Bee's, which are arranged in a double layer and united at the base? Reasons of economy of both wax and space demand that this base shall be a pyramid formed of three rhombs with angles of fixed value. Scientific calculations tell us the value of these angles in degrees, minutes and seconds. The goniometer subjects the work of the Bee to examination and finds that the value is precisely calculated to degrees, minutes and seconds. The insect's work is in perfect agreement with the nicest speculations of our own geometry. 


\section{The Mason-Wasps}

There is no room for the glorious problem of the Bee-hive in these elementary essays. Let us confine ourselves to the Wasps. It has been said:

"Fill a bottle with dried peas and add a little water. The peas, in swelling, will become polyhedrons by mutual pressure. Even so with the Wasps' cells. The builders work in a crowd. Each builds at her own will, placing her work in juxtaposition to her neighbours'; and the reciprocal thrusts produce the hexagon."

A preposterous explanation, which no one would venture to suggest if only he had condescended to make use of his eyes. Good people, why not look into the early stages of the Wasp's work? This is quite easy in the case of the Polistes, who builds in the open, on a twig of some hedge-plant. In the spring, when the Wasps'-nest is founded, the mother is alone. She is not surrounded by collaborators who, vying with her in zeal, would place partition against partition. She sets up her first prism. There is nothing to hamper her, nothing to impose one form upon her rather than another; and the original cell, free from contact in every direction, is as perfect an hexagonal prism as the rest will be. The faultless geometry of 236 


\section{Insect Geometry}

the structure asserts itself from the outset.

Look again when the comb of the Polistes or any Social Wasp that you please is more or less advanced, when numbers of builders are at work upon it. The cells at the edge, most of them still incomplete, are free as regards their outer halves. So far as this part is concerned there is no contact with the preceding row of cells; no limit is imposed; and yet the hexagonal configuration appears as plainly here as elsewhere. Let us abandon the theory of mutual pressure: a single glance of the least discernment contradicts it flatly.

Others, with more scientific, that is to say, less intelligible ostentation, substitute for the contact of the swollen peas the contact of spheres which, with their intersections and by virtue of an unseeing mechanism, lead to the superb structure of the Bees. The theory of an order emanating from an Intelligence watchful over all things is, to their thinking, a childish supposition; the riddle of things is explained by the mere potentialities of chance. To these profound philosophers, who deny the geometrical Idea Which rules the forms of things, let us propound the problem of the Snail.

The humble mollusc coils its shell accord- 


\section{The Mason-Wasps}

ing to the laws of a curve known as the logarithmic spiral, a transcendental curve compared with which the hexagon is extremely simple. The study of this line, with its remarkable properties, has long delighted the meditations of the geometricians.

How did the Snail take it as a guide for his winding staircase? Did he arrive at it by means of intersecting spheres, or other combinations of forms dove-tailed one into the other? The foolish notion is not worth stopping to consider. With the Snail there is no conflict between fellow-workers, no interpenetration of similar, adjoining structures. Quite alone, completely isolated, peacefully and unconsciously he achieves his transcendental spiral with the aid of glaireous matter charged with lime.

Did the Snail even invent this cunning curve himself? No, for all the molluscs with turbinate shells, those which dwell in the sea and those which live in fresh water or on land, obey the same laws, with variations of detail as to the conoid on which the typical spiral is projected. Did the present-day builders accomplish it by gradually improving on an ancient and less exact curve? No, for the spiral of abstract science has presided over the scrollwork of their shells ever since 


\section{Insect Geometry}

the earliest ages of the globe. The Ceratites, the Ammonites and other molluscs prior in date to the emergence of our continents coil their shells in the same fashion as the Planorbes ${ }^{1}$ of our books.

The logarithmic spiral of the mollusc is as old as the centuries. It proceeds from the sovran Geometry Which rules the world, attentive alike to the Wasp's cell and to the Snail's spiral.

"God," says Plato, " is ever the great

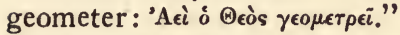

Here truly is the solution of the problem of the Wasps.

${ }^{1}$ A widely-distributed genus of Pond-snails.-Translator's Note. 


\section{CHAPTER X}

\section{THE COMMON WASP}

IN September, with my little son Paul, who 1 lends me his good sight and his artless attention, undisturbed as yet by anxious thoughts, I sally forth at a venture, questioning the edges of the foot-paths with my glance. At twenty yards' distance my companion has just seen rising from the ground, shooting up and flying away, now one and now another swiftly moving object, as though some tiny crater in eruption in the grass were hurling forth projectiles.

"Wasps'-nest!" he cries. "Sure as anything, a Wasps'-nest!"

We approach discreetly, fearing to attract the attention of the fierce community. It is indeed a Wasps'-nest. At the entrance to the vestibule, a round opening large enough to admit a man's thumb, the inmates come and go, busily passing one another in opposite directions. Brrrl A shudder runs through me at the thought of the unpleasant time which we should have were we to draw the attack of the irascible soldiery by too close an 


\section{The Common Wasp}

inspection. Without making further investigations, which might cost us dear, let us mark the spot. We will return at nightfall, when the whole legion will have come home from the fields.

The conquest of a nest of Common Wasps (Vespa vulgaris, LiNN.) would be a rather serious undertaking if one did not practise a certain prudence. Half a pint of petrol, a reed-stump nine inches long, a good-sized lump of clay or loam, ready tempered by kneading: such is my equipment, which I have come to consider the best and simplest, after various trials with less effectual means.

The asphyxiating-method is indispensable here, unless we employ costly expedients out of all keeping with my resources. The excellent Réaumur, when he wanted to place a live Wasps'-nest in a glass case, with a view to observing the habits of the inmates, had willing lackeys, seasoned to their painful job, who, allured by a handsome reward, paid for the scientist's gratification with their skins. I, who should have to pay with my own skin, think twice before digging up the coveted nest. I begin by suffocating the inhabitants. Dead Wasps do not sting. It is a brutal method, but perfectly safe.

Besides, I have no need to revise the ob$24 I$ 


\section{The Mason-Wasps}

servations of the Master, himself so capable an observer. My ambition is limited to certain matters of detail, which I shall be able to study with a small number of survivors. These I can spare by moderating the dose of asphyxiating-fluid.

I use petrol by preference because it is cheap and because its effects are less overwhelming than those of bisulphide of carbon. The question is how to introduce it into the cavity containing the Wasps'-nest. A vestibule, or entrance-passage, about nine inches long and very nearly horizontal, gives access to the underground chambers. To pour the liquid straight into the mouth of this tunnel would be a blunder that might have grievous consequences at the moment of excavation. So small a quantity of petrol would be absorbed by the soil on its way to the nest and would never reach its destination; and next day, when we might think that we were digging without risk, we should find an infuriated swarm under the spade.

The bit of reed prevents this mishap. Inserted into the gallery, it forms a watertight conduit and conveys the liquid to the cavern without the loss of a drop. A funnel is useful, as it enables us to pour the liquid quickly. The entrance to the dwelling is 


\section{The Common Wasp}

forthwith tightly stoppered with the lump of clay which we bring with us ready kneaded, for most often there is no water on the spot. We have now nothing to do but wait.

Carrying a lantern and a basket with the implements, Paul and I set out, at nine o'clock in the evening, to perform an operation of this sort. The weather is mild and the moon gives a little light. The farmhouse Dogs are bandying distant yelps; the Screech-owl is hooting in the olive-trees; the Italian Crickets ${ }^{1}$ are performing their symphony in the bushes. And we chat about insects, the one asking questions, eager to learn, the other telling the little that he knows. Delightful nights of Wasp-hunting, you well atone for our loss of sleep and make us forget the stings which are likely to incur!

Here we are! The pushing of the reed into the passage is the most delicate matter. Sentries may well emerge from this guardhouse and attack the operator's hand during the hesitation caused by the unknown direction of the gallery. The danger is provided for. One of us keeps watch; he will drive away the assailants with his handkerchief, should any appear. Besides, an idea is not

${ }^{1}$ Cf. The Life of the Grasshopper: chaps. xiv. and xvi. - Translator's Note. 


\section{The Mason-Wasps}

so very expensive if we acquire it at the cost of a swelling and a smart itching.

This time there is no mishap. The conduit is in place; it sends the contents of my flask streaming into the cavern. We hear the threatening buzz of the underground population. Quick, the wet clay, to close the door; quick, a kick or two of the heel upon the clod, to consolidate the closing! There is nothing more to be done. It is striking eleven; let us be off to bed.

Provided with a spade and trowel, we are back on the spot at dawn. Numbers of Wasps, belated in the fields, have been out all night. They will turn up as we are digging, but the chill of the morning will render them less aggressive; and a few flicks of the handkerchief will be enough to make them keep their distance. Let us hasten therefore, before the sun grows hot.

A trench of sufficient width to give us freedom of movement is dug in front of the entrance-passage, whose position is indicated by the reed, which remains where it was. Next, the perpendicular side of the ditch is carefully cut away in slices. Thus conducted, at a depth of some twenty inches, our digging at last reveals the Wasps'-nest intact, slung from the roof of a spacious cavity. 


\section{The Common Wasp}

It is indeed a superb achievement, as large as a fair-sized pumpkin. It hangs free on every side, except at the top, where various roots, mostly rootstocks of couch-grass, penetrate the thickness of the wall and fasten the nest firmly. Its shape is round wherever the softness and the homogeneous character of the ground have permitted a symmetrical excavation. In stony soil, the sphere becomes misshapen, a little more here, a little less there, according to the obstacles encountered.

A space of a hand's breadth is always left open between the paper monument and the sides of the subterranean vault. This is the wide street along which the builders move unhindered at their continual task of enlarging and strengthening the nest. The one lane by which the city communicates with the outer world opens into it. The unoccupied space under the nest is much greater. It is rounded into a big basin which allows the general wrapper to be enlarged as fresh layers of cells are added to those above. This receptacle, shaped like the bottom of a copper, is also the great cess-pool into which the multitudinous refuse of the Wasps'-nest falls and accumulates.

The size of the cavern raises a question. The Wasps themselves dug the cellar. Of 


\section{The Mason-Wasps}

that there is no doubt: cavities like this, so large and so accurately formed, do not exist ready-made. That the mother foundress at the beginning, working by herself and eager to get on quickly, availed heiself of some chance refuge, due perhaps to the excavations of the Mole, is possible; but the rest of the work, the making of the enormous crypt, was done by the Wasps alone. Then what has become of the rubbish, the mass of earth whose bulk would be that of a cube measuring some twenty inches on every side?

The Ant erects the excavated material into a cone-shaped hillock on the threshold of her abode. With her two or three bushels of earth, what a mound would not the Wasp achieve, if heaping were her habit! But far from it: she leaves not a scrap of rubbish outside her door; everything is perfectly tidy. What has she done with the cumbrous mass?

The answer is supplied by various peaceable insects which are easy to observe. Consider a Mason-bee clearing an old nest which she proposes to use; watch a Leaf-cutter cleaning out an Earth-worm's burrow in which to stack her leafy bags. Holding a trifle of some sort in their teeth, a shred of silky tapestry or a crumb of earth, they fly off 


\section{The Common Wasp}

at a furious speed, to drop their infinitesimal load at a distance. Then they immediately face about, return to the workshop and undertake a new flight out of all proportion to the result achieved. The insect, one would think, is afraid to encumber the site by merely brushing the tiny fragments away with its feet; it must take to its wings to disperse its insignificant sweepings afar.

The Wasps work in the same manner. There are thousands and thousands of them digging at the cellar and enlarging it as the need occurs. Each carrying her particle of earth in her mandibles, they gain the outer world, fly to a distance and drop their burden, some nearer, some farther away, in all directions. Thus distributed over wide areas, the excavated earth leaves no visible trace.

The material of the Wasps'-nest is a thin, flexible brown paper, streaked with paler bands, according to the nature of the wood utilized. Made in a single, continuous sheet, according to the methods of the Median Wasp (Vespa media), this substance would constitute an indifferent protection against the cold. But, while the balloon-maker understands the art of preserving heat by means of a cushion of air con- 


\section{The Mason-Wasps}

tained between several wrappers enclosed one within the other, the Common Wasp, no less versed in the laws of thermal science, arrives at the same result by different means. With her paper-pulp she manufactures broad scales which overlap loosely and are superimposed in numerous layers. The whole forms a coarse blanket, of a thick, spongy texture and well-filled with stagnant air. The temperature under such a shelter, in the hot weather, must be truly tropical.

The fierce Hornet (Vespa crabo, LinN.), chief of the Wasp clan by virtue of her strength and her warlike audacity, conforms to the same principles of the globular configuration and of air imprisoned between partition-walls. In the cavernous hollow of a willow or in the recesses of some empty granary, she manufactures a yellow, striped, very brittle cardboard, composed of an agglomeration of woody fragments. Her spherical nest is wrapped in an enclosure of broad convex scales, a sort of tiles which, welded to one another and arranged in multiple layers, leave between them wide intervals in which the air is held motionless.

To employ an athermous substance such as air, in order to check the loss of heat; to anticipate our manufacturers of eiderdown 248 


\section{The Common Wasp}

quilts; to give the containing walls of the nest the shape that encloses the greatest capacity within the smallest wrapper; to adopt as a cell the hexagonal prism, which economizes space and material; these are scientific actions that accord with the data of our physics and geometry. We are told that the Wasp, proceeding from improvement to improvement, worked out her sensible building for herself. I cannot believe this when I see the whole nest perish, a victim to my tricks, which would easily have been baffled if the insect possessed the least power of reflection.

These wonderful architects amaze us by their stupidity in the presence of a trifling difficulty. Outside their work of the moment there is a complete absence of all lucidity such as the progressive invention of the nest would demand. Of the various tests that assure me of this, I will mention the following, which is easily made.

The Common Wasp has chanced to set up her dwelling in the enclosure. The establishment is beside one of the walks. No member of the household dares venture in that part; it would be dangerous to go near it. We must rid ourselves of these bad neighbours, who terrify the children. It will also be a good thing to profit by this ex- 


\section{The Mason-Wasps}

cellent opportunity of experimenting with appliances which could not be used in the open fields, where the little country bumpkins would soon smash my glass to bits.

All that is required is a large chemist's bell-glass. At night, when all is dark and the Wasps have gone home, I place it over the entrance of the burrow, after first flattening the soil. To-morrow, when the Wasps resume their labours and find themselves checked in their flight, will they succeed in contriving a passage under the rim of the bell-glass? Will these sturdy workers, who are capable of digging a spacious cavern, realize that a very short subterranean tunnel will set them free? That is the question.

To-morrow arrives. The bright sunlight falls upon the glass container. The workers ascend in a crowd from under ground, eager to go in search of provisions. They butt against the transparent wall, tumble down, pick themselves up again and whirl round and round in a crazy swarm. Some, weary of dancing this continual saraband, alight on the ground, wander peevishly at random and then reenter their dwelling. Others take their places as the sun grows hotter. Well, not one of them, note this, 


\section{The Common Wasp}

not one of them scratches with her feet at the base of the treacherous circle. This means of escape is too far above their mental capacity.

A few Wasps have spent the night out of doors. Here they are, coming in from the fields. Round and round the bell-glass they fly; at last, after much hesitation, one of them decides to dig under the edge of the enclosing wall. Others are quick to follow her lead. A passage is opened without difficulty. The Wasps go in. I do not interfere with them. When all the loiterers have reentered the nest, I close the breach with some earth. The narrow opening, if seen from within, might help the Wasps to escape; and I wish to leave the prisoners the honour of inventing the liberating tunnel.

However poor the Wasp may be in judicious inspirations, escape has now become probable. Benefiting by their recent experience, the loiterers who have just entered will, I thought, set the others an example; they will teach them the tactics of digging at the base of the rampart.

I judged my diggers too hastily. Of example set and taken, of learning by experience, there is not a sign. Inside the bellglass not an attempt is made to employ the 


\section{The Mason-Wasps}

method which succeeded so well in the case of the home-comers. The insect population whirls round and round in the torrid atmosphere of the glass, but indulges in no enterprise. It flounders about, decimated from day to day by famine and the excessive heat. At the end of a week, not a creature is left alive. A heap of corpses covers the ground. Incapable of any innovation in its customs, the city has perished.

This inept behaviour reminds me of the story of the wild Turkeys as told by Audubon. ${ }^{1}$ A bait consisting of a few grains of millet lures them into a short underground passage, which leads to the centre of a wattled cage. When fed to repletion, the flock is ready to depart; but to use for their departure the way by which they entered, though it still yawns in the centre of the enclosure, is a manœuvre of too high an order for the stupid Turkeys. This path is dark, whereas daylight shines between the bars. The birds therefore revolve indefinitely against the trelliswork, until the trapper arrives and wrings their necks.

An ingenious Fly-trap is employed in our

1 John James Audubon (1780-1851), a noted American ornithologist of French descent, author of The Birds of America, which was published by subscription (18271830) at $\$ 1,000$ a copy. - Translator's Note. 


\section{The Common Wasp}

homes. It consists of a water-bottle with an opening at the bottom and standing on three low supports. Inside, some soap-suds form a ring-shaped lake around the orifice. A lump of sugar, placed beneath the entrance, acts as the bait. The Flies make for the sugar. On leaving it, seeing the light above them, they rise with a vertical flight and enter the trap, where they wear themselves out, beating their wings against the transparent wall. All perish by drowning, because they are incapable of the rudimentary notion of going out by the way they came.

Even so with the Wasps under my bellglass: they know how to get in, but do not know how to get out. On ascending from their burrow, they go to the light. Finding broad daylight in their transparent prison, they consider their aim accomplished. An obstacle checks their flight, it is true; no matter: the whole area is brightly lit up; and this is enough to delude the prisoners, who, despite the continual warning of their collisions with the glass, endeavour, obstinately and without attempting anything else, to fly farther in the direction of the luminous void.

The Wasps returning from the fields are in a different situation. They are passing 


\section{The Mason-Wasps}

from light to darkness. Moreover, even without the intervention of the experimenter's wiles, they are sure occasionally to find the threshold of their dwelling obstructed by fallen earth, the result of rain or of the feet of the passers-by. The next action of the homing Wasps is bound to follow: they search about, sweep, dig and end by finding the entrance-tunnel. This power of scenting their house through the soil and this eagerness to clear the doorway of their dwelling are innate aptitudes:-they form part of the resources bestowed upon the species for its preservation in the midst of daily accidents. Here there is no need of reflection or calculation: the earthy obstacle has been familiar to one and all since Wasps first came into the world. They therefore scrape and go in.

At the foot of the bell-glass, the same order of things obtains. Topographically, the position of the Wasps'-nest is perfectly well-known; but direct access has become impossible. What is to be done? After a brief hesitation, the process of digging and clearing is adopted according to ancient custom; and the difficulty is overcome. In short, the Wasp knows how to reenter her home, in spite of certain obstacles, because 


\section{The Common Wasp}

the action here accomplished conforms with what is always done in similar circumstances and does not call upon the shadowy intellect for any fresh gleam of light.

But she does not know how to get out, though the difficulty remains precisely the same. Like the Turkey of the American naturalist, she is defeated by this problem: to recognize as good for going out the road which was recognized as good for going in. Impatient to escape, both bird and insect rush frantically to and fro, exhausting themselves in their striving towards the light; and neither pays any attention to the underground passage, which would so readily give them their liberty. Neither of them thinks of it, because to do so would require a little reflection and would thwart the impulse of the moment, which is to flee far into the daylight. Wasps and Turkeys alike perish, rather than improve the present by the lessons of the past, when called upon to modify their usual tactics be it ever so slightly.

The Wasp has been extolled for inventing the round Wasps'-nest and the hexagonal cell, that is to say, for rivalling our geometricians in solving the problem of the forms which are most economical of space and material. Men attribute to her ingenuity the 


\section{The Mason-Wasps}

magnificent discovery of the surrounding wrapper cushioned with air, than which our own physicists could imagine no better provision against cold. And these superb inventions are supposed to have been achieved quite simply by the clumsy intellect which is unable to use an entrance-door as an exitdoor! Such marvels inspired by such ineptitude leave me profoundly incredulous. Actions of this kind have a higher origin.

We will now open the thick envelope of the nest. The interior is occupied by the combs, or disks of cells, lying horizontally and fastened one to the other by solid pillars. The number varies. Towards the end of the season it may be as many as ten, or even more. The orifice of the cells is on the lower surface. In this strange world, the young grow, sleep and receive their food head downwards.

For service-purposes, open spaces, with rows of connecting pillars, divide the various stories. Here is a continual coming and going of nurses, busily attending to their grubs. Lateral doorways, between the outer envelope and the stack of combs, give easy access to every part. Lastly, on one side of the wrapper, the open gate of the city stands, devoid of architectural adornment, a modest 


\section{The Common Wasp}

aperture lost among the thin flakes of the surrounding surface. Facing it is the underground vestibule leading to the outer world.

The cells of the lower combs are larger than those of the upper; they are set aside for the rearing of the females and the males, while those in the stories up above serve for the neuters, who are a little smaller. At first the community requires, before all else, an abundance of workers, of celibates exclusively addicted to work, who enlarge the dwelling and prepare it to become a flourishing city. Preoccupations for the future belong to a later stage. More capacious cells a re constructed, some intended for the males, others for the females. According to figures which I will give later, the sexed population represents about one-third of the whole.

Let us also observe that, in a Wasps'-nest which has reached an advanced age, the cells in the upper stories have their walls gnawed right down to the base. They are ruins of which naught remains but the foundations. Useless from the moment when the community, now rich in workers, has only to be completed by the appearance of the two sexes, the tiny chambers have been pulled down; and their paper, once more reduced to pulp, has been used for the construction 


\section{The Mason-Wasps}

of the large cells, which form the cradles of the sexed grubs. With the additional material brought from without, the demolished cells have served for building new and bigger cells; they have also perhaps provided the wherewithal for a few more scales to the outer wrapper. Sparing of her time, the Wasp does not trouble to exploit distant sources when she has available materials in the house. She knows as well as we do how to make old things into new.

In a complete nest the total number of cells amounts to thousands. Here, for example, are the statistics of one of my specimens. The combs are numbered in the order of seniority: the oldest and therefore the topmost in the stack is no. I; the most recent and therefore the undermost is no. 10.

\begin{tabular}{ccc}
$\begin{array}{c}\text { Combs, in their } \\
\text { order from top } \\
\text { to bottom }\end{array}$ & $\begin{array}{c}\text { Diameter, } \\
\text { in } \\
\text { inches }\end{array}$ & $\begin{array}{c}\text { Number } \\
\text { of } \\
\text { cells }\end{array}$ \\
\hline 1 & 3.94 & 300 \\
2 & 6.28 & 600 \\
3 & 7.87 & 2,000 \\
4 & 9.45 & 2,200 \\
5 & 9.84 & 2,300 \\
6 & 10.23 & 1,300 \\
7 & 9.45 & 1,200 \\
8 & 9.06 & 1,000 \\
9 & 7.87 & 700 \\
10 & 5.12 & 300 \\
& & Total........ 11,900 cells.
\end{tabular}




\section{The Common Wasp}

Obviously the figures in this table must be regarded as approximate. The number of cells varies greatly in different nests and cannot be calculated very accurately. The counting is correct, in the case of each comb, to a hundred or so. Despite the elasticity of these figures, my result agrees very well with that obtained by Réaumur, who, in a nest of fifteen combs, counted sixteen thousand cells. The master adds:

"With only ten thousand cells, as there is perhaps not a cell which does not, on an average, serve to rear three larvæ, a Wasps'nest produces over thirty thousand Wasps a year."

Thirty thousand, say the statistics. What becomes of this multitude when the bad weather arrives? I shall find out. We are now in December; there are occasional frosts, though they are not yet very serious. I know of a nest. I owe it to the man who provides me with Moles, a worthy fellow who, for a few halfpence, makes good the poverty of my vegetable-beds with his own produce. Despite the inconvenience which the proximity caused him, he has preserved the nest for me in his garden, among the 


\section{The Mason-Wasps}

cauliflowers. I can visit it at any moment that I consider opportune.

The moment has come. Preliminary asphyxiation with petrol is no longer necessary: the cold weather will have calmed the fierce ardour of the inmates. The torpid insects will be pacific enough: with a little caution I shall be able to molest them with impunity. Early in the morning, then, the investingtrench is dug with the spade, amid the grass white with hoar-frost. The work proceeds satisfactorily. Not a Wasp stirs. Here is the nest facing us, hanging from the roof of the cavern.

At the bottom of the crypt, rounded like a basin, lie the dead and dying; I could pick them up by the handful. It looks as though the Wasps, when they feel their strength fail them, leave their dwelling and allow themselves to fall into the catacombs of the burrow. It may even be the duty of the ablebodied ones to cast the dead out of the nest. The paper tabernacle must not be defiled by corpses.

Dead Wasps likewise abound in the open air, on the threshold of the crypt. Did they come to die there of their own accord? Or did the survivors, as a hygienic measure, carry them out of doors? I incline to the 260 


\section{The Common Wasp}

idea of the summary funeral. The dying insect, still kicking, is seized by one leg and dragged to the Gemonix. The night cold will kill it outright. These brutal obsequies tally with other instances of savagery, to which we shall return.

In this double cemetery, inside and outside the burrow, the three classes of the population are represented promiscuously. The neuters are the most numerous; next come the males. That these should disappear is quite natural; their part is played. But the future mothers, the femals with flanks rich in eggs, these also perish. Fortunately the Wasps'-nest is not yet entirely deserted. Through a rent I can see a swarm amply sufficient for my plans. We will take the nest away with us and arrange matters for an observation which will last some time and which can be conducted leisurely at home.

The nest will be more convenient to watch if dismembered. Cutting the connecting pillars, I separate the shelves of combs and stack them afresh, giving them a wide fragment of the wrapper as a roof. The Wasps are then re-established in their dwelling, but in limited numbers, to avoid the confusion of a crowd. I keep the more able-bodied and reject the others. The females, the chief 26I 


\section{The Mason-Wasps}

object of my examination, are not far from a hundred strong. Peaceable now and halfnumbed, the population of the nest may safely be subjected to this sifting and shifting. Tweezers are all that $I$ need. The whole nest, installed in a large earthen pan, is covered with a wire-gauze dome. We have only to follow events day by day.

Two factors of decay seem to play a leading part when the Wasps'-nest is depopulated on the advent of the bad weather: hunger and cold. In the winter there is no more provender, no more sweet fruit, the Wasps' principal food. Lastly, notwithstanding their underground shelter, the frost puts an end to the starved creatures. Is this really what happens? We shall see.

The pan containing the Wasps is in my study, where a fire is lit daily in winter, partly for my benefit and partly for that of my insects. It never freezes there; and the sun shines into the room for the greater part of the day. In this mild retreat the risks of depopulation by cold are eliminated. Nor is there any fear of famine. Under the wire cover is a saucer filled with honey; grapepips, furnished by my last bunches kept on the straw, vary the diet. With such provisions as these, if any deaths occur among 262 


\section{The Common Wasp}

the swarm, starvation will not be responsible.

Matters being thus arranged, all goes fairly well in the beginning. After hiding between the combs at night, the Wasps come out when the sun shines on the wire cover. They emerge into the light and stand in it, pressed closely one against the other. Presently they become more animated: they climb to the wire roof, move idly to and fro, descend and quench their appetite at the pool of honey or at the grape-pips. The neuters take to flight, wheel round, cluster on the trelliswork; the bravely-horned males curl their antennæ with quite a sprightly air; the heavier females take no part in these diversions.

A week goes by. The visits to the refectory, though brief, seem to speak of a certain well-being; nevertheless, without apparent cause, mortality now makes a sudden appearance. A neuter is resting in the sun, motionless, on the side of a comb. There is nothing about it to denote ill-health. Suddenly it drops down, falls on its back, moves its abdomen for a moment, kicks its legs about and all is over: it is dead.

As for the females, they too give me cause for alarm. I surprise one as she is crawling out of the nest. Lying on her back, she 263 


\section{The Mason-Wasps}

stretches her limbs, twitches her abdomen and, after a few convulsions, lies absolutely still. I believe her dead. She is nothing of the sort. After a sun-bath, a sovran cordial, she recovers her legs again and goes back to the stack of combs. Yet the resuscitated Wasp is not saved. During the afternoon she is seized with a second fit, which this time leaves her really lifeless, with her legs in the air.

Death, if it be only the death of a Wasp, is always a solemn thing, worthy of our meditation. Day by day, with a curiosity not devoid of emotion, I watch the end of my insects. One detail especially strikes me: the neuters succumb suddenly. They come to the surface, slip down, fall on their backs and rise no more, as though they were struck by lightning. They have had their day; they are slain by age, that inexorable toxin. Even so does a piece of clockwork become inert when its mainspring has unwound its last spiral.

But the females, the last-born of the community, far from being overcome by decrepitude, are, on the contrary, just entering upon life. They have the vigour of youth; and so, when the winter sickness seizes them, they are capable of a certain resistance, 


\section{The Common Wasp}

whereas the old workers perish suddenly. In the same way, the males, so long as their part is not played out, resist the cold fairly well. My cage contains a few, always nimble and alert. I see them making advances to their companions, without greatly insisting. They are repulsed with a friendly push of the leg. The time is past for the raptures of the pairing. Those lingerers, have let the right moment slip; they will die useless.

The females whose end is near are easily distinguished from the others by the disorder of their appearance. Their backs are dusty. Those who are hale and hearty, once they have taken their meal on the brim of the saucer of honey, settle in the sun and dust themselves without ceasing. There is an incessant brushing of the wings and abdomen, with gentle, sensitive extensions of the hindlegs; the fore-legs repeatedly stroke the head and the thorax. Thus the black-and-yellow costume is kept perfectly glossy. Those who are ailing, careless of cleanliness, stand motionless in the sun or wander languidly about. They no longer brush their clothes.

This indifference to dress is a bad sign. Two or three days later, in fact, the dusty female leaves the nest for the last time and 


\section{The Mason-Wasps}

goes on the roof, to enjoy yet a little of the sunlight; then, her nerveless claws relinquishing their hold, she slides quietly to the ground and does not get up again. She declines to die in her beloved paper home, where the code of the Wasps ordains absolute cleanliness.

If the neuters, those fierce hygienists, were still there, they would seize the helpless creature and drag her outside. Themselves the first victims of the winter evil, they are lacking; and the dying Wasp proceeds to perform her own funeral rites by dropping herself into the charnel-pit at the bottom of the cavern. For reasons of health, an indispensable condition with such a multitude, these stoics refuse to die in the actual house, among the combs. The last survivors retain this repugnance to the very end. For them it is a law which never falls into disuse, however greatly reduced the population may be. No corpse can be allowed to remain in the babies' dormitory.

My cage becomes emptier day by day, notwithstanding the mild temperature of the room, notwithstanding the saucer of honey at which the able-bodied come to sip. At Christmas I have only a dozen females left. 


\section{The Common Wasp}

On the 6th of January, with snow out of doors, the last of them perishes.

Whence arises this mortality, which mows down the whole of my Wasps? My attentions have preserved them from the calamities which at first sight might appear to cause their death under the usual conditions. Fed upon honey and grapes, they have not suffered from famine: warmed by the heat of my fire, they have not suffered from cold; cheered almost daily by the sun's rays and living in their own nest, they have not suffered from home-sickness. Then what have they died of?

I can understand the disappearance of the males. These are henceforth useless; the pairing has taken place and the eggs are fertile. I can less easily explain the death of the neuters, who, on the return of spring, would be of such great assistance when new colonies are founded. What I do not understand at all is the death of the females. I had nearly a hundred; and not one has survived the first few days of the new year. Having left their nymphal cells in October and November, they still possessed the vigorous attributes of youth; they represented the future; yet this sacred quality of prospective 


\section{The Mason-Wasps}

motherhood has not saved them. Even as the feeble males retired from business, even as the workers exhausted by labour, they too have succumbed.

We must not blame their internment under wire for their death. The same thing happens in the open country. The various nests inspected at the end of December all reveal a similar mortality. The females die almost as rapidly as the rest of the population.

This was to be expected. The number of females who are daughters of the same nest is unknown to me. However, the profusion of their dead bodies in the charnel-pit of the colony tells me that they must be counted by the hundred, perhaps by the thousand. One female is enough to found a city of thirty thousand inhabitants. If all were to prosper, what a scourge! The Wasps would tyrannize over the country-side.

The order of things demands that the vast majority shall die, killed not by an accidental epidemic and the inclemency of the season, but by an inevitable destiny, which performs its work of destruction with the same energy as that which it displays in the task of procreation. One question thereupon arises: since a single female, preserved in 


\section{The Common Wasp}

one way or another, is enough to maintain the species, why does a Wasps'-nest contain so many aspirant mothers? Why a multitude in place of one? Why so many victims? A perturbing problem, in which our intelligence fails to see its way. 


\section{CHAPTER XI}

THE COMMON WASP (continued)

F the calamities that befall the Wasp when winter arrives, the worst remains to be told. Foreseeing the approach of failing power, the neuters, hitherto the tenderest of nurses, become savage exterminators:

"Let us leave no orphans," they say to themselves; " no one would tend them after we are gone. Let us kill everything, belated eggs and larvæ alike. A violent end is preferable to slow death by starvation."

A massacre of the innocents ensues. Seized by the scruff of the neck and brutally extirpated from their cells, the larvæ are dragged out of the nest and thrown into the vat at the bottom of the crypt; the eggs, those delicate morsels, are ripped open and devoured. Will it be possible for me to witness this tragic end of the city, not in the fulness of its horror - that ambition is too far beyond my resources - but at least in some of its scenes? Let us try.

In October, I place under cover a few fragments of a nest which have been saved 


\section{The Common Wasp}

from asphyxiation. By moderating the dose of petrol I can easily obtain a number of Wasps afflicted merely with a passing torpor, which enables me to collect them without being stung and which disappears as the sufferers are exposed to the air. Note also that, even with a fairly strong dose of petrol, capable of killing all the adults, the larvæ do not succumb. Mere digesting bellies, they hold out when the more delicately-organized adults perish. Safe from misadventure, I have been able in this way to establish in a cage a portion of a nest rich in eggs and larvæ, with some hundred neuters as attendants.

To facilitate my inspection, I separate the combs and place them side by side, with the openings of the cells turned upwards. This arrangement, which reverses the normal, does not appear to annoy my captives, who, soon recovering from their disturbance, set to work as if nothing unusual had occurred. In case they should wish to build, I give them a slip of soft wood to draw upon. Lastly, I feed them with honey, poured into a pool on a strip of paper and renewed daily. The underground cavern is represented by a large earthen pan surmounted by a wire-gauze cover. A cardboard dome, placed over the 


\section{The Mason-Wasps}

cover or removed at will, provides alternately the obscurity demanded by the Wasps' labours and the light needed for my observations.

The work is continued from one day to another. The Wasps attend at the same time to the larvæ and to the house. The builders begin to erect a wall round the most thicklycolonized combs. Do they intend to repair the disaster and build a new envelope, which will replace the vanished enclosing wall? The progress of the operation seems to tell us no. They are simply continuing the work which my terrible flask and my spade have interrupted. Over an area embracing hardly a third of the comb, they erect an arched roof of paper scales which would have been joined to the envelope of the nest had it been intact. They are not beginning again; they are continuing.

In any case, the sort of tent thus obtained shelters but a small part of the disk of cells. This is not for lack of materials. To begin with, there is the slip of wood, providing, in my opinion, an excellent supply of fibrous scraps. But the Wasps do not touch it. Perhaps I have chosen the wrong sort of piece, being but ill-versed in the secrets of Vespian paper-making. 


\section{The Common Wasp}

To these raw materials, which are troublesome to work, they prefer the old cells, now fallen into disuse. In these the felted fibres are ready prepared and have only to be reduced to pulp again. With a slight expenditure of saliva and a little grinding in the mandibles, it yields a product of the highest quality. The uninhabited cells, therefore, are demolished by degrees, nibbled and razed to their foundations. Out of the ruins a sort of canopy is built. New cells would be constructed in the same way if they were needed. This confirms what the upper stories with demolished cells made us foresee: the Wasps build new cells with old.

The feeding of the grubs deserves examination even more than this roofing-work. One would never weary of the spectacle of these rough fighters converted into tender nurses. The barracks are turned into a crèche. What care, what vigilance in the rearing of the grubs! Let us watch one of the busy Wasps. Her crop swollen with honey, she halts in front of a cell; almost pensively she bends her head into the orifice; she questions the recluse with the tip of her antenna. The larva wakes and gapes at her, like the fledgeling when the mother-bird returns to the nest with food. 


\section{The Mason-Wasps.}

For a moment, the awakened larva swings its head to and fro: it is blind and is trying to feel the pap brought to it. The two mouths meet; a drop of syrup passes from the nurse's mouth to the nurseling's. That is enough for the moment. Now for the next. The Wasp moves on, to continue her duties elsewhere.

The larva, on its side, licks the base of its neck for a few seconds. There is here, at the moment when the grub is being served with food, a sort of projecting bib, a temporary dewlap' which forms a porringer and receives what trickles from the lips. After swallowing the bulk of the ration, the larva finishes its meal by gathering up the crumbs which have fallen on its bib. Then the swelling disappears; and the grub, withdrawing a little way into its cell, resumes its sweet slumbers.

The better to watch this curious fashion of eating, I happen by good luck to have a few powerful Hornet-larvæ. I slip them singly into paper sheaths, which will represent their natal cells. Thus swaddled, my fat babies lend themselves excellently to observation when I myself distribute their rations.

In my young days, we had a trick of tap- 


\section{The Common Wasp}

ping with our finger the incipient tail of the Sparrow whom we were rearing. The pupil at once yawned, ready to receive his food. I like to imagine that this system of birdtraining is still in vogue. But there is no need of these stimulating preliminaries to arouse the appetite of the Hornet's offspring. They yawn of their own accord at the least touch that I give to their cell. The lucky creatures have ever-ready stomachs.

Taking a piece of straw with a drop of honey hanging from it, I place the delicious ration between the grub's mandibles. There is too much for a single mouthful. But the breast swells into a dewlap which catches the surplus. Here the grub will take a few more sips, at its leisure, after swallowing the spoonful which it received direct. When there is no more left, when the pectoral platter is licked clean, the swelling disappears and the larva resumes its immobility. Thanks to this short-lived swelling, suddenly flung out and as suddenly withdrawn, the diner has its table spread beneath its chin; without assistance from others, it finishes its meal alone.

When fed in my cage, the Wasps' grubs have their heads up; and what escapes their lips collects upon the dewlap. When fed 


\section{The Mason-Wasps}

normally, in the Wasps'-nest, they have their heads down. In this position is the protuberance on the breast of any service? I cannot doubt it.

By slightly bending its head, the larva can always deposit on its projecting bib a portion of the copious mouthful, which adheres to it by reason of its stickiness. Further, there is nothing to tell us that the nurse does not herself deposit the surplus of her helping on this spot. Whether it be above or below the mouth, right way up or upside down, the pectoral porringer fulfils its office because of the sticky nature of the food. It is a temporary saucer which shortens the work of serving and enables the grub to feed in a more or less leisurely fashion and without too much gluttony.

In the cage my Wasps are fed with honey, which they disgorge for the larvæ, once their crops are full. Both nurses and nurselings seem to thrive on this diet. Nevertheless, I know that the usual food is game. I have described elsewhere the hunting of the Eristalis by the Common Wasp and of the Hive-bee by the Hornet. ${ }^{1}$ The moment she is caught, the big Fly in particular is dis-

1 Cf. The Hunting Wasps: chap. vii.-Translator's Note. 


\section{The Common Wasp}

membered; the head, wings, legs and belly, those meagre portions, are cut off with snips of the shears. There remains the breast, which is rich in muscular tissues. This is the booty which, minced small upon the spot and reduced to a pill, is carried to the nest as a feast for the larvæ.

To honey, therefore, let us add game. I slip a few Eristales under the wire dome. At first the newcomers are not molested. The turbulent Flies, fluttering, buzzing, butting their heads against the wire-gauze, create no sensation in the cage. The inmates take no notice of them. If one of them pass too near to a Wasp, the Wasp just raises her head, as though in threat. That is quite enough; the Fly decamps.

Matters become more serious around the strip of paper covered with honey. The refectory is assiduously frequented by the Wasps. If the Eristalis, watching jealously from afar, venture to approach, one of the banqueters separates from the group, rushes headlong at the daring one, catches her by the leg and sends her to the right-about. The encounter is not really grave except when the Fly commits the imprudence of alighting on a comb. Then the Wasps fling themselves upon the hapless intruder, roll her over 


\section{The Mason-Wasps}

and over, cuff her and drub her and drag her outside crippled or, as often as not, dead. The body is disdainfully rejected.

I renew my attempts in vain; I cannot reproduce the scenes which I used to witness on the aster-blossoms: the capture of the Eristalis and her reduction to mincemeat for the larvæ. Perhaps this strong animal fare is distributed only on certain occasions which are not realized in my cage; or perhaps and I more incline to favour this idea honey is judged to be better than meat. My prisoners have plenty of it, served up fresh daily. The nurselings thrive on this diet; and the salmis of Flies is rejected in consequence.

But in the open country, in the late autumn, fruit is scarce; and, in the absence of sweet pulp, we fall back upon game. Minced Eristalis may well be only a secondary resource of the Wasps. Their refusal of my offerings seems to prove it.

We will now consider the Polistes. Her absolutely Wasp-like shape and costume take nobody in for a moment. She is at once recognized and is mobbed as the Eristalis was, if she dare approach the honey whereat the Wasps are sipping. On neither side, however, is there any attempt at stinging: these 278 


\section{The Common Wasp}

table-quarrels are not worth the drawing of a dagger. Realizing that she is the weaker and that she is not at home, the Polistes retires. She will come back again and so persistently that the diners end by allowing her to take her seat beside them, a concession very rarely made to the Eristalis. This toleration does not last long: if the Polistes but venture on the combs, this alone arouses a terrible anger and brings about the death of the intruder. No, it is not a good thing to enter the Wasps'-nest, even when the stranger wears the same uniform, pursues the same industry and is almost a fellow-member of the corporation.

Let us now try the Bumble-bee. Here is a male, quite a small one, clad in russet. The poor little beggar is threatened and even hustled, but no more, each time that he passes near a Wasp. Now, however, the scatterbrain comes tumbling from the top of the trelliswork and drops on a comb, in the midst of the busy nurses. I am all eyes as I follow the tragedy. One of them seizes the Bumble-bee by the neck and stabs him in the breast. A few convulsions of the legs follow; and the Bumble-bee is dead. Two other Wasps come to the murderess' assistance and help her drag the deceased out- 


\section{The Mason-Wasps}

side. Once more, I remark, it is not a good thing to enter the Wasps' nest, even by accident and without any bad intention.

Here are a few more examples of the savage welcome given to strangers. I do not select my victims; I use them as they happen to come. A rose-tree outside my door supplies me with Hylotoma-larvæ, ${ }^{1}$ larvæ shaped like caterpillars. I place one in the midst of the Wasps, who are busy with their cells. Great surprise on the part of the workers confronted by this sort of green dragon, spotted with black! They come near; they withdraw; they again come near. One snaps at it boldly, inflicting a bleeding wound. Others follow her example, bite and endeavour to haul away the wounded creature. The dragon resists, holding now by its fore-legs and now by its hind-legs. The burden is not too heavy, but the insect struggles indefatigably, anchored by its hooks. However, after numerous attempts, the grub, enfeebled by its wounds, is torn from the comb and dragged, all bleeding, to the refuse-pit. It has taken a couple of hours to dislodge it.

With the Hylotoma-larva the Wasps did

${ }^{1}$ Hylotoma rosa, the Saw-fly of the Rose. Cf. Chapter XII. of the present volume.-Translator's Note. 


\section{The Common Wasp}

not use the sting, which would have so promptly put an end to all resistance. Perhaps they deemed the wretched grub unworthy of ceremonial death. The expeditious method of the poisoned dagger appears to be reserved for great occasions. Thus perished the Bumble-bee and the Polistes; thus will perish a larva of the Scalary Saperda, ${ }^{1}$ an imposing grub extracted that moment from under the bark of a dead cherry-tree.

I fling it on one of the combs. The Wasps are greatly excited by the fall of the monster, which goes into vigorous contortions. Five or six at a time assail it, first quickly biting into it and then pricking it with their stings. In a couple of minutes the grub, stabbed through and through, no longer stirs. As for carrying the huge dead body out of the nest, that is another matter; it is too heavy, much too heavy. What will the Wasps do? Unable to shift the grub, they eat it where it lies, or rather they drain it dry, drinking its blood. An hour later, flaccid now and greatly diminished in weight, the cumbrous corpse is dragged outside the walls.

1 A Beetle whose larva lives in the shoots of cherryand walnut-trees, as well as in those of alder and elm. Cf. Chapter XII. of the present volume.-Translator's Note. 


\section{The Mason-Wasps}

The rest of my notes would only repeat the same results. If he keep a certain distance, the stranger is tolerated, no matter what his race, his costume or his habits. If he pass near a Wasp, a threat warns him and puts him to flight. If he go to the pool of honey, when the refectory is already occupied by the Wasps, it seldom happens that the daring intruder is not molested and driven from the banquet. So far, blows of no great gravity suffice. But, if he have the misfortune to enter the actual nest, he comes to a bad end, pierced by the WVasps' stings or at least disembowelled by the fangs of their mandibles. His corpse goes to join the other refuse in the basement.

Protected with this fierce vigilance against the invasion of all intruders and deliciously spoon-fed on honey, on that excellent honey which causes Fly-meat to be forgotten, the larva prosper greatly in my breeding-cage, though of course not all. In the Wasps'nest, as everywhere, there are weaklings who are cut down before their time.

I see these puny sufferers refuse their food and slowly pine away. The nurses perceive it even more clearly. They bend their heads over the sorely-tried grub, they sound it with their antenna, they pronounce it incurable. 


\section{The Common Wasp}

Then the creature at point of death, often of a sickly brown, is torn ruthlessly from its cell and dragged outside the nest. In the brutal commonwealth of the Wasps, the invalid is merely a clout, to be got rid of as quickly as possible, for fear of contagion.

Woe to the sick among these rude professors of hygiene! Any and every cripple is expelled and thrown to the maggot waiting to eat him in the catacombs below. Should the experimenter intervene, matters take an even more atrocious turn. I remove from their cells a few larvæ and nymphs in excellent heath and place them on the surface of the combs. Once outside the cells, where the nymphs were maturing under a silken cupola, while the larvæ were being spoonfed with the utmost tenderness, the delicate creatures are mere hateful obstacles and useless encumbrances. Ferociously the workers tug at them, disembowel them and even eat a little of them. After this cannibal repast, the victims are carted outside the nest. Incapable of reentering their cradles, even with assistance, larvæ and nymphs, stripped bare, perish, slain by their nurses.

In the cage, however, the grubs generally display a well-fed, glossy skin, a certificate of good health. But see what happens on the 283 


\section{The Mason-Wasps}

advent of the first cold nights of November. The building proceeds with diminished enthusiasm; the visits to the pool of honey are less assiduous. Household duties are relaxed. Grubs gaping with hunger receive tardy relief, or are even neglected. Profound uneasiness seizes upon the nurses. Their former devotion is succeeded by indifference, which soon turns to aversion. What is the use of continuing attentions which presently will become impossible? In view of the imminent famine, our beloved nurselings must die a tragic death.

The neuters, in fact, grab the late-born larvæ, these to-day, those to-morrow, sooner or later the rest, and root them out of their cells with the same violence which they would employ against a stranger or a lifeless body; they tug at them, savagely rend them; and all this poor flesh is sent down to the pit.

Before much longer, the neuters themselves, the executioners, are languidly dragging what remains of their lives. At length they also succumb, killed by the weather. November is not yet past; and nothing is left alive in my cage. The final massacre of the tardy larvæ must take place underground in more or less the same manner, but on a larger scale. 


\section{The Common Wasp}

Day after day the catacombs of the Wasps'-nest receive the dead and dying hurled down from above, sickly larvæ and such Wasps as have been injured by accident. Rare in the prosperous season, these falls into the charnel-heap become increasingly frequent as winter approaches. When the late-born grubs are being exterminated and above all at the moment of the final catastrophe, when the adults, males, females and neuters, are dying in their thousands, the manna descends in a copious downfall daily.

The host of devourers has hastened up, receiving only a little at first, but foreseeing great junketings in the future. By the end of November, the bottom of the crypt is a swarming hostelry, dominated numerically by the grubs of certain Flies, those undertakers of the Wasps'-nests. I gather great numbers of the larvæ of the Volucella, who deserves a chapter to herself, by reason of her fame. I find here, poking its tapering head into the bellies of the corpses, a naked, white, pointed maggot, smaller than that of the Luciliæ. It works promiscuously with a second, even smaller grub, brown and clad in a prickly smock. I come upon a dwarf

1 Or Greenbottles. Cf. The Life of the Fly: chap. ix. - Translator's Note. 


\section{The Mason-Wasps}

which, looping and unlooping, wriggles about like the Cheese-mites.

All of them are dissecting, dismembering and disembowelling with so much zeal that, when February arrives, they have not yet had time to shrink into pupæ. It is so pleasant here, sheltered against the inclemencies of the weather, in the snug basement, with provisions in abundance! Why hurry? These smug eaters expect to consume the heap of victuals before hardening their skin into a barrel. They linger so long over their banquet that I forget to secure them for my rearing-phials; and I can say no more about their history.

In the charnel-houses of Moles and Snakes in my aerial retting-vats, ${ }^{1}$ I used to note, from time to time, the arrival of the largest of our Staphylini, ${ }^{2}$ S. maxillosus, who, in passing, would make a brief stay under the putrid mass and then proceed to pursue her business elsewhere. The Wasps' charnel-house similarly has short-winged Beetles among its habitual visitors. I often come upon Quedius fulgidas, FAB., there, the one with the red wing-cases. But this time it is not a temporary hostelry; it is a family es-

1 Cf. The Life of the Fly: chap. ix.-Translator's Note.

2 Rove-beetles.-Translator's Note. 


\section{The Common Wasp}

tablishment, for the adult Staphylinus is accompanied by her larva. I also find Woodlice and Millipedes, of the genus Polydesma, both inferior trenchermen, feeding probably on the humours oozing from the dead.

Let us also mention one of the outstanding insect-eaters, the tiniest of our mammals, the Shrew, who is smaller than the Common Mouse. At the time of the final catastrophe, when sickness has calmed the aggressive fury of the Wasps, the visitor with the pointed muzzle steals into the nest: Exploited by a pair of Shrew-mice, the dying crowd is soon reduced to a heap of remnants which the maggots end by clearing out.

The ruins themselves will perish. A caterpillar that develops later into a mean-looking, whitish Moth; a Cryptophagus, a tiny reddish Beetle; and a larva of one of the Dermestes ${ }^{1}$ (Attagenus pellio), clad in scaly gold velvet, gnaw the floors of the stages and crumble the whole dwelling. A few pinches of dust, a few shreds of brown paper are all that remains, by the return of spring, of the Vespian city and its thirty thousand inhabitants.

1 Bacon-beetles.-Translator's Note. 


\section{CHAPTER XII}

THE VOLUCELLA

UNDERNEATH the brown-paper manorhouse, let us once more say, the ground is channelled into a sort of drain for the refuse of the nest. Here are shot the dead or weakly larvæ which a continual inspection roots out from the cells to make room for fresh occupants; here, at the time of the autumn massacre, are flung the backward grubs; here, lastly, lies a good part of the crowd killed by the first touch of winter. During the rack and ruin of November and December, this sewer becomes crammed with animal matter.

Such riches will not remain unemployed. The world's great law which says that nothing edible shall be wasted provides for the consumption of a mere ball of hair disgorged by the Owl. How shall it be with the vast stores of a ruined Wasps'-nest! If they have not come yet, the consumers whose task it is to salve this abundant wreckage for nature's markets, they will not tarry in coming and waiting for the manna that will soon 288 


\section{The Volucella}

descend from above. That public granary, lavishly stocked by death, will become a busy factory of fresh life. Who are the guests summoned to the banquet?

If the Wasps flew away, carrying the dead or sickly grubs with them, and dropped them on the ground round about their home, those banqueters would be, first and foremost, the insect-eating birds, the Warblers, all of whom are lovers of small game. In this connection, we will allow ourselves a brief digression.

Everybody knows with what jealous intolerance the Nightingales occupy each his own cantonment. Neighbourly intercourse among them is tabooed. The males frequently exchange defiant couplets at a distance; but, should the challenged party draw near, the challenger makes him clear off. Now, not far from my house, in a scanty clump of holly-oaks which would barely give a wood-cutter the wherewithal to make a dozen faggots, I used, all through the spring, to hear such full-throated warbling of Nightingales that the songs of these virtuosi, all giving voice at once and with no attempt at order, degenerated into a deafening hubbub.

Why did those passionate devotees of solitude come and settle in such large numbers 


\section{The Mason-Wasps}

at a spot where custom decrees that there is just room for one household only? What reasons have turned the recluse into a congregation? I asked the owner of the spinney about the matter.

"It's like that every year," he said. "The clump is overrun by Nightingales."

"And the reason?"

"The reason is that there is a stand of hives close by, behind that wall."

I looked at the man in amazement, unable to understand what connection there could be between a stand of hives and the thronging Nightingales.

"Why, yes," he added, "there are a lot of Nightingales because there are a lot of Bees."

Another questioning look from my side. I did not yet understand. The explanation came :

"The Bees," he said, "throw out their dead grubs. The front of the stand is strewn with them in the mornings; and the Nightingales come and collect them for themselves and their families. They are very fond of them."

This time I had solved the puzzle. Delicious food, abundant and fresh each day, had brought the songsters together. Con- 


\section{The Volucella}

trary to their habit, numbers of Nightingales are living on friendly terms in a cluster of bushes, in order to be near the hives and to have a larger share in the morning distribution of plump dainties.

In the same way, the Nightingale and his gastronomical rivals would haunt the neighbourhood of the Wasps'-nests, if the dead grubs were cast out on the surface of the soil; but these delicacies fall inside the burrow and no little bird would dare to enter the murky cave, even if the entrance were not too small to admit it. Other consumers are needed here, small in size and great in daring; the Fly is called for and her maggot, the king of the departed. What the Greenbottles, Bluebottles and Flesh-flies ${ }^{1}$ do in the open air, at the expense of every kind of corpse, other Flies, narrowing their province, do underground at the Wasps' expense.

Let us turn our attention, in September, to the wrapper of a Wasps'-nest. On the outer surface and there alone, this wrapper is strewn with a multitude of big, white, oval dots, firmly fixed to the brown paper and measuring roughly one-tenth of an inch long by one-sixteenth of an inch wide. Flat

1 Cf. The Life of the Fly: chaps. ix., x. and xiv. to xvi. - Translator's Note. 


\section{The Mason-Wasps}

below, convex above and of a lustrous white, these dots resemble very neat drops from a tallow candle. Lastly, their backs are streaked with faint transversal lines, an elegant detail perceptible only with the lens. These curious objects are scattered all over the surface of the wrapper, sometimes at a distance from one another, sometimes gathered into more or less dense groups. They are the eggs of the Volucella, or Bumble-bee Fly ( $V$. zonaria, LIN).

Also stuck to the brown paper of the outer envelope and mixed up with the Volucella's are a large number of other eggs, chalkwhite, spear-shaped and ridged lengthwise with seven or eight thin ribs, after the manner of the seeds of certain Umbelliferæ. The finishing touch to their delicate beauty is the fine stippling all over the surface. They are smaller by half than the others. I have seen grubs come out of them which might easily be the earliest stage of some pointed maggots which I have already noticed in the burrows. My attempts to rear them failed; and I am not able to say to which Fly these eggs belong. Enough for us to note the nameless one in passing. There are plenty of others, which we must make up our minds to leave unlabelled, in view of the 


\section{The Volucella}

jumbled crowd of feasters in the ruined Wasps'-nest. We will concern ourselves only with the most remarkable, in the front rank of which stands the Volucella.

She is a gorgeous and powerful Fly; and her costume, with its brown and yellow bands, shows a vague resemblance to that of the Wasps. Our fashionable theorists have availed themselves of this brown and yellow to cite the Volucella as a striking instance of protective mimicry. Obliged, if not on her own behalf, at least on that of her family, to introduce herself as a parasite into the Wasp's home, she resorts, they tell us, to trickery and craftily dons her victim's livery. Once inside the Wasps'-nest, she is taken for one of the inhabitants and attends quietly to her business.

The simplicity of the Wasp, duped by a very clumsy imitation of her garb, and the depravity of the Fly, concealing her identity under a counterfeit presentment, exceed the limits of my credulity. The Wasp is not so silly nor the Volucella so clever as we are assured. If the latter really meant to deceive the Wasp by her appearance, we must admit that her disguise is none too successful. Yellow sashes round the abdomen do not make a Wasp. It would need more than 


\section{The Mason-Wasps}

that and, above all, a slender figure and a nimble carriage; and the Volucella is thickset and corpulent and sedate in her movements. Never will the Wasp take that unwieldly insect for one of her own kind. The difference is too great.

Poor Volucella, mimesis has not taught you enough! You ought - this is the essential point - to have adopted a Wasp's shape and you forgot to do so; you remained a fat Fly, far too easily recognized. Nevertheless, you penetrate into the terrible cavern; you are able to stay there for a long time, without danger, as the eggs profusely strewn on the wrapper of the Wasps'-nest show. How do you set about it?

Let us, first of all, remember that the Volucella does not enter the enclosure in which the combs are stacked: she keeps to the outer surface of the paper rampart and there lays her eggs. Let us, on the other hand, recall the Polistes placed in the company of the Wasps in my breeding-cage. Here of a surety is one who need not have recourse to mimicry to find acceptance. She belongs to the guild, she is a Wasp herself. Any of us that had not the trained eye of the entomologist would confuse the two species. Well, this stranger, so long as she does not 


\section{The Volucella}

become too importunate, is quite readily tolerated by the caged Wasps. None seeks to pick a quarrel with her. She is even admitted to the table, the strip of paper smeared with honey. But she is doomed if she inadvertently sets foot upon the combs. Her costume, her shape, her size, which tally almost exactly with the costume, shape and size of the Wasp, do not save her from her fate. She is at once recognized as a stranger and attacked and slaughtered with the same vigour as the larva of the Hylotoma and the Saperda, neither of which bears any outward resemblance to the Wasps.

If identity of shape and costume do not save the Polistes, how will the Volucella fare, with her clumsy imitation? The Wasp's eye, which is able to discern the dissimilar in the like, will refuse to be caught. The moment she is recognized, the stranger is killed on the spot. As to that there is not the shadow of a doubt.

In the absence of Volucellæ at the moment of experimenting, I employ another Fly, Milesia fulminans, who, thanks to her slim figure and her handsome yellow bands, presents a much more striking likeness to the Wasp than does the fat $V$. zonaria. De- 


\section{The Mason-Wasps}

spite this resemblance, if she rashly venture on the combs, she is stabbed and slain. Her yellow sashes, her slender abdomen deceive nobody. The stranger is recognized behind the features of a double.

My experiments under wire-gauze, which vary according to the captures which I happen to make, all lead me to this conclusion: so long as there is mere propinquity, even around the honey, the other prisoners are tolerated fairly well; but, if they touch the cells, they are assaulted and often killed, without distinction of shape or costume. The grubs' dormitory is the sanctum sanctorum which no outsider must enter under pain of death.

With these caged captives I experiment by daylight, whereas the free Wasps work in the absolute darkness of their crypt. Where light is absent, colour goes for nothing. Once, therefore, that she has entered the cavern, the Volucella derives no benefit from her yellow bands, which are supposed to be her safeguard. Whether garbed as she is or otherwise, it is easy for her to effect her purpose in the dark, on condition that she avoid the tumultuous interior of the Wasps'-nest. So long as she has the prudence not to hustle the passers-by, she can dab her eggs, 


\section{The Volucella}

without danger, on the paper wall. No one will know of her presence. The dangerous thing is to cross the threshold of the burrow in broad daylight, before the eyes of those who go in and out. At that moment alone, protective mimicry would be convenient. Now does the entrance of the Volucella into the presence of a few Wasps entail such very great risks? The Wasps'-nest in my enclosure, the one which was afterwards to perish under a bell-glass in the sun, gave me the opportunity for prolonged observations, but without any result upon the subject of my immediate concern. The Volucella did not appear. The period for her visits had doubtless passed; for I found plenty of her grubs when the nest was dug up.

Other Flies rewarded me for my assiduity. I saw some - at a respectful distance, I need hardly say - entering the burrow. They were insignificant in size and of a darkgrey colour, not unlike that of the House-fly. They had not a patch of yellow about them and certainly had no claim to protective mimicry. Nevertheless, they went in and out as they pleased, calmly, as though they were at home. So long as there was not too great a number at the door, the Wasps left them alone. When there was anything of a 


\section{The Mason-Wasps}

crowd, the grey visitors waited near the threshold for a less busy moment. No harm came to them.

Inside the establishment, the same peaceful relations prevail. In this respect I have the evidence of my excavations. In the underground charnel-house, so rich in Flygrubs, I find no corpses of adult Flies. If the strangers were slaughtered in passing through the entrance-hall or lower down, they would fall to the bottom of the burrow promiscuously with the other rubbish. Now in this charnel-pit, as I said, there are never any dead Volucellæ, never a Fly of any sort. The incomers, therefore, are respected. Having done their business, they go out unscathed.

This tolerance on the part of the Wasps is surprising. And a suspicion comes to one's mind: can it be that the Volucella and the rest are not what the accepted theories of natural history call them, namely, enemies, grub-killers sacking the Wasps'-nest? We will look into this by examining them when they are hatched. Nothing is easier, in September and October, than to collect the Volucella's eggs in such numbers as we please. They abound on the outer surface of the Wasps'-nest. Moreover, as with the 


\section{The Volucella}

larvæ of the Wasp, it is some time before they are suffocated by the petrol; and the great majority are sure to hatch. I take my scissors, cut the most densely-populated bits from the paper wall of the nest and fill a jar with them. This is the warehouse from which I shall daily, for the best part of the next two months, draw my supply of infant grubs.

The Volucella's egg remains where it is, with its white colouring strongly marked against the grey background of the support. The shell wrinkles and collapses; and the fore-end tears open. From it there issues a pretty little white grub, thin in front, widening slightly in the rear and bristling all over with fleshy papillæ. These papillæ are set, on the creature's sides, like the teeth of a comb; at the rear, they lengthen and spread into a fan; on the back, they are shorter and arranged in four longitudinal rows. The last segment but one carries two short, bright-red breathing-tubes, standing aslant and joined to each other. The forepart, near the pointed mouth, is of a darker, brownish colour. This is the biting- and motor-apparatus, seen through the skin and consisting of two fangs. Taken all round, the grub is a comely little thing, with its 


\section{The Mason-Wasps}

bristling whiteness, which gives it the appearance of a tiny snow-flake. But this elegance does not last long: grown big and strong, the Volucella's grub becomes soiled with sanies, turns russet-brown and crawls about in the guise of a hulking Porcupine.

What becomes of it when it leaves the egg? This my warehousing-jar tells me, partly. Unable to keep its balance on sloping surfaces, it drops to the bottom of the receptacle, where I find it daily, as and when hatched, restlessly wandering. Things must happen likewise at the Wasps'. Incapable of standing on the slant of the paper wall, the new-born grubs slide to the bottom of the underground cavity, which contains, especially at the end of the summer, a plentiful provender of deceased Wasps and dead larvæ removed from the cells and flung outside, all nice and gamy, as proper maggot'sfood should be.

The Volucella's offspring, themselves maggots, notwithstanding their snowy apparel, find in this charnel-house victuals to their liking, incessantly renewed. Their fall from the high walls might well be not accidental but rather a means of reaching, quickly and without searching, the good things down at the bottom of the cavern. Perhaps, also, 


\section{The Volucella}

some of the white grubs, thanks to the holes that make the wrapper resemble a spongy cover, manage to slip inside the Wasps'-nest. Still, most of the Volucella's larvæ, at whatever stage of their development, are in the basement of the burrow, among the carrion remains. The others, those settled in the Wasps' home itself, are comparatively few.

These returns are enough to show us that the grubs of the Volucella do not deserve the bad reputation that has been given them. Satisfied with the spoils of the dead, they do not touch the living; they do not ravage the Wasps'-nest, they disinfect it.

Experiment confirms what we have learnt in the actual nests. Over and over again, I bring Wasp-grubs and Volucella-grubs together in small test-tubes, which are easy to observe. The first are well and strong; I have just taken them from their cells. The others are in various stages, from that of the snow-flake born the same day to that of the sturdy Porcupine.

There is nothing tragic about the encounter. The Flies' grubs roam about the test-tube without touching the live tit-bit. The most that they do is to put their mouths for a moment to the morsel; then they take it away again, not caring for the dish. 


\section{The Mason-Wasps}

They want something different: a wounded, a' dying creature; a corpse dissolving into sanies. Indeed, if I prick the Wasp-grub with a needle, the scornful ones immediately come and sup at the bleeding wound. If I give them a dead larva, brown with putrefaction, the grubs rip it open and feast on its humours. Better still: I can feed them quite satisfactorily with Wasps that have turned putrid under their horny rings; I see them greedily suck the juices of decomposing Cetonia-larvæ; I can keep them thriving with chopped-up butcher's meat, which they know how to liquefy by the method of the common maggot. And these unprejudiced ones, who accept whatever comes their way, provided that it be dead, refuse it when it is alive. Like the true Flies and frank bodysnatchers that they are, they wait, before touching a morsel, for death to do its work.

Inside the Wasps'-nest, robust larvæ are the rule and weaklings the rare exception, because of the assiduous supervision which eliminates anything that is like to die. Here, nevertheless, Volucella-grubs are found, on the combs', among the-busy Wasps. They are not, it is true, so numerous as in the charnel-house below, but still they are pretty frequent. Now what do they 


\section{The Volucella}

do in this abode where there are no corpses? Do they attack the healthy? Their continual visits from cell to cell would at first make one think so; but we shall soon be undeceived if we observe their movements closely; and this is possible with my caged colonies.

I see them fussily crawling on the surface of the combs, swaying their necks from side to side and taking stock of the cells. This one does not suit, nor that one either; the bristly creature passes on, still in quest of something, thrusting its pointed fore-part now here, now there. This time, the cell appears to fulfil the requisite conditions. A larva, glowing with health, opens wide its mouth, believing its nurse to be approaching. It fills the hexagonal chamber with its bulging sides.

The gluttonous visitor bends and slips its slender fore-part, a blade of equisite suppleness, between the wall and the inhabitant, whose slack rotundity yields to the pressure of this animated wedge. It plunges into the cell, leaving no part of itself outside but its wide hind-quarters, with the red dots of the two breathing-tubes.

It remains in this posture for some time, occupied with its work at the bottom of the cell. Meanwhile, the Wasps present remain 


\section{The Mason-Wasps}

impassive, do not interfere, a clear proof that the grub visited is in no peril. The stranger, in fact, retires with a soft, gliding motion. The chubby babe, a sort of india-rubber bag, resumes its original volume without having suffered any harm, as its appetite soon shows. A nurse offers it a mouthful, which it accepts with every sign of unimpaired vigour. As for the Volucellagrub, it licks its lips for a few moments after its own fashion, pushing its two fangs in and out; then, without further loss of time, it goes and repeats its probing elsewhere.

What it wants down there, at the bottom of the cells, behind the grubs, cannot be decided by direct observation; it must be guessed at. Since the visited larva remains intact, it is not prey that the Volucella's grub is after. Besides, if murder formed part of its plans, why dive to the bottom of the cell, instead of attacking the defenceless recluse straightway? It would be much easier to suck the patient's juices through the actual orifice of the cell. Instead of that, we see a dip, always a dip and never any other tactics.

Then what is there behind the Wasp-grub? Let us try to word all this as decently as we can. In spite of its exceeding cleanli304 


\section{The Volucella}

ness, the grub is not exempt from the physiological ills inseparable from the work of the stomach. Like all that eats, it has intestinal waste matter in regard to which its confinement compels it to behave with extreme discretion. Like so many other close-cabined larvæ of Wasps and Bees, it waits until the moment of the transformation to rid itself of its digestive refuse. Then, once and for all, it casts out the unclean accumulation whereof the pupa, that delicate, reborn organism, must not retain the least trace. This is found later, in any empty cell, in the form of a dark-purple plug. But, without waiting for this final purge, this lump, there are, from time to time, slight excretions of fluid, clear as water. We have only to keep a Wasp-grub in a little glass tube to recognize these occasional discharges. Well, I see nothing else to explain the action of the Volucella's grubs when they dip into the cells without wounding the larvæ. They are looking for this liquid, they provoke its emission. It represents to them a dainty which they enjoy over and above the more substantial fare provided by the corpses.

The Volucella, that sanitary inspector of the Vespian city, fulfils a double office: she gives the Wasp's children a wipe down; and 


\section{The Mason-Wasps}

she rids the Wasps'-nest of its dead. For this reason, she is peacefully received, as an assistant, when she enters the burrow to lay her eggs there; for this reason, her grub is tolerated, nay more, respected, in the very heart of the dwelling, where none might stray with impunity. I remember the brutal welcome accorded to the Saperda- and Hylotoma-larvæ when I place them upon a comb. Forthwith grabbed, bruised and riddled with stings, the poor wretches perish. It is quite a different matter with the offspring of the Volucella. They come and go as they please, poke about in the cells, elbow the inhabitants and remain unmolested. Let us give some instances of this clemency, which is very strange in the irascible Wasp.

For a couple of hours, I fix my attention on a Volucella-grub established in a cell, side by side with the Wasp-grub, the mistress of the house. The hind-quarters emerge, displaying their papillæ. Sometimes also the pointed fore-part, the head, appears, bending from side to side with sudden, Snakelike motions. The Wasps have just filled their crops at the honey-puddle; they are dispensing the rations, are very busily at work; and these things are taking place in broad daylight, on my table, by the window. 


\section{The Volucella}

As they pass from cell to cell, the nurses repeatedly brush against and stride across the Volucella-grub. There is no doubt that they see it. The intruder does not budge, or, if trodden on, retires inside, only to reappear the next moment. Some of the Wasps stop, bend their heads over the opening, seem to be making enquiries and then go off, without troubling further about the state of things. One of them does something even more remarkable: she tries to give a mouthful to the lawful occupant of the cell; but the larva, which is being squeezed by its visitor, has no appetite and refuses. Without the least sign of anxiety on behalf of the nurseling which she has seen in awkward company, the Wasp retires and goes to distribute her ration elsewhere.

In vain I prolong my examination: there is no fluster of any kind. The Volucella-grub is treated as a friend, or at least as a visitor that does not matter. There is no attempt to dislodge it, to worry it, to put it to flight. Nor does the grub seem to trouble greatly about those who come and go. Its tranquillity tells us that it feels at home.

Here is some further evidence: the grub has plunged, head downwards, into an empty cell, which is too small to contain the whole 


\section{The Mason-Wasps}

of it. Its hind-quarters stick out, very visibly. For long hours it remains motionless in this position. At every moment Wasps pass and repass close by. Three of them, at one time together, at another separately, come and nibble at the edges of the cell; they break off particles which they reduce to paste for a new piece of work.

The passers-by, intent upon their business, may not perceive the intruder; but these three certainly do. During their work of demolition, they touch the grub with their legs, their antennæ, their palpi; and yet none of them minds it. The fat grub, so easily recognized by its queer figure, is left alone; and this in broad daylight, where everybody can see it. What must it be when the profound darkness of the burrows protects the visitor with its mysteries!

I have been experimenting all along with big Volucella-grubs, coloured with the dirty red that comes with age. What effect will pure white produce? I sprinkle on the surface of the combs some larvæ that have lately left the egg. The tiny, snow-white grubs make for the nearest cells, go down into them, come out again and hunt about elsewhere. The Wasps peaceably let them go their way, as heedless of the little white 308 


\section{The Volucella}

invaders as of the big red ones. Sometimes, when it enters an occupied cell, the little creature is seized by the owner, the Waspgrub, which nabs it and turns it over and over in its mandibles. Is this a defensive bite? No, the Wasp-grub has merely blundered, taking its visitor for a proffered mouthful. There is no great harm done. Thanks to its litheness, the little grub escapes intact from the grip and continues its investigations.

It might occur to us to attribute this tolerance to some lack of penetration in the Wasps' vision. What follows will undeceive us: I place separately, in empty cells, a larva of the Scalary Saperda and a Volucellalarva, both of them white and selected so as not to fill the cell entirely. Their presence is revealed only by the paleness of the hindpart, which serves as a plug to the opening. A superficial examination would leave the nature of the recluse undecided. The Wasps make no mistake: they extirpate the Saperda-grub, kill it, throw it into the rubbish-pit; they leave the Volucella-grub in peace.

The two strangers are quite well recognized in the secrecy of the cells: one is the intruder that must be turned out; the other 


\section{The Mason-Wasps}

is the regular visitor that must be respected. Sight helps, for things take place in the daylight, under my cage; but the Wasps have other means of information in the dimness of the burrow. When I produce darkness by covering the apparatus with a screen, the murder of the trespassers is accomplished just the same. For so say the police-regulations of the Wasps'-nest: any stranger discovered must be slain and thrown on the midden.

To thwart this vigilance, the real enemies need to be masters of the art of stealthy immobility and cunning dissimulation. But there is no dissimulation about the Volucellagrub. It comes and goes, openly, wheresoever it will; it looks round amongst the Wasps for cells to suit it. What has it to make itself thus respected? Strength? Certainly not. It is a harmless creature, which the Wasp could rip open with a blow of her shears, while a touch of the sting would mean lightning death. It is a familiar guest, to whom no denizen of a Wasp'-nest bears ill-will. Why? Because it renders good service: so far from working mischief, it does the scavenging. Were it an enemy or merely an intruder, it would be exterminated; as a deserving assistant it is respected. 


\section{The Volucella}

Then what need is there for the Volucella to disguise herself as a Wasp? Any Fly, whether grey or motley, is admitted to the burrow directly she makes herself useful to the community. The mimicry of the Volucella, which was said to be one of the most conclusive cases, is, after all, a mere childish notion. Patient observation, continually face to face with facts, will have none of it and leaves it to the arm-chair naturalists, who are too prone to look at the animal world through the illusive mists of theory. 



\section{INDEX}

\section{A}

Agenia (see also the varieties below), 84-90, 222223,229

Agenia hyalipennis, $84-85$ Agenia punctum, 84-85, 89 Alpine Odynerus, 178-181 Ammonite, 239

Ammophilia (see Hairy Ammophila)

Ant, 246

Anthidium (see also $A$. bellicosum, Cotton-bee, Resin-bee), r 50, 219-220, 229

Anthidium bellicosum, ${ }^{178-}$ $18 \mathrm{r}$

Anthophora (see also the varieties below), 89,183 , 186-187

Anthophora parietina (see Anthophora of the Walls)

Anthophora personata (see Masked Anthophora)

Anthophora pilipes (see Hairy-footed Anthophora)

Anthophora of the Walls, $\mathbf{r} 68$

Attagenus pellis, 287

Attus, 90

Audouin, Jean Victor, 30, 44
Audubon, John James, 252, 255

Augustus, the Emperor, 170

B

Bacon-beetle (see Dermestes)

Bear, 134

Bee (see also Bumble-bee, Cotton-bee, Hive-bee, Mason-bee), 66-67, 69, $113,150,170,186,209$, 219

Bee-eating Wasp (see Philanthus)

Beetle (see also Sacred Beetle), 44, 176

Bembex, 18, 43, 91-92, 95, 99-100, 102

Black-bellied Tarantula (see Narbonne Lycosa)

Blanchard, Emile, 30

Bluebottle, $29 \mathrm{x}$

Bombyx mori (see Mulberry Bombyx)

Bower-bird, II-12

Bug, 74

Bulimulus radiatus, 178 , 180

Bumble-bee, 279, 28r

Bumble-bee Fly (see Volucella)

Butterfly, 14, 44, 117, 194195 


\section{Index}

C

Calicurgus (see Pompilus)

Capricorn, 89

Centipede, $54 n$

Century Co., v

Ceratite, 239

Cerceris, 103

Cetonia, 302

Chalicodoma (see Masonbee)

Chalicodoma parietina (see Mason-bee of the Walls) Chalicodoma rufescens (see Mason-bee of the Shrubs)

Chalicodoma rufitarsis (see Mason-bee of the Sheds)

Cheese-mite, 280

Chimney-swallow,

135 ,

141-1 42, 144-149

Chrysomela populi, 185, 192-200, 206-218

Cicada, 60, 89

Clubionus, 90

Coccinella (see Ladybird)

Common Ladybird (see Ladybird)

Common

Mouse

Mouse)

Common Snail (see Helix aspersa)

Common Wasp, I9r, 2403 I

Condillac, Étienne Bonnot de, Abbé de Mureaux, 112

Cotton-bee, $.73,12,186$

Crabro-wasp, 91-92, го3

Cricket (see also Italian Cricket), I 59-160

Cross Spider, 90-9r, 94

Cryptophagus, 287
D

Dart Moth (see Grey Worm)

Darwin, Charles Robert, 132

David, King, 135,138

Dermestes, 287

Diadem Epeira (see Cross Spider)

Dipper (see Water-ouzel)

Dog, 33-35, 48, 177, 243

Domestic Swallow (see Chimney Swallow)

Dryden, John, 136-137nn

Dufour, Jean Marie Léon, $30-32,35-36,42-45$

Dung-beetle (see Sacred Beetle)

E

Earth-worm, 89, 246

Edible Snail, r79-180

Eel, 119

Epeira (see also the varieties below), 90-9r, I60

Epeira adianta, 90

Epeira angulata, 90

Epeira diadema (see Cross Spider)

Epeira pallida, 90

Epeira scalaris, 90

Ephippiger, 211

Eristalis, 276-279

Eumenes (see also the varieties below), $\mathbf{1 - 2 9}, 56$, 57, 201, 203, 224-226, 229, 233

Eumenes Amadei, x, 4-27, $47,224-225$

Eumenes bipunctus, In

Eumenes dubius, In 


\section{Index}

Eumenes pomiformis, I, 4, $13-16,18-19,21,24-27$

Eumenes unguiculata, 225

\section{F}

Fabre, Mlle. Claire, the author's daughter, 184185, 205-209, 211

Fabre, Paul, the author's son, 240-24I, 243-244

Field-mouse, 152

Flesh-fly, 29I

Fly, 44, 99-100, 209, 253, 297-298

\section{G}

Garden Spider (see Epeira)

Geometrid Moth (see Looper)

Gnat, 84

Great Peacock Moth, xi7I28, 155

Greenbottle, 285-286, $29 x$

Grey Worm, 2, 2x, 43, 54, I 60,2 II

\section{$\mathrm{H}$}

Hairy Ammophila, 2n, 14, $17-18,21-22,43,54,103$, $x 60,204,211$

Hairy-footed Anthophora, I 68

Helix aspersa, 178

Helix nemoralis, 178

Helix strigata, II

Hen, 184

Hirundo rustica (see Chimney-swallow)

Hirundo urbica (see Window-swallow)
Hive-bee, 235-237, 276, 290-29I

Hoopoe, $34-35, \times 77$

Hornet, 248, 274, 276

House-fly, 297

House-martin (see Window-swallow)

House-spider, 92-93

House-swallow (see Window-swallow)

Humming-bird, 219

Hylotoma rosae, 280-28r, 306

\section{I}

Italian Cricket, 243

Iulus, 54

L

Ladybird, 185

Lalande, Joseph Jérôme Le Français de, 92

Languedocian Sphex, 2 II

Leaf-cutter (see Megachile)

Lepeletier de Saint-Fargeau, Amédée Comte, 30

Lepeletier de Saint-Fargeau, Félix, 3on

Lepeletier de Saint-Fargeau, Louis Michel, $30 \mathrm{~m}$

Lina populi (see Chrysomela p.)

Looper, 15

Lucilia (see Greenbottle)

Lycosa (see Narbonne Lycosa)

M

Mademoiselle Mori, author of, $2 n$ 


\section{Index}

Magpie, $\mathbf{2}$

Masked Anthophora, I68

Mason-bee (see also the varieties below), 5-6, 69, $78-79,83,87, \times 13, \times 15^{-}$ x17, 155, 159, 225, 246

Mason-bee of the Pebbles (see Mason-bee of the Walls)

Mason-bee of the Sheds,

II $1-113,163-166$

Mason-bee of the Shrubs, 75,167

Mason-bee of the Walls, $6,9,165,167,220-222$, 229, 233

Measuring - worm (see Looper)

Medium Wasp, 227-239, 247

Megachile, 16r-162, 182 , 186,246

Miall, Bernard, vi, $2 n$

Milesia fulminans, 295-296

Millipede, 287

Mole, 246, 259, 286

Moth (see also Great Peacock Moth), 14, 44, II7, 287

Mouse, 120, 287

Mulberry Bombyx, II8-119

Mule, 77-78

Myriapod, $54 n$

N

Narbonne Lycosa, 90, 94, 96

Nest-building Odynerus) 176-218

Nightingale, 289-29x

Noctua segetum (see Grey Worm)
Odynerus (see also the varieties below), 28-59, I 50, $x 76$

Odynerus alpestris (see Alpine Odynerus)

Odynerus nidulator (see Nest-building Odynerus)

Odynerus Reaumurii, 35

Odynerus reniformis, 3559, 177-178, 201-205

Odynerus spinipes, 35

Osmia (see also threehorned Osmia), 31-32, $69, \quad 150, \quad \times 68-169, \quad 182$, 186

Owl (see also Screechowl), 288

$\mathbf{P}$

Palarus, 102

Parrot, 12

Pelopxus, 31, 60-135, 137, $155,15^{8-160}, 165,222-$ $223,225,229,233$

Philanthus, 103

Plytonomus qariabilis, 44

Planorbis, 239

Plato, 239

Pliny, 34

Polistes, I9r, 236-237, 278279, 281, 294-295

Polydesma, 287

Pompilus, 90, 94, 96

Q

Quedius fulgidus, 286

R

Réaumur, René Antoine 


\section{Index}

Ferchault de, 29-32, 35, $37-42,44-45,5 x-53,184$, $2+1-242,259$

Ringed Calicurgus (see Pompilus)

Rodwell, Frances, vi

Rove-beetle (see Staphylinus)

\section{S}

Sacred Beetle, 227

Salamander, 65, 196

Saperda (see Scalary Saperda)

Saw-fly of the Rose (see Hylotoma rosae)

Scalary Saperda, 281, 306, 309

Scolia, 98, 103, 204

Screech-owl, 243

Segestria, 89

Shrew, 287

Silkworm (see Mulberry Bombyx)

Snail (see also Bulimilus, Edible Snail, Helix), II13, 168, 178, 237-239

Snake, 286

Solitary Wasp (see Odynerus)

Sophocles, 170

Sparrow, 135-1 54, 1 74, 275

Sphex (see also Languedocian Sphex), 18, 98, 103, 204

Spider (see also the varieties), 24, 81-82, 86, 89102, 106, 109-111, I13, 159-160, 222

Staphylinus 286-287

Stizus, 102
Swallow (see also Chimney-swallow, Windowswallow), $135^{-1} 54$

\section{T}

Tarantula (see Narbonne Lycosa)

Tachytes, 102

Tegenaria domestica (see House-spider)

Teixeira de Mattos, Alexander, $2 n, 4 n, 17 n, 30 n$, $89 n, 117 n, 227 n$

Theridion lugubre, 90

Three-horned Osmia, 167168, 170-175, 1 88-192

Tiberius, the Emperor, 170 Toad, 196

Turkey, 252, 255

Turnip Moth (see Grey

Worm)

\section{U}

Unwin, Mr. T. Fisher, vi

V

Vespa crabro (see Hornet)

Vespa media (see Median Wasp)

Vespa vulgaris (see Common Wasp)

Virgil, 136-1 37

Vitruvius, 3

Volucella zonaria, 285-286, 288-31 I

W

Wall-swallow (see Window-swallow) 


\section{Index}

Warbler, 289

Wasp (see also Common

Wasp, Median Wasp), $65-67,69,95$, 101-102, I 50, 170, 209, 219

Water-ouzel, 63
Weevil, 44

Window-swallow, $135,141-$ $143,145^{-146,147-149}$ Wolf, 134

Wood-louse, 287

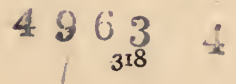




This book is DUE on the last date stamped below

131942

161942

16 19h-

31842

121942

JUL 5 19:S

AUL 9 19M

JOL 111246

d'1 231946

JUL 25

1904

APR 1 f 1947

APD 231847

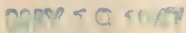

$31194 \%$

$P S: \infty 18 K 2$

R 24192

$\begin{array}{lll}Y & 1 & 1942\end{array}$

PMAY 15

AY \& 51942

JV 201942

UN 281946

3.1913

$m$ L-9-15m-7,'31

MAY 2 O 1947

WAY 20199

MAv $2 ? 1947$

Mar 281947

MAY 291947 ,

FEB 251952

RENEVAL ULI " J 1979

LD URL DISCHARGE-IMA:

11L JAN \& 4 ISBg 
568

Fabre -

V5FIIm The mason -wasps.

\section{MAY mang 194? Z: 1.}

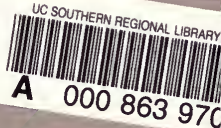

QI.

568

V5FIm 


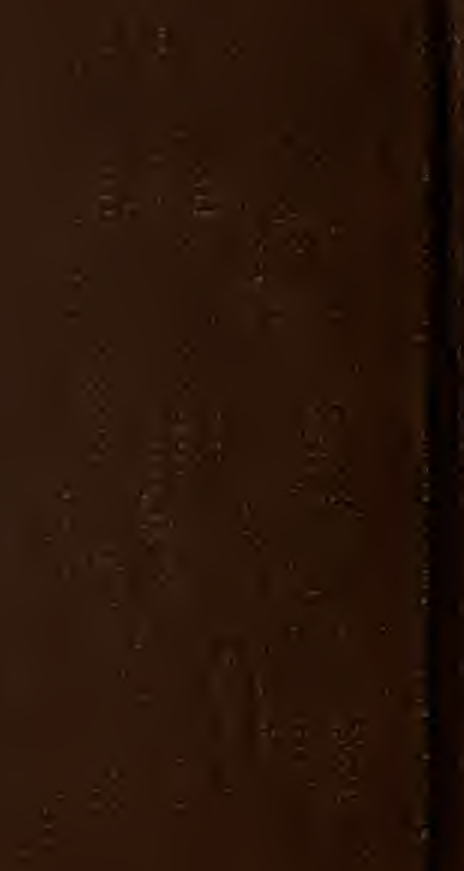

